In cooperation with the California State Water Resources Control Board

Review of Trace-Element Field-Blank Data Collected for the California Groundwater Ambient Monitoring and Assessment (GAMA) Program, May 2004-January 2008

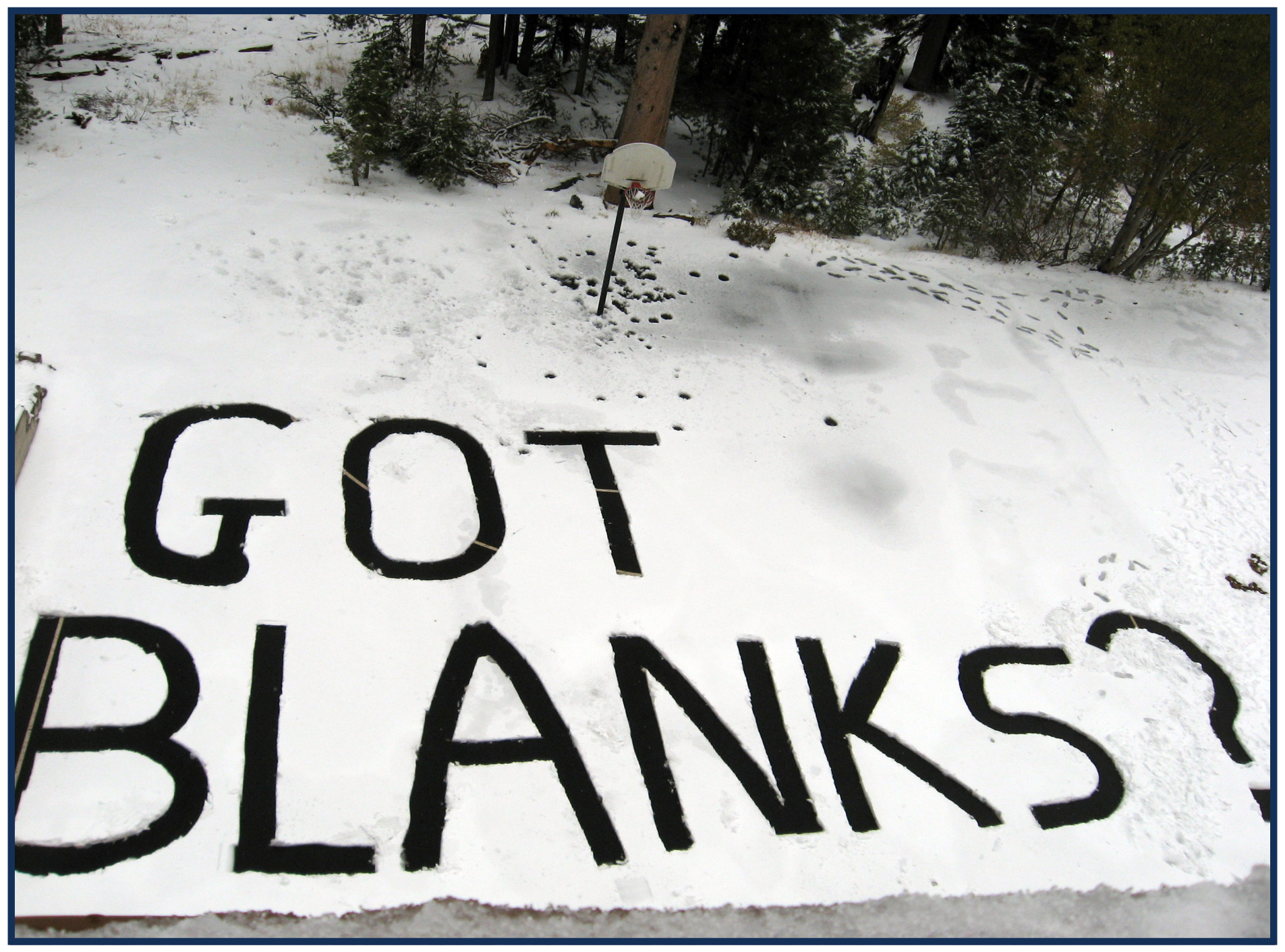

Scientific Investigations Report 2009-5220 
Cover: Snow art by Michael T. Land (U.S. Geological Survey). Photograph taken by Cathy Munday, U.S. Geological Survey, 2007. 


\section{Review of Trace-Element Field-Blank Data Collected for the California Groundwater Ambient Monitoring and Assessment (GAMA) Program, May 2004-January 2008}

By Lisa D. Olsen, Miranda S. Fram, and Kenneth Belitz

In cooperation with the California State Water Resources Control Board

Scientific Investigations Report 2009-5220 


\section{U.S. Department of the Interior \\ KEN SALAZAR, Secretary \\ U.S. Geological Survey \\ Marcia K. McNutt, Director}

U.S. Geological Survey, Reston, Virginia: 2010

For more information on the USGS - the Federal source for science about the Earth, its natural and living resources, natural hazards, and the environment, visit http://www.usgs.gov or call 1-888-ASK-USGS

For an overview of USGS information products, including maps, imagery, and publications, visit http://www.usgs.gov/pubprod

To order this and other USGS information products, visit http://store.usgs.gov

Any use of trade, product, or firm names is for descriptive purposes only and does not imply endorsement by the U.S. Government.

Although this report is in the public domain, permission must be secured from the individual copyright owners to reproduce any copyrighted materials contained within this report.

Suggested citation:

Olsen, L.D., Fram, M.S., and Belitz, Kenneth, 2010, Review of trace-element field-blank data collected for the California Groundwater Ambient Monitoring and Assessment (GAMA) Program, May 2004-January 2008: U.S. Geological Survey Scientific Investigations Report 2009-5220, 47 p. 


\section{Contents}

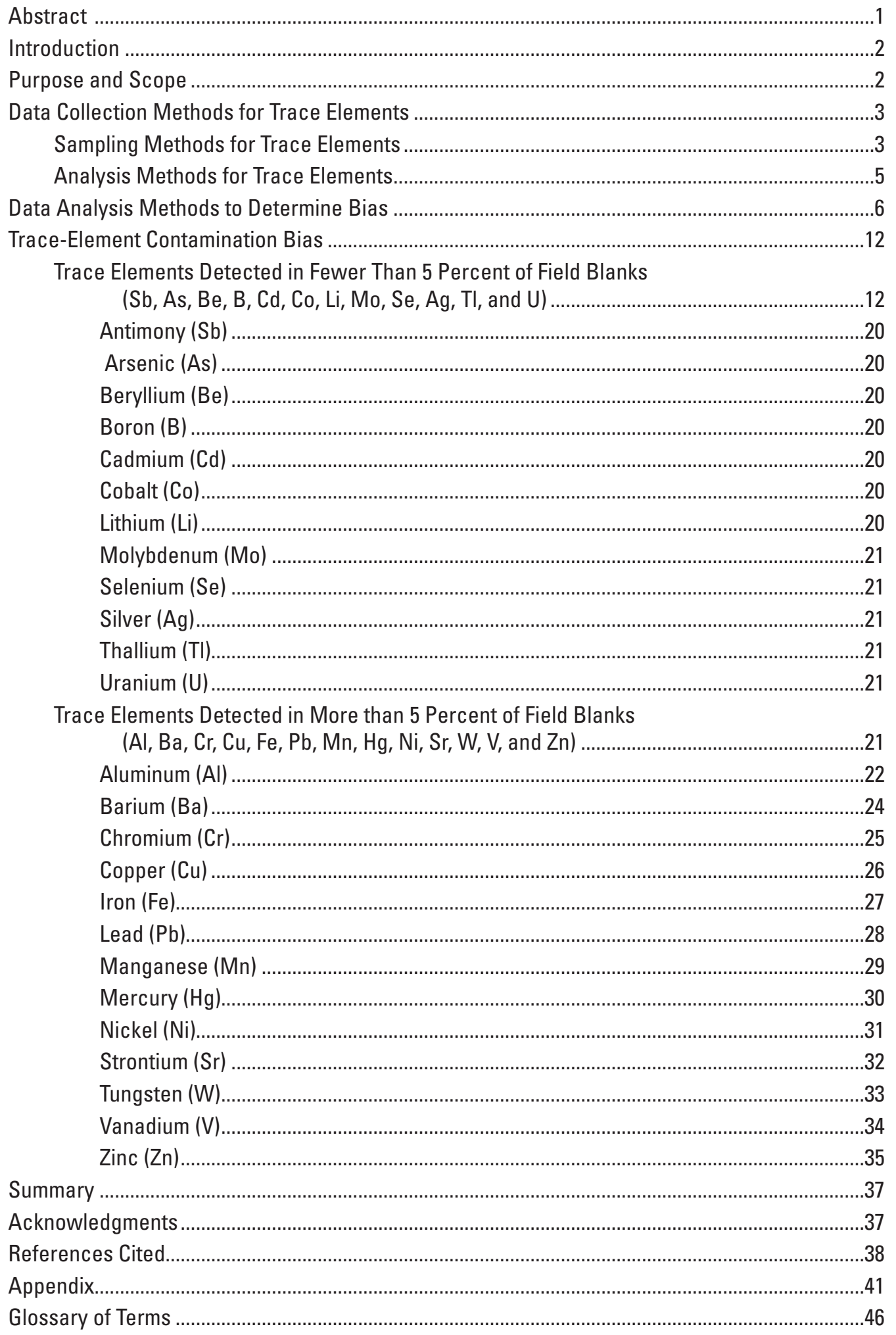




\section{Figures}

1. Map showing wells sampled for analysis of trace elements for the first 20 study units of the California Groundwater Ambient Monitoring and Assessment (GAMA) Priority Basins Project, May 2004 through January 2008.

2-18. Graphs showing:

2. Three possible relations between the BD-90/90 concentration and the LRL, the LT-MDL, and the SRL, and the resulting reporting notation for environmental samples

3. Trace-element concentrations and BD-90/90 concentrations for constituents detected in fewer than 5 percent of the field blanks collected from May 2004 through January 2008 for $A$. antimony (Sb), B. arsenic (As), C. beryllium (Be), D. boron (B), E. cadmium (Cd), F. cobalt (Co), G. lithium (Li), H. molybdenum (Mo), I. selenium (Se), J. silver (Ag), K. thallium (TI), L. uranium (U)

4. Aluminum (Al) concentrations in field blanks collected from May 2004 through January 2008, plotted in time-series with the BD-90/90 concentration

5. Aluminum (Al) concentrations in field blanks paired with their corresponding groundwater samples collected from May 2004 through January 2008

6. Barium $(\mathrm{Ba})$ concentrations in field blanks collected from May 2004 through January 2008, plotted in time-series with the BD-90/90 concentration

7. Chromium $(\mathrm{Cr})$ concentrations in field blanks collected from May 2004 through January 2008, plotted in time-series with the BD-90/90 concentration

8. Copper (Cu) concentrations in field blanks collected from May 2004 through January 2008, plotted in time-series with the BD-90/90 concentration

9. Iron (Fe) concentrations in field blanks collected from May 2004 through January 2008, plotted in time-series with the BD-90/90 concentration .27

10. Lead $(\mathrm{Pb})$ concentrations in field blanks collected from May 2004 through January 2008, plotted in time-series with the BD-90/90 concentration .28

11. Manganese $(\mathrm{Mn})$ concentrations in field blanks collected from May 2004 through January 2008, plotted in time-series with the BD-90/90 concentration

12. Mercury $(\mathrm{Hg})$ concentrations in field blanks collected from May 2004 through January 2008, plotted in time-series with the BD-90/90 concentration .30

13. Nickel (Ni) concentrations in field blanks collected from May 2004 through January 2008, plotted in time-series with the BD-90/90 concentration .31

14. Strontium (Sr) concentrations in field blanks collected from May 2004 through January 2008, plotted in time-series with the BD-90/90 concentration

15. Tungsten (W) concentrations in field blanks collected from May 2004 through January 2008, plotted in time-series with the BD-90/90 concentration 33

16. Vanadium (V) concentrations in field blanks collected from May 2004 through January 2008, plotted in time-series with the BD-90/90 concentration .34

17. Zinc $(\mathrm{Zn})$ concentrations in field blanks collected from May 2004 through January 2008, plotted in time-series with the BD-90/90 concentration .35

18. Zinc $(\mathrm{Zn})$ concentrations in groundwater samples and field blanks collected from May 2004 through January 2008, plotted in time-series with the SRL and SMCL-CA 


\section{Tables}

1. Trace elements collected for the Groundwater Ambient Monitoring and Assessment (GAMA) program, comparative thresholds, and reporting information for the U.S. Geological Survey National Water Quality Laboratory, May 2004 through January 2008.

2. Detection frequencies, BD-90/90 concentrations, and study reporting levels (SRL) determined from field-blank data for samples analyzed for trace elements by the U.S. Geological Survey National Water Quality Laboratory and collected for the Groundwater Ambient Monitoring and Assessment (GAMA) program, May 2004 through January 2008

3. Assessment of blind blanks submitted by the U.S. Geological Survey (USGS) Branch of Quality Systems (BOS) Blind Blank Project and analyzed for trace elements by the USGS National Water Quality Laboratory, including laboratory reporting levels and BD-90/90 concentrations, May 2004 through January 2008

Appendix Table A1. Raw results of quality-control analyses for certification of universal blank water and inorganic blank water provided by the U.S. Geological Survey National Water Quality Laboratory and used by the Groundwater Ambient Monitoring and Assessment (GAMA) program from May 2004 through January 2008. 


\section{Abbreviations and Acronyms}

$A B$

AL-US

BD-90/90

CVAFS

CAS

$\mathrm{E}$

GAMA

HAL-US

ICP-AES

ICP-MS

LRL

LT-MDL

MCL-CA

MCL-US

MDL

$\mathrm{N}$

na

NL-CA

OC

SMCL-CA

SRL

US

V

$<$

$\leq$

Organizations

BOS

$\mathrm{CDPH}$

CDWR

USEPA

LLNL

NAWQA

NWOL

SWRCB

USEPA

USGS

Assembly Bill (through the California State Assembly)

Action Level (U.S. Environmental Protection Agency [USEPA])

90th percentile concentration determined using binomial distribution with a confidence level that is 90 percent or greater

cold-vapor atomic-fluorescence spectrometry

Chemical Abstract Service (American Chemical Society)

estimated or having a higher degree of uncertainty

Groundwater Ambient Monitoring and Assessment (program)

lifetime health advisory level (USEPA)

inductively coupled plasma with atomic-emission spectroscopy

inductively coupled plasma with mass spectrometry

laboratory reporting level

long-term method detection level

maximum contaminant level (California Department of Public Health [CDPH])

maximum contaminant level (USEPA)

method detection limit

Normal (1-gram-equivalent per liter of solution)

not available or not analyzed

California notification level (CDPH)

quality control

secondary maximum contaminant level (CDPH)

study reporting level

United States

analyte was detected in associated blanks; therefore, value was excluded from the dataset of groundwater quality results

less than

less than or equal to

Branch of Quality Systems (USGS Office of Water Quality)

California Department of Public Health

California Department of Water Resources

U.S. Environmental Protection Agency

Lawrence Livermore National Laboratory

National Water Quality Assessment program (USGS)

National Water Quality Laboratory (USGS)

State Water Resources Control Board (California)

U.S. Environmental Protection Agency

U. S. Geological Survey

\section{Units of Measure}

$\mathrm{ft} \quad$ foot (feet)

L liter

mi mile

$\mathrm{mL} \quad$ milliliter

$\mu \mathrm{g} / \mathrm{L} \quad$ micrograms per liter (parts per billion)

$\mu \mathrm{m} \quad$ micrometer 


\section{Notes}

Concentrations of chemical constituents in water are given in micrograms per liter ( $\mu \mathrm{g} / \mathrm{L})$.

Micrograms per liter is equivalent to parts per billion (ppb).

This report contains CAS Registry Numbers ${ }^{\circledR}$, which is a Registered Trademark of the American Chemical Society. CAS recommends the verification of the CAS Registry Numbers through CAS Client Services ${ }^{\mathrm{SM}}$. 
This page intentionally left blank. 


\title{
Review of Trace-Element Field-Blank Data Collected for the California Groundwater Ambient Monitoring and Assessment (GAMA) Program, May 2004-January 2008
}

\author{
By Lisa D. Olsen, Miranda S. Fram, and Kenneth Belitz
}

\section{Abstract}

Trace-element quality-control samples (for example, source-solution blanks, field blanks, and field replicates) were collected as part of a statewide investigation of groundwater quality in California, known as the Priority Basins Project of the Groundwater Ambient Monitoring and Assessment (GAMA) Program. The GAMA Priority Basins Project is being conducted by the U.S. Geological Survey (USGS) in cooperation with the California State Water Resources Control Board (SWRCB) to assess and monitor the quality of groundwater resources used for drinking-water supply and to improve public knowledge of groundwater quality in California.

Trace-element field blanks were collected to evaluate potential bias in the corresponding environmental data. Bias in the environmental data could be related to contamination in the field from contact between groundwater and sampling equipment or other contaminant sources, or to contamination during processing, shipping, or analyzing the samples. Bias can affect the interpretation of environmental data, particularly if any constituents are present solely as a result of extrinsic contamination that would have otherwise been absent from the groundwater that was sampled. Field blanks were collected, analyzed, and reviewed to identify and quantify extrinsic contamination bias. Data derived from source-solution blanks and laboratory quality-control samples also were considered in evaluating potential contamination bias.

Eighty-six field-blank samples collected from May 2004 to January 2008 were analyzed for the concentrations of 25 trace elements. Results from these field blanks were used to interpret the data for the 816 samples of untreated groundwater collected over the same period. Constituents analyzed were aluminum ( $\mathrm{Al})$, antimony $(\mathrm{Sb})$, arsenic ( $\mathrm{As})$, barium $(\mathrm{Ba})$, beryllium $(\mathrm{Be})$, boron $(\mathrm{B})$, cadmium $(\mathrm{Cd})$, chromium $(\mathrm{Cr})$, cobalt $(\mathrm{Co})$, copper $(\mathrm{Cu})$, iron $(\mathrm{Fe})$, lead $(\mathrm{Pb})$, lithium $(\mathrm{Li})$, manganese $(\mathrm{Mn})$, mercury $(\mathrm{Hg})$, molybdenum $(\mathrm{Mo})$, nickel $(\mathrm{Ni})$, selenium $(\mathrm{Se})$, silver $(\mathrm{Ag})$, strontium $(\mathrm{Sr})$, thallium $(\mathrm{Tl})$, tungsten $(\mathrm{W})$, uranium $(\mathrm{U})$, vanadium $(\mathrm{V})$, and zinc $(\mathrm{Zn})$. The detection frequency and the $90^{\text {th }}$ percentile concentration at greater than 90 percent confidence were determined from the field-blank data for each trace element, and these results were compared to each constituent's long-term method detection level (LT-MDL) to determine whether a study reporting level (SRL) was necessary to ensure that no more than 10 percent of the detections in groundwater samples could be attributed solely to contamination bias.

Only two of the trace elements analyzed, Li and Se, had zero detections in the 86 field blanks. Ten other trace elements ( $\mathrm{Sb}, \mathrm{As}, \mathrm{Be}, \mathrm{B}, \mathrm{Cd}, \mathrm{Co}, \mathrm{Mo}, \mathrm{Ag}, \mathrm{Tl}$, and $\mathrm{U}$ ) were detected in fewer than 5 percent of the field blanks. The field-blank results for these constituents did not necessitate establishing SRLs. Of the 13 constituents that were detected in more than 5 percent of the field blanks, six (Al, Ba, Cr, Mn, Hg, and V) had field-blank results that indicated a need for SRLs that were at or below the highest laboratory reporting levels (LRL) used during the sampling period; these SRLs were needed for concentrations between the LT-MDLs and LRLs. The other seven constituents with detection frequencies above 5 percent $(\mathrm{Cu}$, $\mathrm{Fe}, \mathrm{Pb}, \mathrm{Ni}, \mathrm{Sr}, \mathrm{W}$, and $\mathrm{Zn}$ ) had field-blank results that necessitated SRLs greater than the highest LRLs used during the study period. SRLs for these seven constituents, each set at the $90^{\text {th }}$ percentile of their concentrations in the field blanks, were at least an order of magnitude below the regulatory thresholds established for drinking water for health or aesthetic purposes; therefore, reporting values below the SRLs as less than or equal to $(\leq)$ the measured value would not prevent the identification of values greater than the drinking-water thresholds. The SRLs and drinking-water thresholds, respectively, for these 7 trace elements are $\mathrm{Cu}(1.7 \mu \mathrm{g} / \mathrm{L}$ and $1,300 \mu \mathrm{g} / \mathrm{L})$, $\mathrm{Fe}(6 \mu \mathrm{g} / \mathrm{L}$ and $300 \mu \mathrm{g} / \mathrm{L}), \mathrm{Pb}(0.65 \mu \mathrm{g} / \mathrm{L}$ and $15 \mu \mathrm{g} / \mathrm{L}), \mathrm{Ni}$ $(0.36 \mu \mathrm{g} / \mathrm{L}$ and $100 \mu \mathrm{g} / \mathrm{L}), \operatorname{Sr}(0.99 \mu \mathrm{g} / \mathrm{L}$ and $4,000 \mu \mathrm{g} / \mathrm{L}), \mathrm{W}$ $(0.11 \mu \mathrm{g} / \mathrm{L}$ and none $)$, and $\mathrm{Zn}(4.8 \mu \mathrm{g} / \mathrm{L}$ and $5,000 \mu \mathrm{g} / \mathrm{L})$. The primary sources of contamination inferred from this review include specific lots of blank water used for the field blanks, and the equipment or the processes used in the field to collect the samples. 


\section{Introduction}

Groundwater makes up nearly half of the water used for public supply in California (Hutson and others, 2004). The California State Water Resources Control Board (SWRCB), in collaboration with the U.S. Geological Survey (USGS) and Lawrence Livermore National Laboratory (LLNL), initiated the Groundwater Ambient Monitoring and Assessment (GAMA) Program (http://www.swrcb.ca.gov/gama) to assess the quality of ambient groundwater in aquifers used for public supply and to establish a baseline groundwater quality monitoring program. The GAMA Program consists of three projects: the Priority Basin Project, conducted by the USGS (http://ca.water.usgs.gov/gama); the Voluntary Domestic Well Project, conducted by the SWRCB; and Special Studies, conducted by LLNL.

The GAMA Program's Priority Basins Project is a statewide assessment of groundwater quality designed to help identify and better understand risks to groundwater resources and to increase the availability of groundwater quality information to the public. The USGS, in collaboration with the SWRCB, developed the monitoring plan for the project (Belitz and others, 2003; California State Water Resources Control Board, 2003). California's groundwater basins were prioritized on the basis of the number of public drinking-water supply wells and secondarily on other factors. The 116 priority basins, representing 95 percent of the wells in basins, were grouped into 35 study units to be sampled between 2004 and 2010 . Samples of untreated groundwater were collected from a set of randomized, spatially distributed wells that represent the portion of the aquifer used for public drinking-water supply (grid wells) and from additional wells selected to support better understanding of factors that affect groundwater quality (understanding wells).

Eight hundred and sixteen groundwater samples and associated quality-control (QC) samples, collected in the first 20 study units from May 2004 through January 2008, were analyzed for 25 trace elements. Field QC samples consisted of 86 field blanks and 15 source-solution blanks. Trace elements analyzed were as follows:

$\begin{array}{lll}\text { aluminum }(\mathrm{Al}) & \text { antimony }(\mathrm{Sb}) & \text { arsenic }(\mathrm{As}) \\ \text { barium }(\mathrm{Ba}) & \text { beryllium }(\mathrm{Be}) & \text { boron }(\mathrm{B}) \\ \text { cadmium }(\mathrm{Cd}) & \text { chromium }(\mathrm{Cr}) & \text { cobalt }(\mathrm{Co}) \\ \text { copper }(\mathrm{Cu}) & \text { iron }(\mathrm{Fe}) & \text { lead }(\mathrm{Pb}) \\ \text { lithium }(\mathrm{Li}) & \text { manganese }(\mathrm{Mn}) & \text { mercury }(\mathrm{Hg}) \\ \text { molybdenum }(\mathrm{Mo}) & \text { nickel }(\mathrm{Ni}) & \text { selenium }(\mathrm{Se}) \\ \text { silver }(\mathrm{Ag}) & \text { strontium }(\mathrm{Sr}) & \text { thallium }(\mathrm{Tl}) \\ \text { tungsten }(\mathrm{W}) & \text { uranium }(\mathrm{U}) & \text { vanadium }(\mathrm{V})\end{array}$

zinc $(\mathrm{Zn})$

Field-blank results for trace elements were reviewed to determine potential bias in the environmental data, which could have resulted from the groundwater coming into contact with contaminants on equipment surfaces or with other sources in the field, or from contamination during processing, shipment, or analysis of the samples. Field-blank data were evaluated in conjunction with the results of source-solution blanks and third-party laboratory blanks to aid in identifying or ruling out possible sources of extrinsic contamination (contamination originating from a process or source external to the medium being sampled).

For constituents that were detected in the field blanks, bias was quantified by calculating the detection frequency for the field blanks and the $90^{\text {th }}$ percentile concentration at 90 percent confidence or higher in the field blanks, using the binomial distribution. To minimize the effects of bias on the subsequent interpretation of groundwater sample results, these constituents were each assigned a raised study reporting level (SRL) at their respective $90^{\text {th }}$ percentile concentrations to ensure that no more than 10 percent of the detections in the groundwater samples could be attributed to the extrinsic contamination identified from the field blanks. One option for using these SRLs as a measure of bias would have been to subtract them from the groundwater sample results; this approach was not used because the SRLs did not represent the central tendency of the contamination bias, since the median concentrations were below LT-MDLs for all trace elements in field blanks. Instead, the SRLs were used as a raised reporting level below which concentrations would be remarked as less than or equal to $(\leq)$ the reported value to indicate results that could be affected by contamination bias.

\section{Purpose and Scope}

This report describes the methodology and results of an evaluation of data derived from the trace-element field blanks that were collected along with groundwater samples from May 2004 through January 2008. This evaluation determined the frequency and magnitude of trace-element contamination bias throughout this period using results from analyses of the field blanks along with additional field and laboratory QC information. The use of the binomial distribution to determine the 90th percentile concentration in the field blanks (with greater than 90 percent confidence) for each constituent is described. For each constituent for which the 90th-percentile value was a detection, this report explains how an SRL was established and provides guidelines for reporting groundwater sample results that are below the SRL. Potential sources of contamination to the field blanks and environmental samples are discussed in the context of the results of blank-water certificates of analysis, field blanks, source-solution blanks, and third-party laboratory blanks. Although it was beyond the scope of this report to identify all specific sources of contamination, it was usually possible to estimate the relative contributions from the blank water and from field and laboratory processes. 
The results of this evaluation are compared with drinking-water thresholds established by the U.S. Environmental Protection Agency (USEPA) and the California Department of Public Health (CDPH) to protect human health or to limit the presence of constituents that could affect the aesthetic or technical qualities of drinking water, such as taste, odor, scaling, or staining. This comparison was made to verify that using SRLs for reporting the results for certain constituents would not interfere with identifying environmental sample results near or above any thresholds, which is an objective of the GAMA Priority Basins Project. Although these drinking-water thresholds are used for comparison purposes, they do not apply to the groundwater samples collected for this project, which were used to characterize the quality of untreated groundwater resources, not the treated drinking water delivered to consumers by water purveyors. Details of the individual groundwater studies through which the data were collected for this evaluation are not presented here, but are available in reports by Wright and others (2005), Bennett and others (2006), Kulongoski and others (2006), Fram and Belitz (2007), Kulongoski and Belitz (2007), Burton and Belitz (2008), Dawson and others (2008), Ferrari and others (2008), Land and Belitz (2008), Landon and Belitz (2008), Mathany and others (2008), Schmitt and others (2008), Shelton and others (2008), Bennett and others (2009), Densmore and others (2009), Fram and others (2009), Goldrath and others (2009), Kent and others (2009), Montrella and Belitz (2009), and Ray and others (2009).

\section{Data Collection Methods for Trace Elements}

Because the purpose of this evaluation of trace-element field-blank data is to characterize potential bias to the corresponding groundwater samples, the data collection process will be described for the groundwater samples as well as for the field and source-solution blanks. Groundwater and QC samples were collected for trace-element analyses from May 2004 through January 2008 from 816 wells in 20 study units (fig. 1) distributed throughout California in ten hydrogeologic provinces delineated by Belitz and others (2003). Land-use ranged from natural (undeveloped) to intensive agriculture or predominantly urban. Most wells selected for the GAMA Priority Basin Project are listed in the CDPH database (municipal and community drinking-water supply wells). Some domestic, irrigation, industrial, and monitoring wells also were sampled. The project focuses on the part of the aquifer systems defined by the depth intervals over which the drinking-water supply wells in the CDPH database for each study unit are perforated (termed the "primary aquifer"). Approximately 80 percent of the wells were selected using a spatially distributed, randomized grid-based approach to provide a statistical representation of the primary aquifer or aquifers in each study unit. The remaining wells were selected to support the project component that focuses on understanding the natural and human factors affecting water quality in each study unit. The development of the well network for monitoring and assessment is described further by Belitz and others (2003). Groundwater sample data, along with assessments of the corresponding QC data, are given for their respective study units in the reports listed in the Purpose and Scope section.

\section{Sampling Methods for Trace Elements}

Groundwater samples to be used for trace-element analysis were collected in accordance with the protocols established by the USGS National Water Quality Assessment (NAWQA) program (Koterba and others, 1995) and the USGS National Field Manual (U.S. Geological Survey, variously dated). These protocols ensure that a sample that is representative of the groundwater in the aquifer is collected from each well and that samples are handled in a consistent way that minimizes the potential for extrinsic contamination of samples. Prior to collecting samples, each well was pumped continuously to purge at least 3 casing-volumes of water from the well, until field parameters (water temperature, specific conductance, $\mathrm{pH}$, and dissolved oxygen) were stable (Wilde, 2006). Wells were sampled using Teflon tubing with stainless-steel fittings attached to a sampling point (hose bib) on the well discharge pipe as close to the well as possible. At some wells, additional fittings made of brass, steel, or stainless steel had to be used to connect to the well. The sampling point was located upstream of any well-head treatment system or water storage tank, except for infrequent cases in which this was not possible. If a chlorinating system was attached to the well, the chlorinator was shut off prior to purging and sampling the well, in order to clear all chlorine out of the system. Samples were either collected at the well head using a short length of Teflon tubing attached to a stainless-steel connector or from within an enclosed chamber inside a mobile laboratory that was linked to the well head by a 10- to 50-foot length of Teflon tubing with stainless-steel connectors (Lane and others, 2003). Monitoring wells usually were sampled by using a pre-cleaned stainless-steel Grundfos ${ }^{\circledR}$ submersible pump with a Teflon discharge line. All fittings and lengths of tubing were cleaned thoroughly between sampling events with, at minimum, non-phosphate laboratory detergent (for example, Liquinox ${ }^{\mathrm{TM}}$ ) followed by thorough rinses with tap water, dilute acid-solution (non-metal parts only), and finally, universal blank water or inorganic blank water (described in the next section) (Wilde, 2004). 


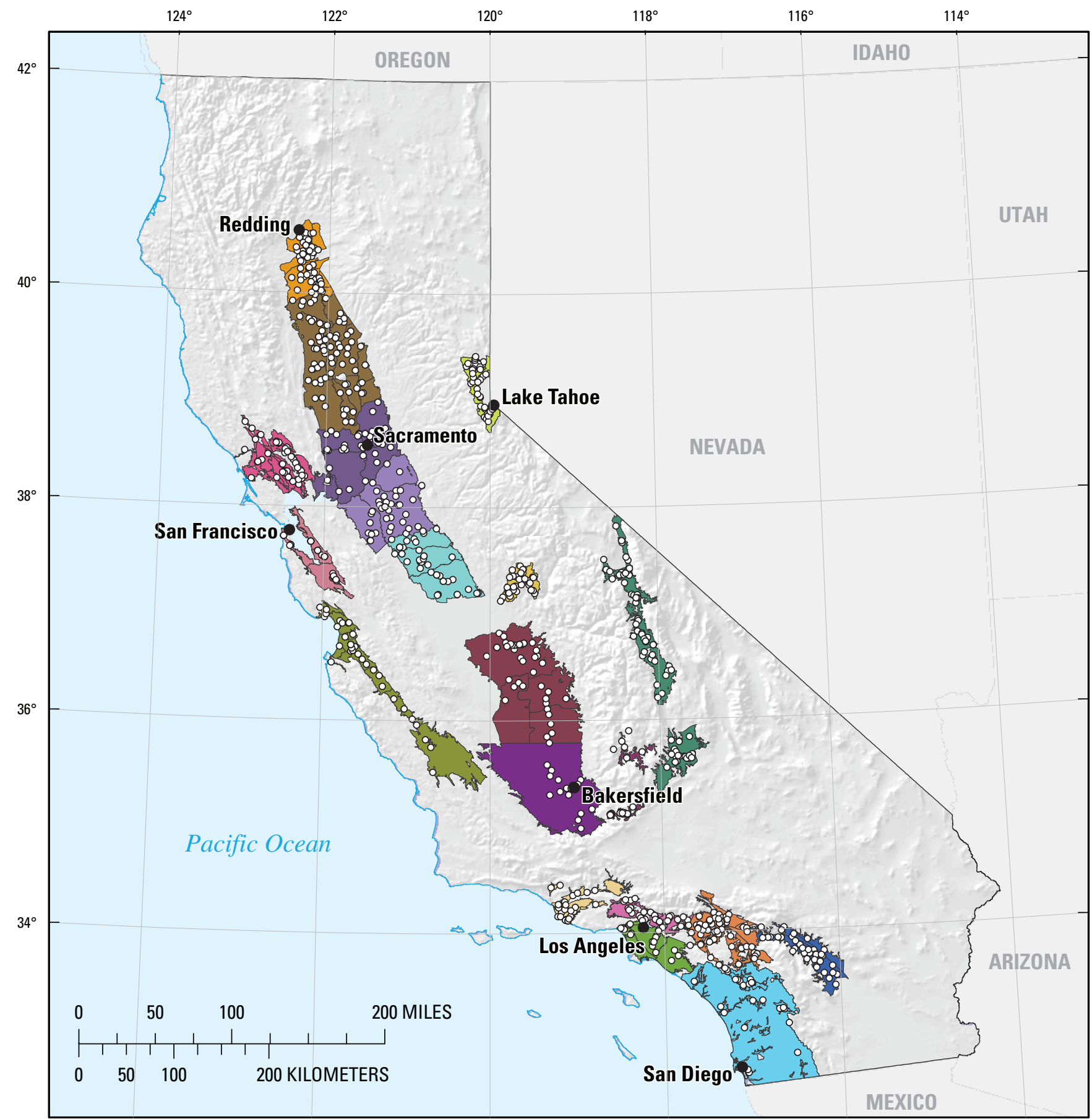

Shaded relief derived from U.S. Geological Survey National Elevation Dataset, 2006,

Albers Equal Area Conic Projection

Figure 1. Wells sampled for analysis of trace elements for the first 20 study units of the California Groundwater Ambient Monitoring and Assessment (GAMA) Priority Basins Project, May 2004 through January 2008. 
Groundwater samples collected to be analyzed for trace elements were filtered using a 0.45 -micrometer pore-size Whatman capsule filters that had been prerinsed with deionized water. Groundwater samples were collected into either acid-rinsed $250-\mathrm{mL}$ polyethylene bottles that had been prerinsed with deionized water and then native water, or (for $\mathrm{Hg}$ analysis) into $250-\mathrm{mL}$ glass bottles that had been acid-rinsed, as described by Wilde and others (2004). Samples were then preserved with certified 7.5-N nitric acid to a $\mathrm{pH}$ of 2 or less or with 6-N hydrochloric acid to a $\mathrm{pH}$ of 2 or less (for $\mathrm{Hg}$ analysis), as described by Wilde and others (2004). Replicate groundwater samples were collected sequentially at approximately 10 percent of the wells ( 79 wells) to assess variability that may result from collecting, transporting, and analyzing samples.

Field blanks and source-solution blanks to be analyzed for trace elements were collected using "universal blank water" (UBW) generally before June 2006, or "inorganic blank water" (IBW) generally after June 2006. Both types of blank water were analyzed shortly after purchase or after being purged with nitrogen (UBW only) by the USGS National Water Quality Laboratory (NWQL) and certified to be free from the analytes of interest. Following sample collection during spring 2006, it was discovered that during storage, one lot of UBW (NWIS-I Lot No. 80501) had acquired concentrations of aluminum, barium, chromium, iron, manganese, and strontium that were above the long-term method detection limits (LT-MDL). The hypothesized source was the leaching of these trace elements from the amber glass bottles used to contain the water following purchase and analysis by the USGS (written commun.: USGS NWQL Rapi-Note 06-008, April 2006; USGS NWQL Rapi-Note 06-022, June 2006; James A. Lewis, August 2008). This problem could not be easily corrected, and the use of UBW was subsequently discontinued. Similarly, shortly after shipment and initial use, the IBW (NWIS-I Lot No. 80703) used during October 2007 was found to contain elevated concentrations of boron (USGS Office of Water Quality Information Note 2008.01, written commun, October 2007). Certificates of analysis for UBW and IBW used during the study period are presented in the appendix.

Field blanks were collected at approximately 10 percent of the wells ( 86 of 816 wells) to determine if equipment or procedures used in the field or laboratory introduced contamination to the samples. Field blanks were collected at selected well sites by pumping at least 4 to $12 \mathrm{~L}$ (liter) of blank water through the sample collection equipment (fittings and tubing), to simulate the well-purging step, and then pumping additional blank water through the equipment to be collected as blank samples, following the same protocols as were used for the groundwater samples, including filtration and preservation. The minimum volume of blank water needed for the final rinse before collecting each field blank was calculated on the basis of tubing volume as described in the USGS National Field Manual (Wilde, 2004). For some shallow monitoring wells for which relatively short sampling lines were used, the blank water was poured, rather than pumped, through the equipment.
Source-solution blanks were collected less frequently (15 of 816 wells) to verify the NWQL certifications that the blank water used for the field blanks was free of analytes of interest. Source-solution blanks were collected by pouring blank water directly into sample containers that were then preserved, stored, and shipped in the same manner as the groundwater samples.

\section{Analysis Methods for Trace Elements}

Groundwater and QC samples collected for trace-element analysis were shipped within a few days of collection to the USGS National Water Quality Laboratory in Denver, Colorado. Samples were analyzed using a combination of methods, including inductively coupled plasma with mass spectrometry (ICP-MS), collision-cell inductively coupled plasma with mass spectrometry (cICP-MS), inductively coupled plasma with atomic-emission spectroscopy (ICP-AES), and cold-vapor atomic-fluorescence spectrometry (CVAFS), as described by Fishman (1993), Garbarino (1999), Garbarino and Damrau (2001), and Garbarino and others (2006). These samples were analyzed as part of USGS NWQL Schedule 1948 or Schedule 2710.

The quality-assurance program followed by the NWQL is described by Maloney (2005) and Pirkey and Glodt (1998). Laboratory QC samples, including laboratory method blanks, continuing calibration verification checks, reagent spikes, certified standard reference materials, and external blind proficiency samples, are analyzed regularly. The NWQL maintains certification by the National Environmental Laboratory Accreditation Program (NELAP) and other certifications (http://nwql.usgs.gov/Public/lab_cert.shtml). In addition, the Branch of Quality Systems (BQS) within the USGS Office of Water Quality maintains independent oversight of quality assurance at the NWQL and coordinates blind testing of blanks and reference samples through the Blind Blank Project and Inorganic Blind Sample Project (Ludtke and Woodworth, 1997), which can be accessed through http://bqs.usgs.gov/. The BQS Blind Blank Project is the source of the third-party laboratory blank data used for the evaluation in this report.

The USGS NWQL uses the long-term method-detection level (LT-MDL) and the laboratory reporting level (LRL) as thresholds for reporting analytical results. The USEPA method detection limit (MDL) is the minimum concentration of a substance that can be measured and reported with 99 percent confidence that the concentration is greater than zero; at the MDL, there is less than 1 percent chance of a false positive (U.S. Environmental Protection Agency, 2002). The MDL is determined by analyzing at least seven low-level spikes over a relatively short period. In place of the MDL, the NWQL uses the LT-MDL, which is derived from the standard deviation of at least 24 low-level spike or blank measurements made over an extended period of time, as described by Childress and others (1999). Low-level spikes and blanks are monitored throughout each year, and LT-MDLs are reevaluated no less 
frequently than annually and are updated accordingly. The LRL is used to control false-negative error and is usually set at two times the LT-MDL for each constituent. The probability of reporting a false negative for a sample that contains a concentration of a constituent greater than or equal to the LRL is predicted to be less than or equal to 1 percent (Childress and others, 1999).

For trace elements, the NWQL reports values below the LT-MDL as nondetections, designated with a " $<$ " code. These values are not statistically different from zero. Values below the LT-MDL are reported as $<$ LRL to indicate that the true concentration might be as large as twice the LT-MDL. Values measured between the LT-MDL and LRL are reported as "estimated" concentrations, designated with an "E" code. E-coded values have a high likelihood of being greater than zero, but can have a high degree of uncertainty in the precise concentration. ("E" is defined for the USGS National Water Information System [NWIS] as "estimated or having a higher degree of uncertainty.") LRLs and USGS test IDs (consisting of the parameter code and method code) for the trace elements analyzed for the GAMA Priority Basins Project during May 2004 through January 2008 are given in table 1; the corresponding LT-MDLs can be determined by dividing the respective LRLs by two.

\section{Data Analysis Methods to Determine Bias}

Contamination bias is a type of error, usually in the positive direction, caused by the unwanted or unintended addition of a contaminant that was not present in the environmental matrix being sampled or that was present but below the LT-MDL. Potential bias to environmental sample results can be inferred from the results from the corresponding field blanks, provided that the field blanks were collected using the same sample handling processes as were used in collecting and analyzing the environmental samples, and provided that no additional biases resulted from contamination of the blank water itself.

Trace-element field-blank data were evaluated statistically to characterize the frequency and magnitude of extrinsic contamination bias, if any, for each constituent. For constituents that were found to have bias, results were compared with third-party laboratory blank data collected for quality-assurance purposes over the same period by the BQS Blind Blank Project, conducted through the USGS Office of Water Quality (results are identified by USGS test ID at http://bqs.usgs.gov/ $b b p /)$, to determine whether the bias was more likely due to field or to laboratory processes. Certificates of analysis for the UBW/IBW used for the field blanks, as well as results from source-solution blanks, also were used to determine whether any of the bias could be attributed to the blank water itself.
Three tools were used to evaluate the trace-element fieldblank data: (1) time-series plots, (2) detection frequencies, and (3) $90^{\text {th }}$ percentile concentrations calculated using the binomial probability distribution for greater than 90 percent confidence. These tools are described briefly.

Time-series plots were prepared for each constituent by plotting the trace-element results with concentration in micrograms per liter $(\mu \mathrm{g} / \mathrm{L})$ on the $\mathrm{y}$-axis, and sample date/ time on the x-axis. Nondetections were plotted at their respective LT-MDL concentrations, but are identified by a color different from that of the detections. For some constituents with observable contamination bias, additional plots were prepared to compare the field-blank data with the corresponding groundwater sample data. Time-series plots facilitate visual identification of patterns, trends, or clusters that could indicate a temporal component in the data, which might correspond to changes in the conditions under which the field blanks or groundwater samples were collected.

Detection frequencies were calculated for each trace element by dividing the number of detections in the field blanks by the total number of field blanks. The higher the detection frequency for the field blanks, the higher the likelihood of contamination bias, including bias that could have affected the groundwater samples.

$\mathbf{9 0}^{\text {th }}$ percentile concentrations were calculated for each trace element using the binomial probability distribution from the method reported by Hahn and Meeker (1991) as a way of determining an upper threshold for the contamination bias. This nonparametric approach was used to determine the $90^{\text {th }}$ percentile of the ranked field-blank data, with 90 percent or greater confidence. Calculations were made using the BINOMDIST function in Excel 2007 (Microsoft Corporation, Redmond, WA), which takes the form

$$
\begin{gathered}
C L=\text { BINOMDIST (number_s, trials, } \\
\text { probability_s, cumulative }),
\end{gathered}
$$

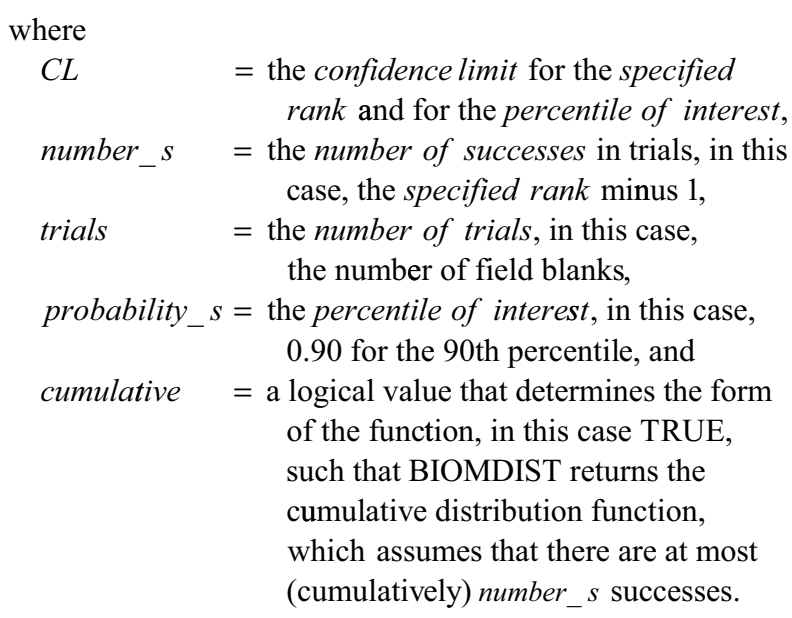


Table 1. Trace elements collected for the Groundwater Ambient Monitoring and Assessment (GAMA) program, comparative thresholds, and reporting information for the U.S. Geological Survey National Water Quality Laboratory, May 2004 through January 2008.

[The U.S. Geological Survey (USGS) test identification number, consisting of the parameter code and method code, is used to uniquely identify a specific constituent and its analytical method. Thresholds types and values as of December 1, 2007. Threshold type: MCL-CA, California Department of Health Services maximum contaminant level; MCL-US, U.S. Environmental Protection Agency maximum contaminant level; NL-CA, California Department of Health Services notification level; AL-US, U.S. Environmental Protection Agency action level; SMCL-CA, California Department of Health Services secondary maximum contaminant level; HAL-US, U.S. Environmental Protection Agency lifetime health advisory level. Other abbreviations: CAS, Chemical Abstract Service; LRL, laboratory reporting levels used by the USGS National Water Quality Laboratory during the study period; na, not applicable; $\mu \mathrm{g} / \mathrm{L}$, micrograms per liter]

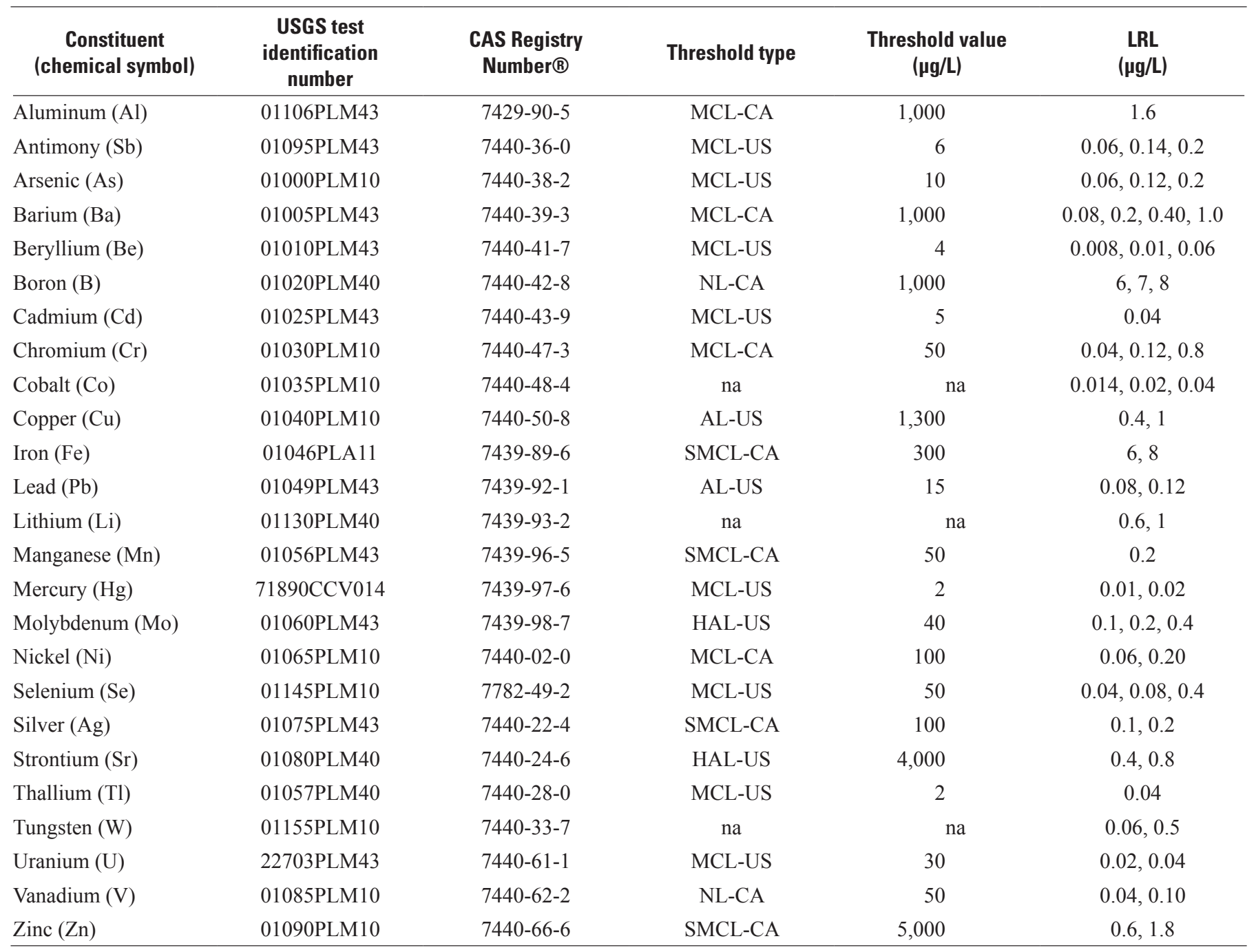

Calculations were made for each ranked concentration to determine which value corresponded to the lowest rank that represented an upper limit of the $90^{\text {th }}$ percentile with at least 90 percent confidence. In practice, the confidence limits obtained using this approach for the trace-element field blanks ranged from 93.6 to 95.8 percent. The concentration corresponding to the selected rank was then designated as the "BD-90/90" concentration or criterion (table 2). There is at least a 90-percent confidence that the contamination in at least 90 percent of all samples is less than the BD-90/90 concentration. 


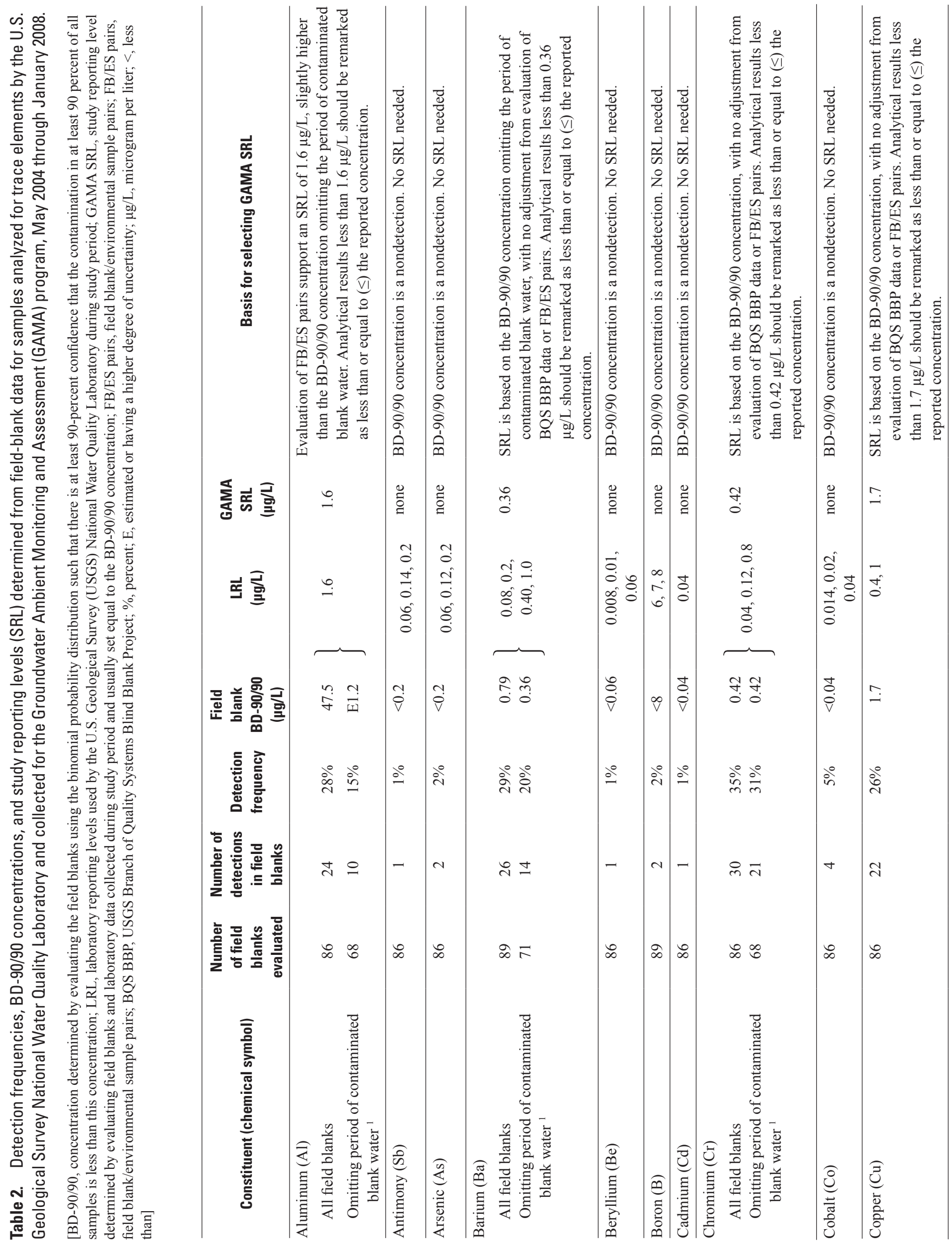




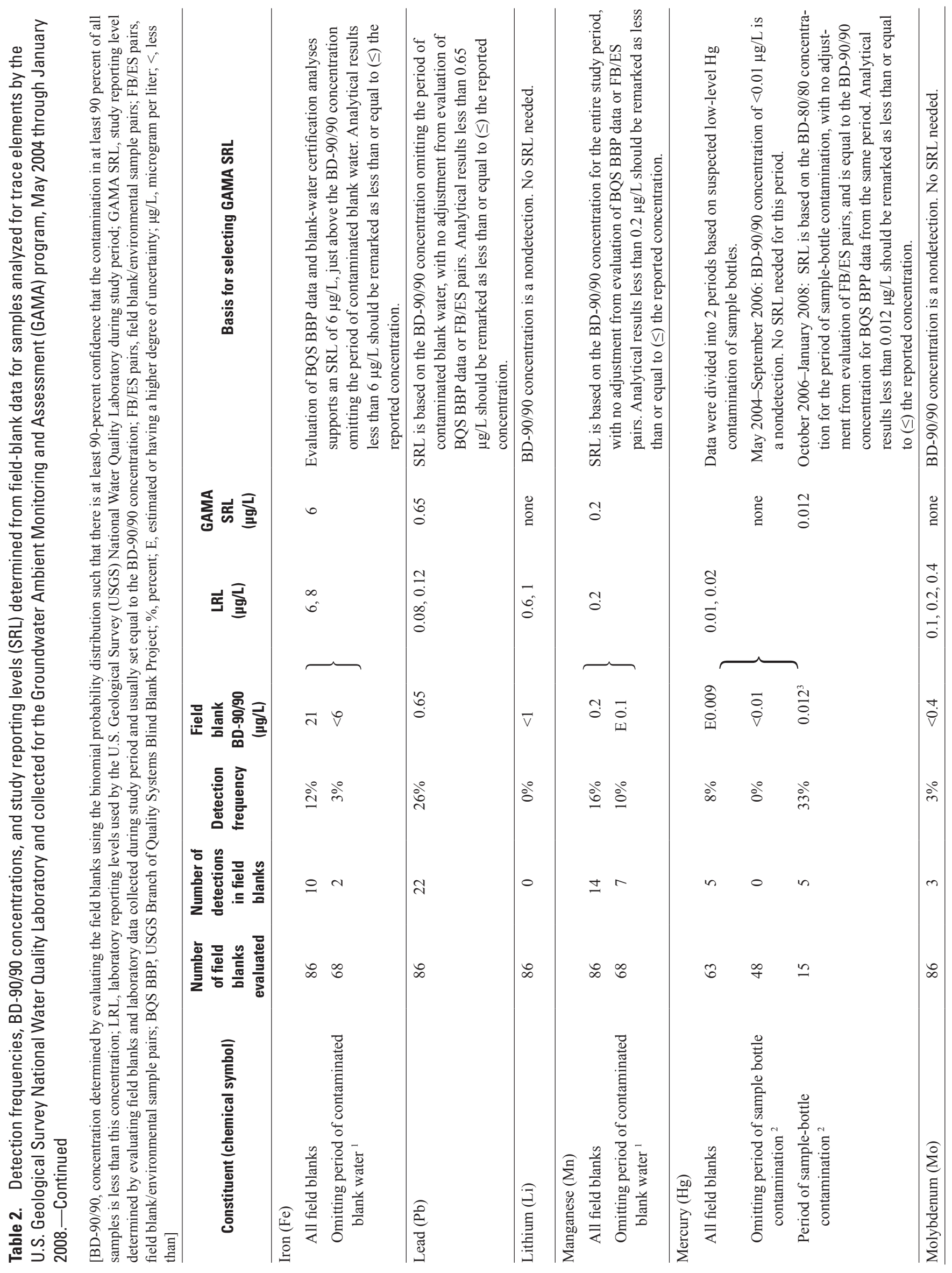




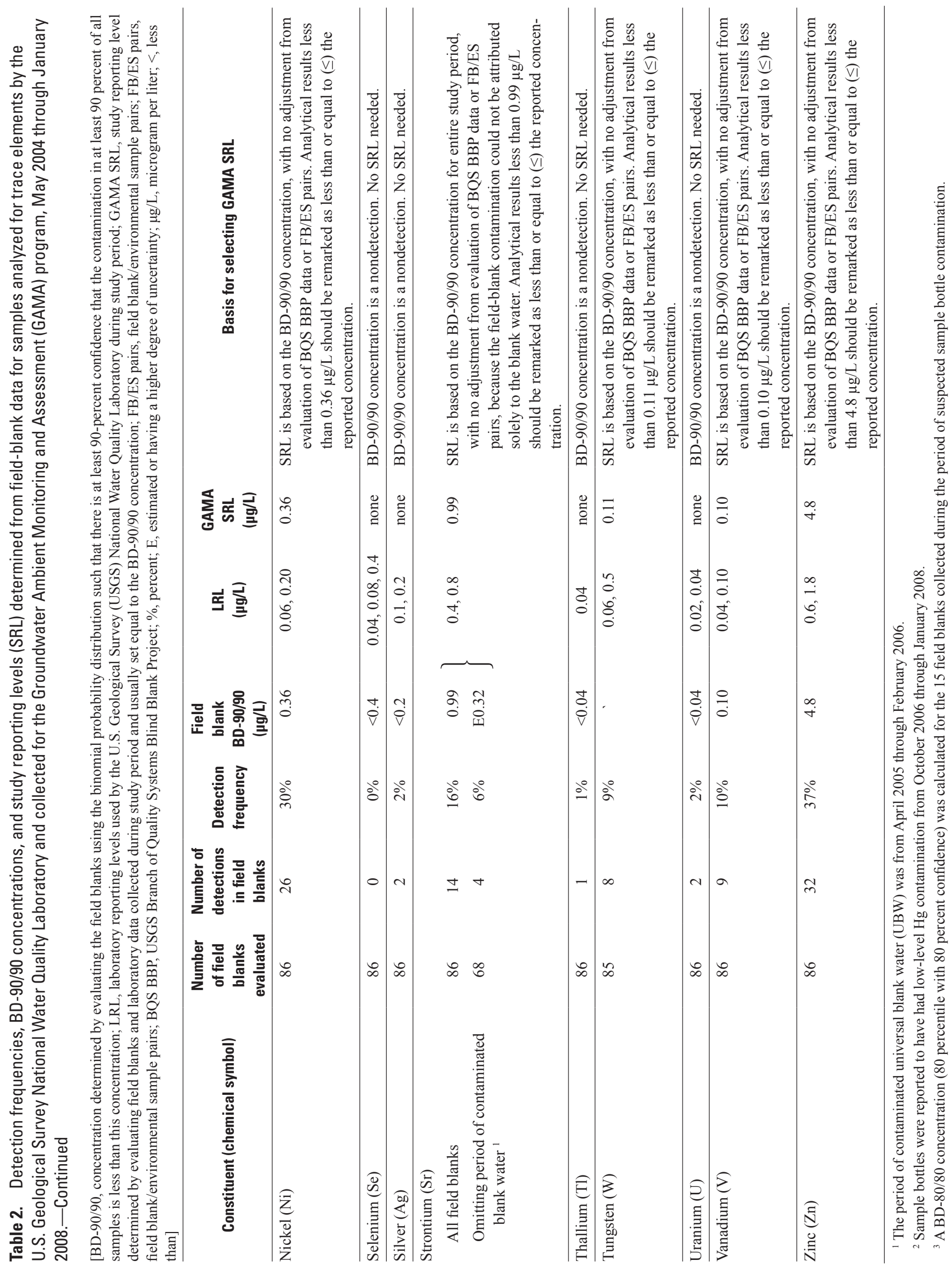


For trace elements that had BD-90/90 concentrations that were nondetections, contamination bias was not present, infrequent, or insignificant; therefore, no additional actions were taken for these constituents. For trace elements that had BD-90/90 concentrations above any of the LT-MDLs used during the study period, the chance that a concentration below its respective $\mathrm{BD}-90 / 90$ concentration was a false positive was greater than 10 percent, on the basis of the extrinsic contamination indentified in the field blanks. For these trace elements, if the contamination could not be attributed chiefly to the blank water used, a study reporting level (SRL) was set equal to the BD-90/90 concentration. Concentrations below an SRL are considered to have an unacceptably high likelihood of positive bias, and therefore, should be reported as less than or equal to ("S") the reported value (for example, for a trace element with an SRL of $1.6 \mu \mathrm{g} / \mathrm{L}$, a result of $1.4 \mu \mathrm{g} / \mathrm{L}$ should be reported as $\leq 1.4 \mu \mathrm{g} / \mathrm{L}$ ). By reporting detections below the SRL as " $\leq$ " the reported value, data users will know the magnitude of each detected concentration, but will know that the true concentration could be less than or equal to the "detected" concentration.

Figure 2 illustrates the data reporting notation showing the three possible relations between the BD-90/90 concentration and the LRL, the LT-MDL, and possible SRLs. In case 1, the BD-90/90 concentration is less than the LT-MDL and is reported as $<\mathrm{LRL}$ (a nondetection); therefore, no SRL was defined and no changes to the data reporting notation were required. In case 2, the BD-90/90 is between the LRL and the LT-MDL, and an SRL was defined to be equal to the BD-90/90 concentration. For case 2, values below the LRL but above the SRL are remarked with an E code, and values between the SRL and the LT-MDL are remarked as less than or equal $(\leq)$ to the reported value. In case 3 , the BD-90/90 concentration is greater than the LRL, and an SRL was defined to be equal to the BD-90/90 concentration. For case 3, values below the SRL but above the LT-MDL were remarked as less than or equal to $(\leq)$ the reported value.

Finally, to ensure that applying SRLs would not interfere with comparing groundwater sample results with any $\mathrm{CDPH}$ or USEPA regulatory thresholds established for drinking water for human health or aesthetic purposes (California Department of Health Services, 2007; U.S. Environmental Protection Agency, 2006), the SRLs were reviewed against these thresholds. Comparative thresholds and threshold types are listed in table 1 and below:

- MCL-Maximum Contaminant Level. A legally enforceable standard for public-water systems that is designed to protect public health by limiting the levels of contaminants in drinking water. MCLs established by the USEPA are the minimum standards with which states are required to comply; individual states may set more stringent standards. CDPH has established MCLs for several constituents that are not regulated by the USEPA and has lowered the thresholds for some constituents with USEPA MCLs. In this document, an MCL set by the USEPA and adopted by CDPH is labeled "MCL-US" and the one set by CDPH that is more stringent than the MCL-US is labeled "MCL-CA."

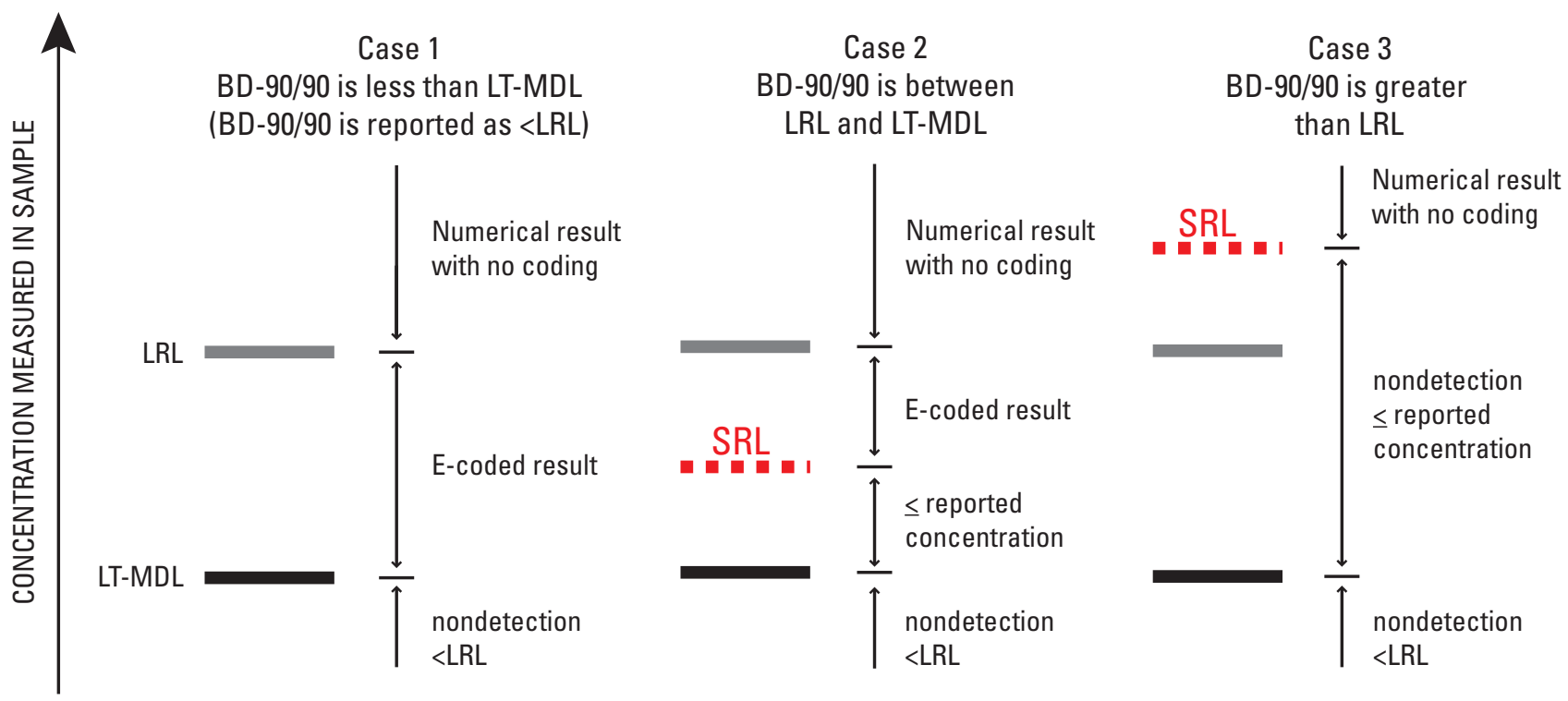

Figure 2. Three possible relations between the BD-90/90 concentration and the LRL, the LT-MDL, and the SRL, and the resulting reporting notation for environmental samples. BD-90/90, 90th percentile concentration determined using binomial distribution with a confidence level that is 90 percent or greater; LT-MDL, long-term method detection level; LRL, laboratory reporting level; SRL, study reporting level; E, estimated or having a higher degree of uncertainty; $\leq$, less than or equal to; $<$, less than. 
- AL-Action Level. A legally enforceable standard that applies to public-water systems that is designed to protect public health by limiting the levels of copper and lead in drinking water. Concentrations of copper or lead above this standard trigger requirements for mandatory water treatment to reduce the corrosiveness of water to copper and lead pipes. Action levels established by the USEPA and CDPH were the same during this study and are labeled "AL-US" in this document.

- SMCL-Secondary Maximum Contaminant Level. A non-enforceable standard that applies to constituents that affect the aesthetic qualities of drinking water, such as taste, odor, and color, or technical qualities, such as scaling and staining. Both the USEPA and CDPH define SMCLs, but unlike MCLs, SMCLs established by CDPH are not required to be at least as stringent as those established by the USEPA. SMCLs established by CDPH (labeled "SMCL-CA") are used for all constituents that have SMCL-CA values.

- NL-Notification Level. A health-based notification level established by CDPH for some of the constituents in drinking water that lack MCLs, and labeled "NL-CA" in this document. If a constituent is detected above its NL-CA, California law requires timely notification of local governing bodies and recommends consumer notification.

- HAL - Lifetime Health Advisory Level. The maximum concentration of a constituent at which its presence in drinking water is not expected to cause any adverse carcinogenic effects for a lifetime of exposure. HALs are established by the USEPA (labeled "HALUS") and are calculated by assuming consumption of $2 \mathrm{~L}$ (2.1 quarts) of water per day over a 70-year lifetime by a 70-kilogram (154-pound) adult and that 20 percent of a person's exposure comes from drinking water.

For trace elements having multiple types of thresholds, the threshold used for comparisons in this document might not always be the lowest one. Legally enforceable thresholds (MCLs and ALs) were given preference over non-enforceable thresholds (SMCLs). Concentrations of constituents that lack an MCL, AL, or SMCL were compared to the NL-CA. For constituents that lack an MCL, AL, SMCL, or NL-CA, concentrations were compared with the HAL-US. Not all constituents analyzed for this study have established thresholds. The thresholds in table 1 are provided for comparison purposes only and are not meant to be applied in a regulatory sense to the untreated groundwater resources sampled for this project. Untreated groundwater is usually subjected to filtration, disinfection, exposure to the atmosphere, and additional treatment processes prior to delivery as drinking water to consumers.

\section{Trace-Element Contamination Bias}

The potential for extrinsic contamination bias in the groundwater samples was evaluated for each trace element. Results of this evaluation were categorized into two groups: (1) trace elements detected in less than 5 percent of the field blanks (these had BD-90/90 concentrations that were below the LT-MDL) and (2) trace elements detected in more than 5 percent of field blanks (these had BD-90/90 concentrations that were above the LT-MDL).

Eighty-six field blanks were analyzed for all of the trace elements except barium and boron (which had 89 field blanks), mercury (which had 63 field blanks), and tungsten (which had 85 field blanks). For 86 ranked values, the $82^{\text {nd }}$ value statistically defines the BD-90/90 concentration. Thus, the detection frequency in a population of 86 field blanks must be below 5.8 percent for the BD-90/90 concentration to be referred to as a nondetection. For this evaluation, all trace elements whose BD-90/90 concentrations were below the LT-MDL also had detection frequencies below 5 percent; therefore, a detection frequency of 5 percent was used as a threshold for identifying trace elements requiring additional scrutiny and possible establishment of an SRL.

Detection frequencies and BD-90/90 concentrations for the field blanks are tabulated on table 2 .

\section{Trace Elements Detected in Fewer Than 5 Percent of Field Blanks (Sb, As, Be, B, Cd, Co, Li, Mo, Se, Ag, TI, and U)}

Of the trace elements analyzed for samples collected from May 2004 through January 2008 for the GAMA Priority Basins Project, only Li and Se were not detected in the field blanks. Ten other trace elements ( $\mathrm{Sb}, \mathrm{As}, \mathrm{Be}, \mathrm{B}, \mathrm{Cd}, \mathrm{Co}, \mathrm{Mo}$, $\mathrm{Ag}, \mathrm{Tl}$, and $\mathrm{U}$ ) were detected in fewer than 5 percent of the field blanks and thus have BD-90/90 concentrations that are considered to be nondetections. These 12 trace elements did not have any systematic laboratory contamination supported by the BQS Blind Blank Project data; BD-90/90 concentrations calculated from the $\mathrm{BQS}$ data for these constituents were all well below their respective LT-MDLs (table 3). Therefore, it was not necessary to establish an SRL for these 12 trace elements on the basis of either the field-blank data or the thirdparty laboratory blank data. Concentrations of each of these 12 trace elements in the field blanks, and the BD-90/90 concentrations for each trace element are plotted in figures $3 A-L$. 
Table 3. Assessment of blind blanks submitted by the U.S. Geological Survey (USGS) Branch of Quality Systems (BOS) Blind Blank Project and analyzed for trace elements by the USGS National Water Quality Laboratory, including laboratory reporting levels and BD-90/90 concentrations, May 2004 through January 2008.

[LRL, laboratory reporting levels used by the USGS National Water Quality Laboratory from May 2004 through January 2008; long-term method detection limits (LT-MDL) are equivalent to 1/2 the respective LRLs; $\mu \mathrm{g} / \mathrm{L}$, microgram per liter; ; >, greater than; $\leq$, less than or equal to. Data used for the BQS Blind Blank Project BD-90/90 calculations are available from http://bqs.usgs.gov/bbp/BBPICPMS_Fil.html]

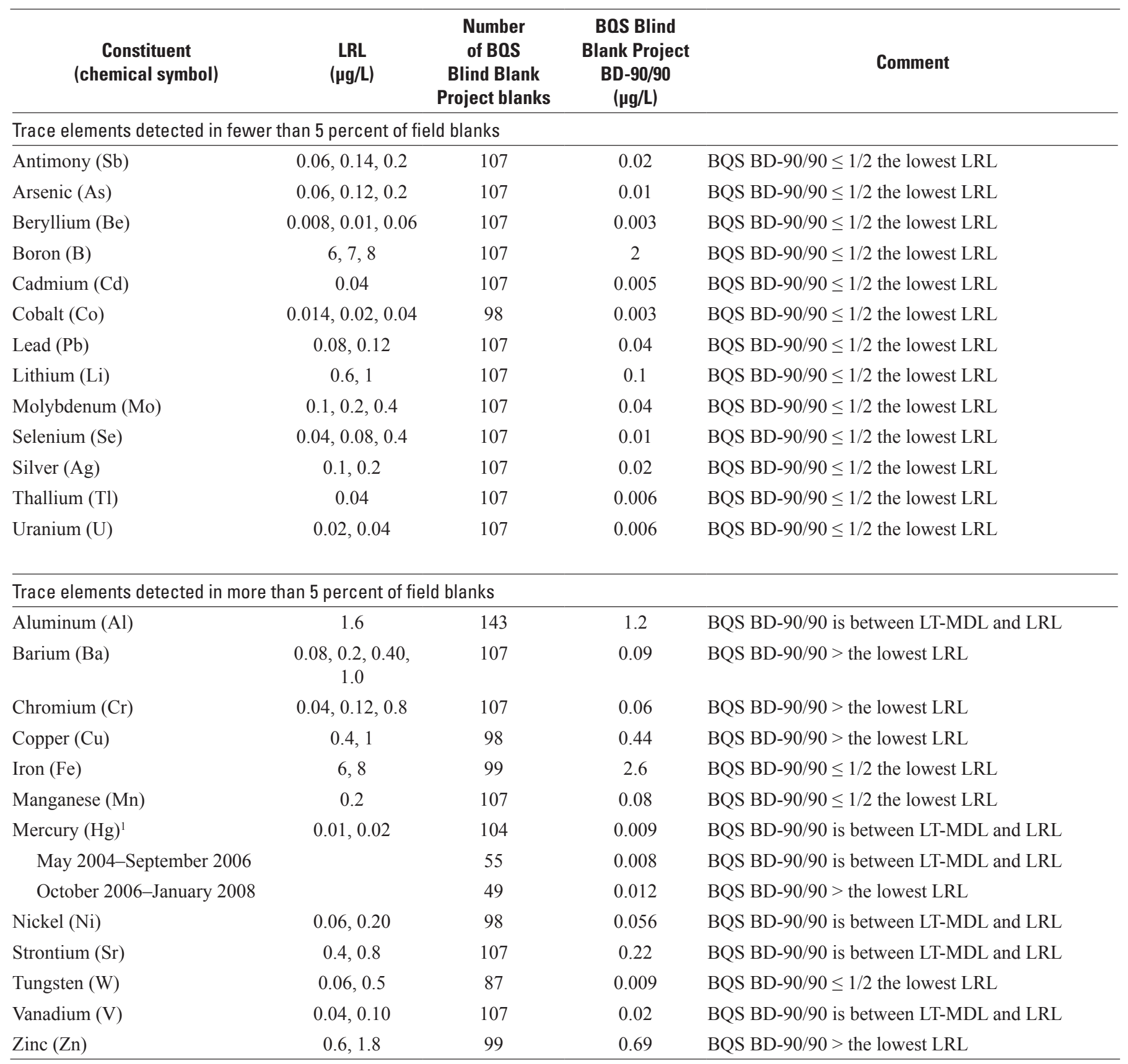

\footnotetext{
${ }^{1}$ Sample bottles were reported to have had low-level Hg contamination from October 2006 through January 2008, so data were divided by time period.
} 

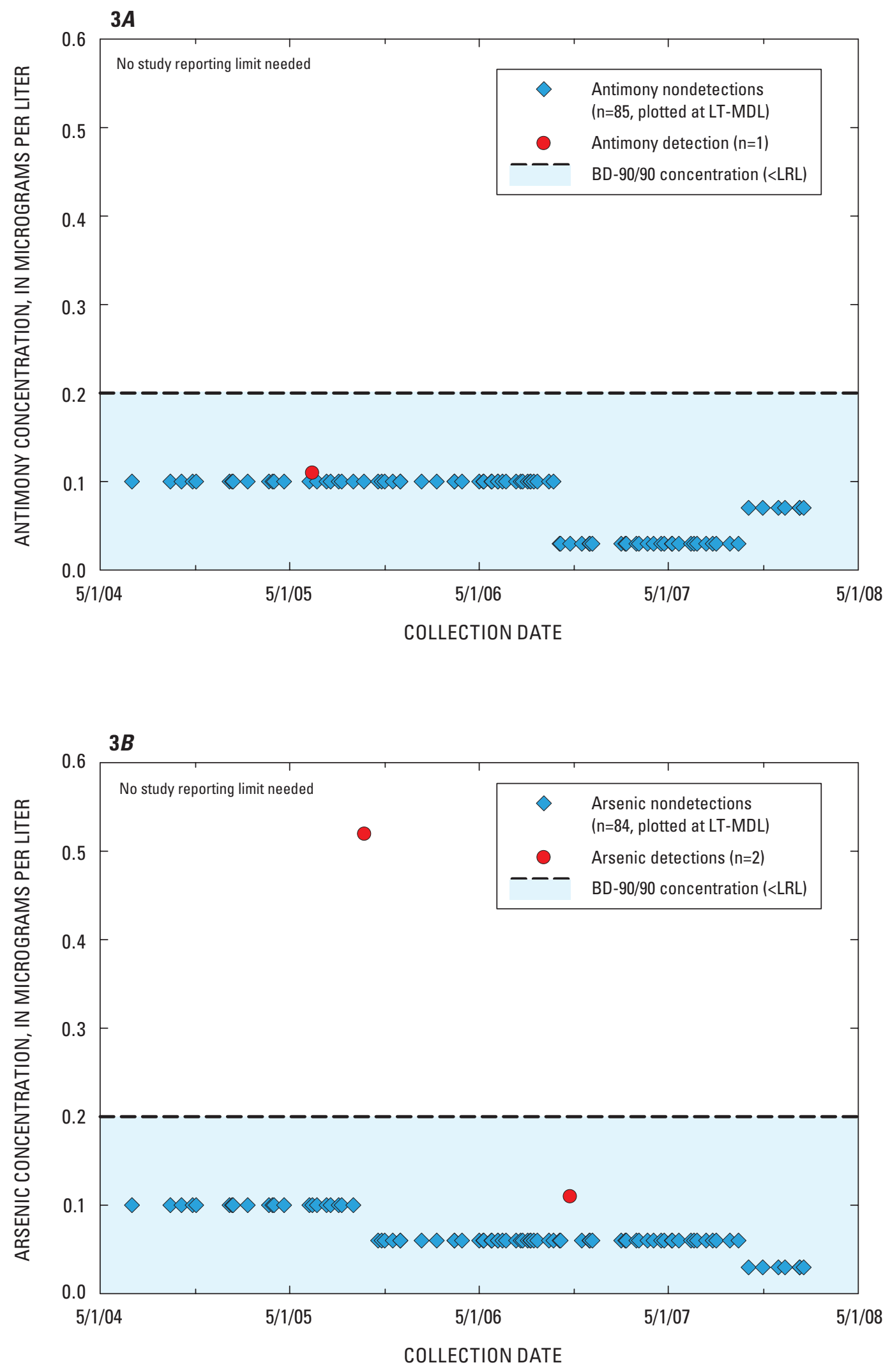

Figure 3. Trace-element concentrations and BD-90/90 concentrations for constituents detected in fewer than 5 percent of the field blanks collected from May 2004 through January 2008 for $A$. antimony (Sb), B. arsenic (As). BD-90/90, 90th percentile concentration determined using binomial distribution with a confidence level that is 90 percent or greater. LT-MDL, long-term method detection level; LRL, laboratory reporting level. 

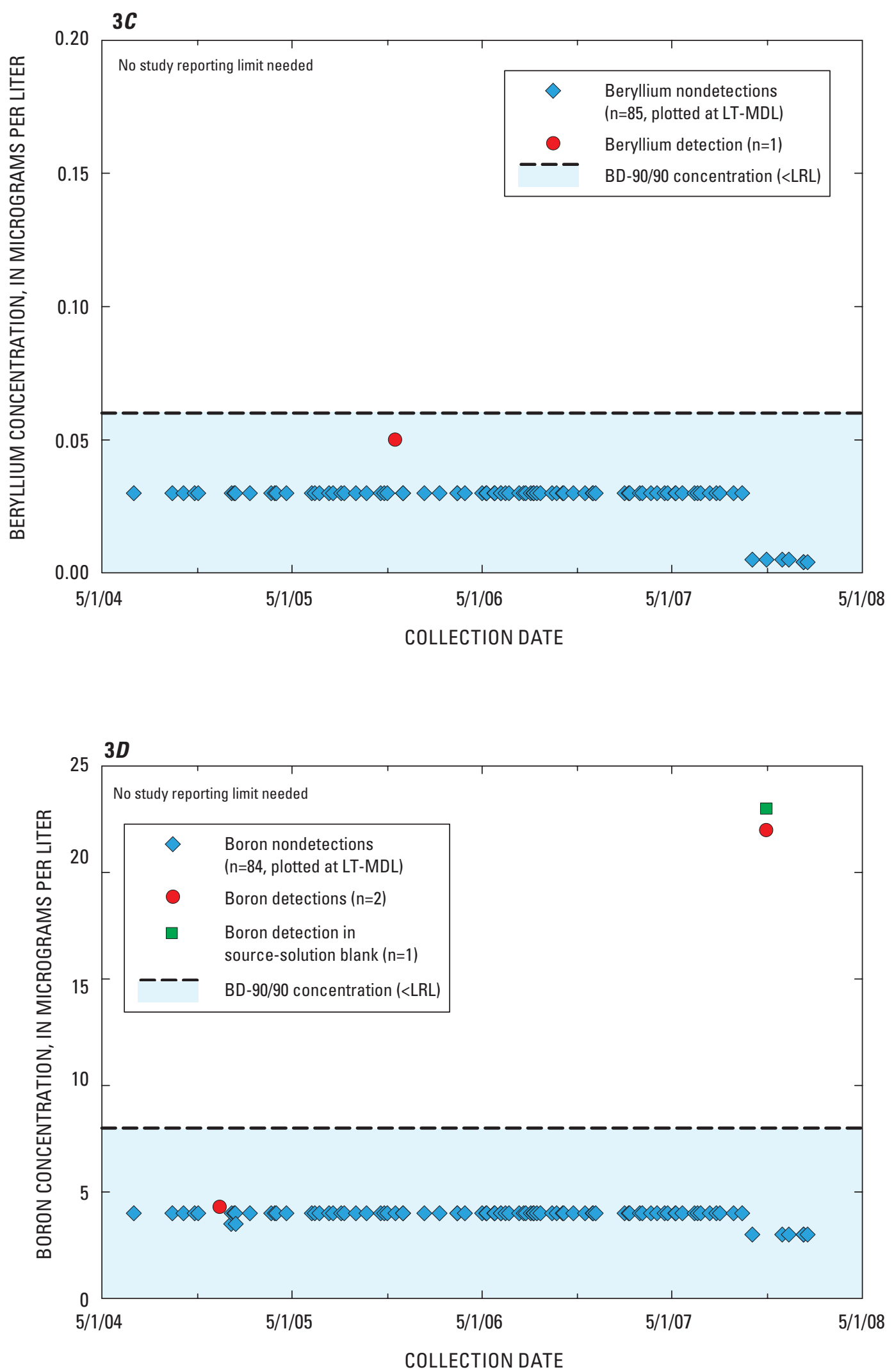

Figure 3.-Continued. Trace-element concentrations and BD-90/90 concentrations for constituents detected in fewer than 5 percent of the field blanks collected from May 2004 through January 2008 for $C$. beryllium (Be), and D. boron (B). BD-90/90, 90th percentile concentration determined using binomial distribution with a confidence level that is 90 percent or greater. LT-MDL, long-term method detection level; LRL, laboratory reporting level. 

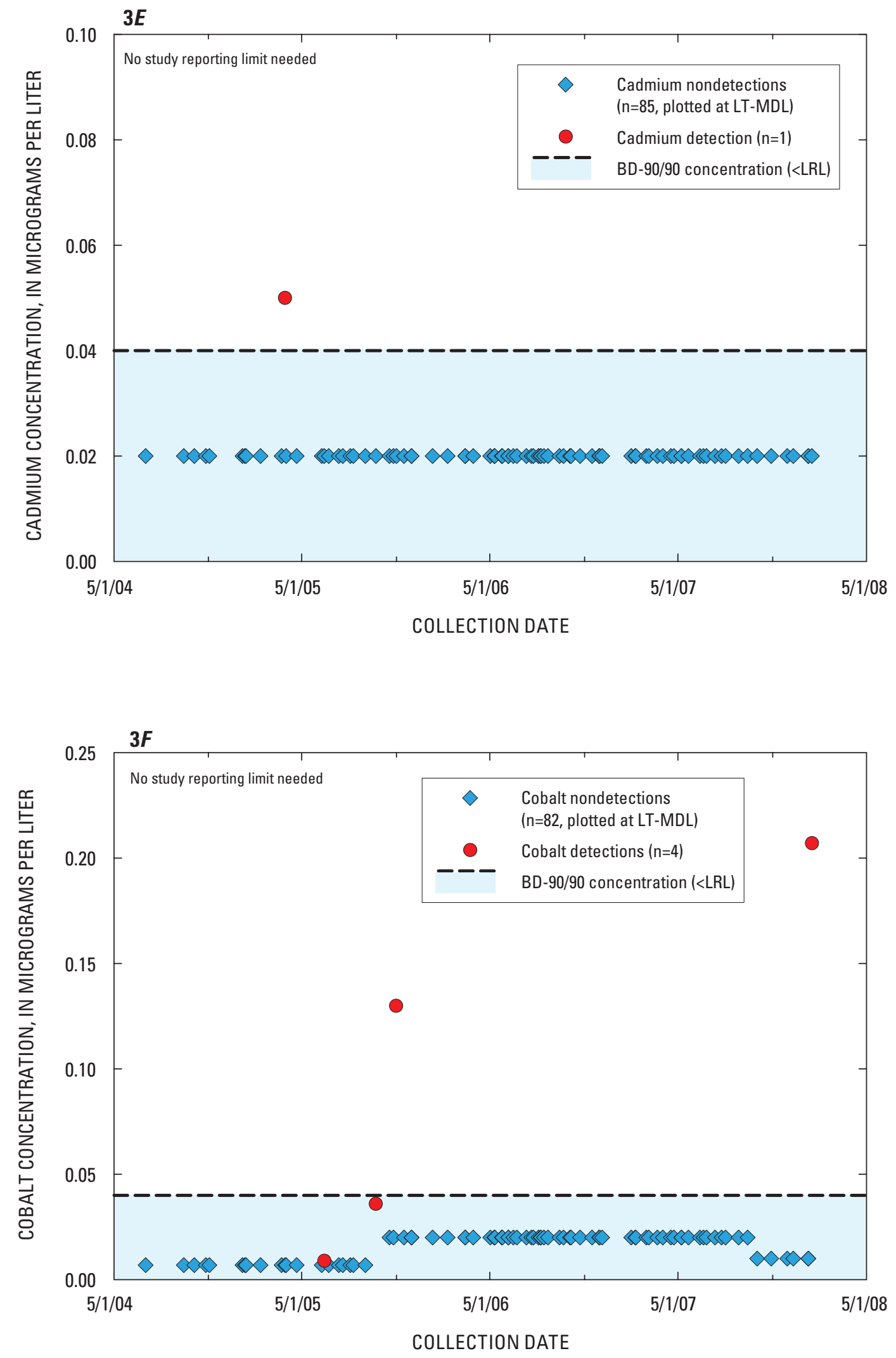

Figure 3.-Continued. Trace-element concentrations and BD-90/90 concentrations for constituents detected in fewer than 5 percent of the field blanks collected from May 2004 through January 2008 for E. cadmium (Cd) and F. cobalt (Co). BD-90/90, 90th percentile concentration determined using binomial distribution with a confidence level that is 90 percent or greater. LT-MDL, long-term method detection level; LRL, laboratory reporting level. 

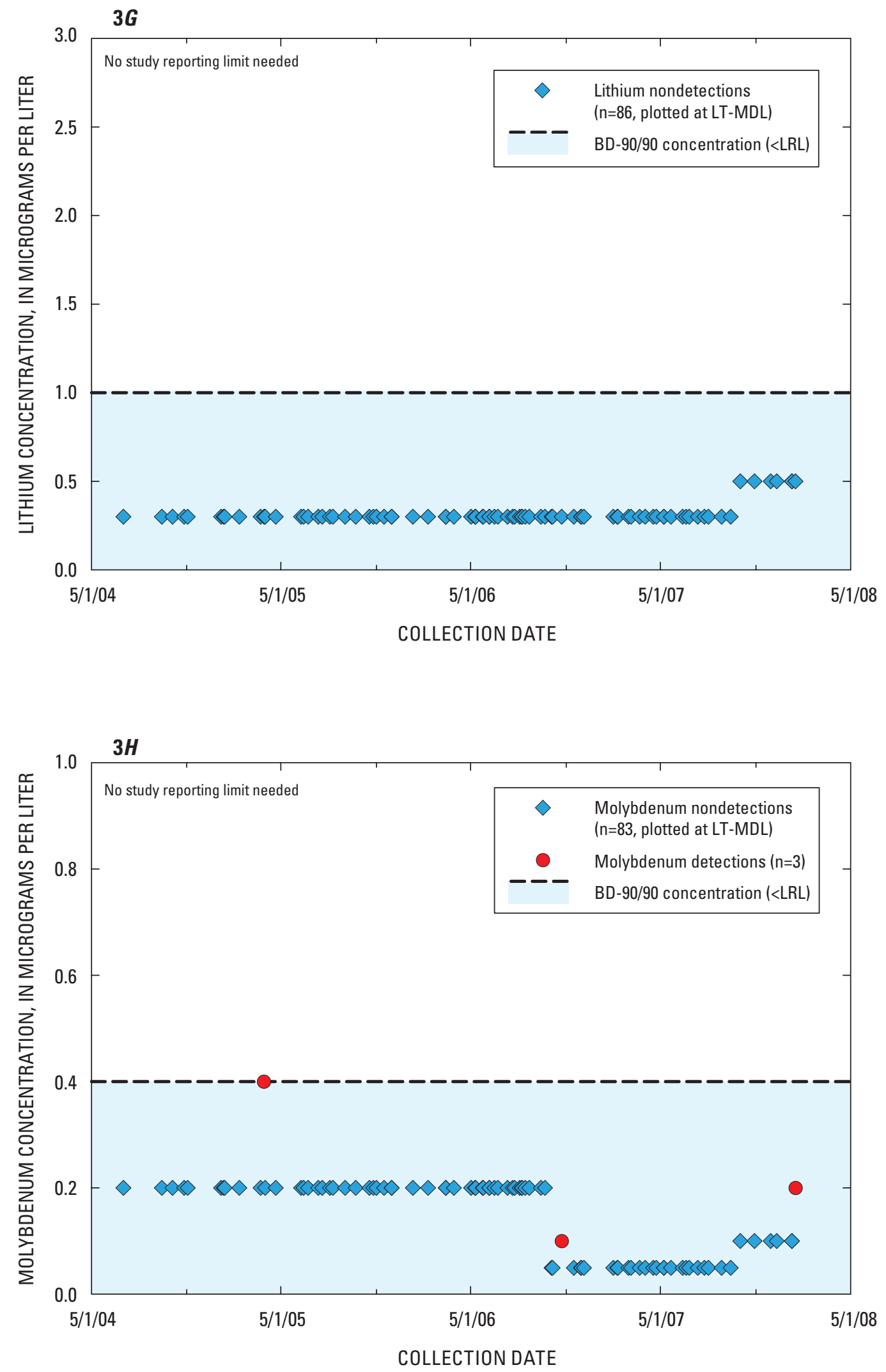

Figure 3.-Continued. Trace-element concentrations and BD-90/90 concentrations for constituents detected in fewer than 5 percent of the field blanks collected from May 2004 through January 2008 for $G$. lithium (Li) and $H$. molybdenum (Mo). BD-90/90, 90th percentile concentration determined using binomial distribution with a confidence level that is 90 percent or greater. LT-MDL, long-term method detection level; LRL, laboratory reporting level. 

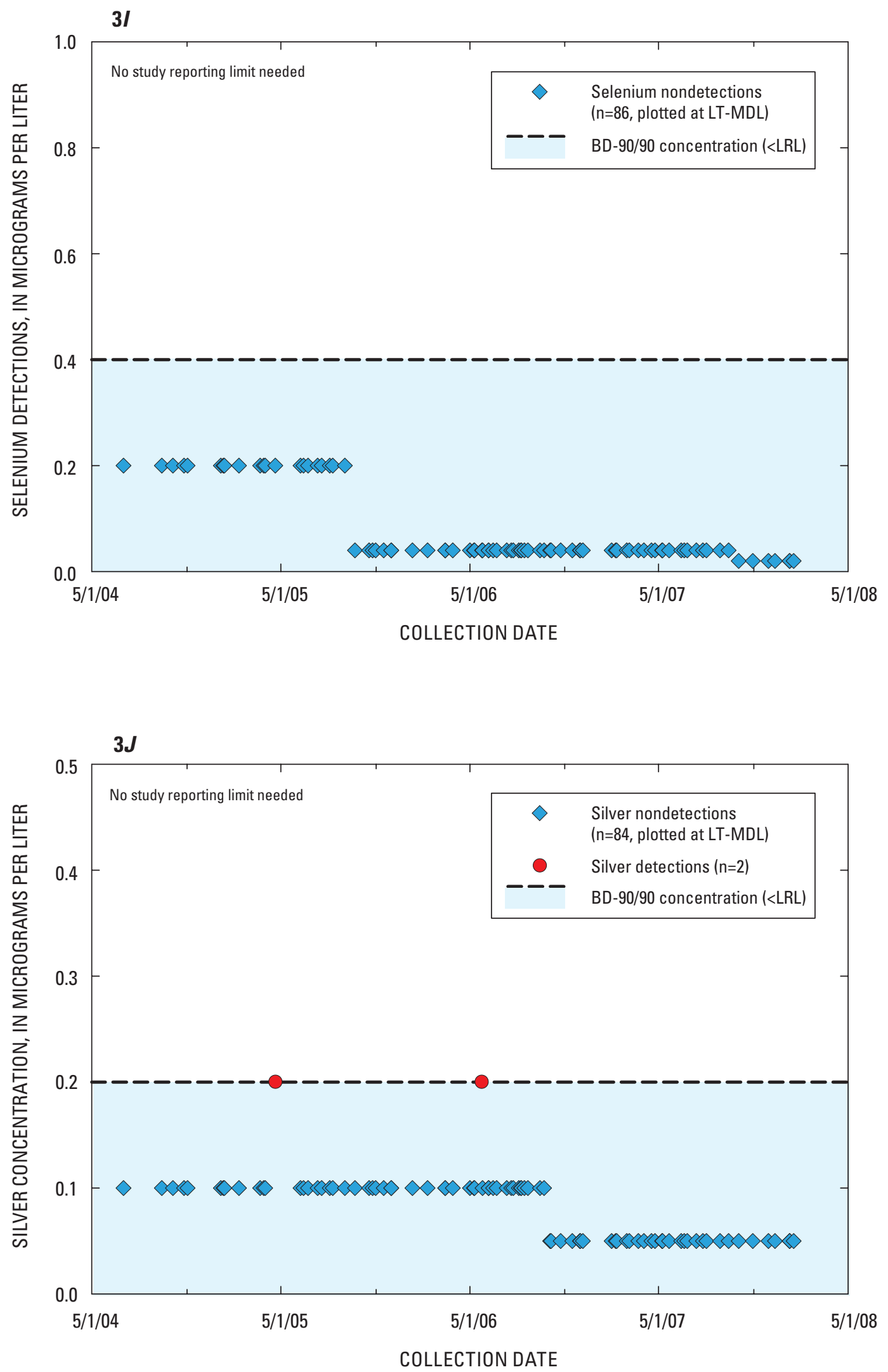

Figure 3.-Continued. Trace-element concentrations and BD-90/90 concentrations for constituents detected in fewer than 5 percent of the field blanks collected from May 2004 through January 2008 for I. selenium (Se) and J. silver (Ag). BD-90/90, 90th percentile concentration determined using binomial distribution with a confidence level that is 90 percent or greater. LT-MDL, long-term method detection level; LRL, laboratory reporting level. 

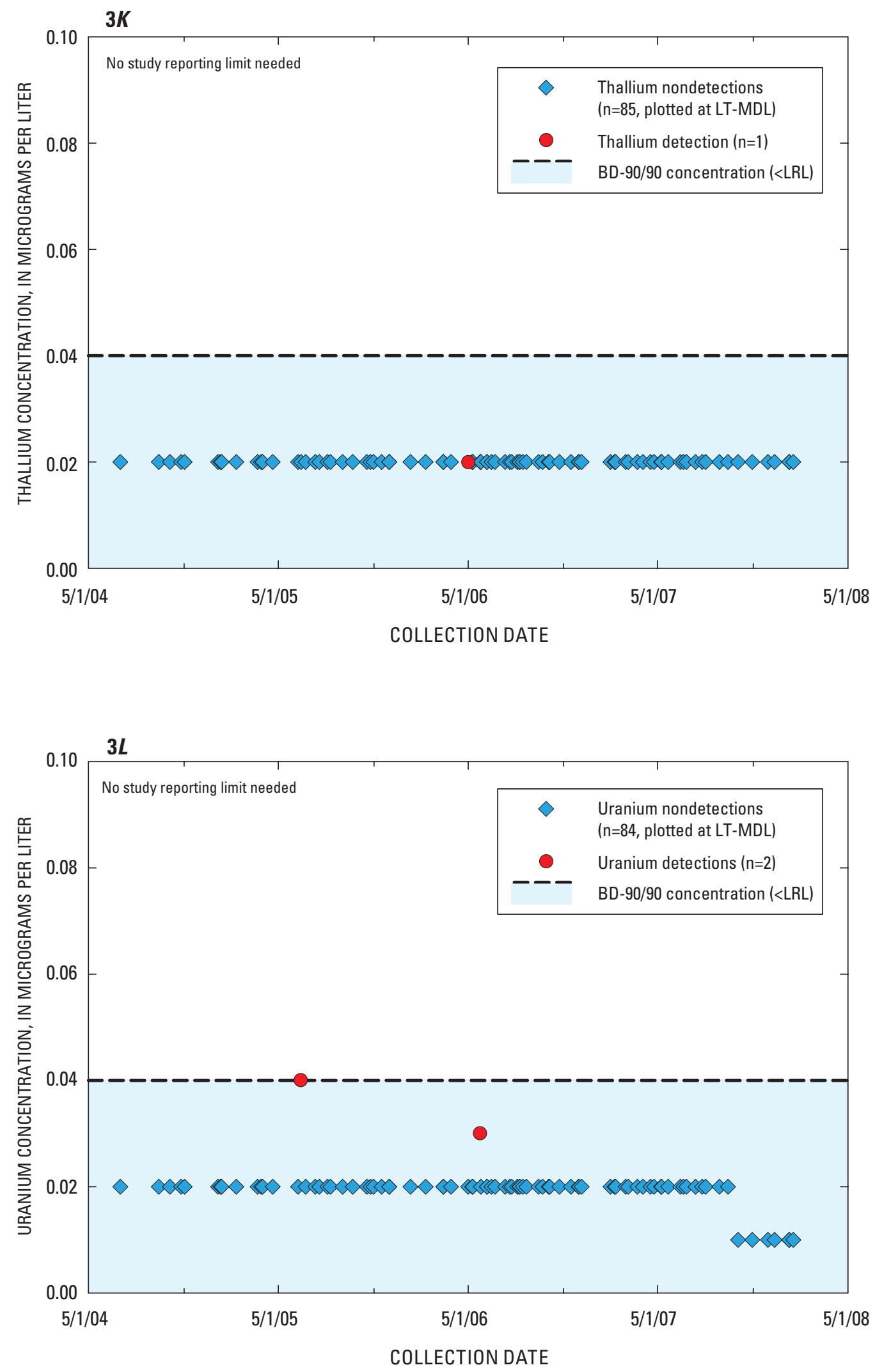

Figure 3.-Continued. Trace-element concentrations and BD-90/90 concentrations for constituents detected in fewer than 5 percent of the field blanks collected from May 2004 through January 2008 for $K$. thallium (TI) and L. uranium (U). BD-90/90, 90th percentile concentration determined using binomial distribution with a confidence level that is 90 percent or greater. LT-MDL, long-term method detection level; LRL, laboratory reporting level. 


\section{Antimony (Sb)}

Only 1 of 86 field blanks ( 1 percent) collected for antimony had a detection (fig. 3A, table 2). This detected concentration, $\mathrm{E} 0.11 \mu \mathrm{g} / \mathrm{L}$, was below the highest LRL used by the NWQL during the study period $(0.2 \mu \mathrm{g} / \mathrm{L})$. The BD-90/90 concentration for antimony in field blanks was $<0.2 \mu \mathrm{g} / \mathrm{L}$; therefore, it was unnecessary to establish an SRL for antimony on the basis of the field-blank data. Antimony was not detected in any of the 15 source-solution blanks, and the BQS Blind Blank Project data did not indicate any systematic laboratory contamination (the BQS BD-90/90 concentration was below all LRLs and LT-MDLs) (table 3).

\section{Arsenic (As)}

Only 2 of 86 field blanks (2 percent) collected for arsenic had detections (fig. 3B, table 2). One detected concentration $(\mathrm{E} 0.11 \mu \mathrm{g} / \mathrm{L})$ was below the highest LRL used by the NWQL during the study period $(0.2 \mu \mathrm{g} / \mathrm{L})$, and the other detected concentration $(0.52 \mu \mathrm{g} / \mathrm{L})$ was above the highest LRL. The BD-90/90 concentration for arsenic was $<0.2 \mu \mathrm{g} / \mathrm{L}$; therefore, it was unnecessary to establish an SRL for arsenic on the basis of the field-blank data. Arsenic was not detected in any of the 15 source-solution blanks, and the BQS Blind Blank Project data did not indicate any systematic laboratory contamination (table 3).

\section{Beryllium (Be)}

Only 1 of 86 field blanks collected for beryllium had a detection (fig. 3C, table 2). This detected concentration of $\mathrm{E} 0.05 \mu \mathrm{g} / \mathrm{L}$ was below the highest LRL used by the NWQL during the study period $(0.06 \mu \mathrm{g} / \mathrm{L})$. The BD-90/90 concentration for beryllium was $<0.06 \mu \mathrm{g} / \mathrm{L}$; therefore, it was unnecessary to establish an SRL for beryllium on the basis of the field-blank data. Beryllium was not detected in any of 15 source-solution blanks, and the BQS Blind Blank Project data did not indicate any systematic laboratory contamination (table 3).

\section{Boron (B)}

Only 2 of 89 field blanks ( 2 percent) collected for boron had detections (fig. 3D, table 2). One of these detected concentrations $(\mathrm{E} 4.3 \mu \mathrm{g} / \mathrm{L})$ was below the highest LRL used by the NWQL during the study period $(8 \mu \mathrm{g} / \mathrm{L})$. The other concentration was $22 \mu \mathrm{g} / \mathrm{L}$ in a field blank collected on October 29 , 2007. A source-solution blank collected immediately before this field blank had a concentration of $23 \mu \mathrm{g} / \mathrm{L}$. Four bottles of the IBW (NWIS-I Lot Number 80703) analyzed by the
NWQL had boron concentrations ranging from 21 to $22 \mu \mathrm{g} / \mathrm{L}$ (appendix table A1); therefore, the IBW was identified as the source of the boron contamination in the field blank collected on $10 / 29 / 2007$. This source of contamination was unique to a subset of the blanks and did not affect any of the groundwater samples. The BQS Blind Blank Project data did not indicate any systematic laboratory contamination (table 3 ), and boron was not detected in the other 14 source-solution blanks (of 15 collected). The BD-90/90 concentration for boron was $<8 \mu \mathrm{g} / \mathrm{L}$; therefore, it was unnecessary to establish an SRL for boron on the basis of the field-blank data.

\section{Cadmium (Cd)}

Only 1 of 86 field blanks (1 percent) collected for cadmium had a detection (fig. 3E, table 2). The detected concentration, $0.05 \mu \mathrm{g} / \mathrm{L}$, was very close to the $\mathrm{LRL}$ that was used throughout the study period, $0.04 \mu \mathrm{g} / \mathrm{L}$. The BD-90/90 concentration for cadmium was $<0.04 \mu \mathrm{g} / \mathrm{L}$; therefore, it was unnecessary to establish an SRL for cadmium on the basis of the field-blank data. Cadmium also was not detected in any of 15 source-solution blanks, and the BQS Blind Blank Project data did not indicate any systematic laboratory contamination for cadmium (table 3).

\section{Cobalt (Co)}

Four of 86 field blanks ( 5 percent) collected for cobalt had detections (fig. 3F, table 2). These detection concentrations were $\mathrm{E} 0.009,0.04,0.13$, and $0.21 \mu \mathrm{g} / \mathrm{L}$. Only two of these detections were above the highest LRL used by the NWQL during the study period $(0.04 \mu \mathrm{g} / \mathrm{L})$. The BD-90/90 concentration for cobalt was $<0.04 \mu \mathrm{g} / \mathrm{L}$; therefore, it was unnecessary to determine an SRL for cobalt on the basis of the field-blank data. Cobalt also was not detected in any of 15 source-solution blanks and did not have any systematic laboratory contamination based on the BQS Blind Blank Project data (table 3).

\section{Lithium (Li)}

None of the 86 field blanks ( 0 percent) collected for lithium had detections (fig. 3G, table 2). The BD-90/90 concentration for lithium was $<1 \mu \mathrm{g} / \mathrm{L}$; therefore, it was unnecessary to determine an SRL for lithium on the basis of the field-blank data, and there was no need to consider the source-solution blanks or laboratory performance data. 


\section{Molybdenum (Mo)}

Three of the 86 field blanks ( 3 percent) collected for molybdenum had detections (fig. $3 \mathrm{H}$, table 2). These detected concentrations ranged from E0.1 to $0.4 \mu \mathrm{g} / \mathrm{L}$, which was at or below the highest LRL used by the NWQL during the study period $(0.4 \mu \mathrm{g} / \mathrm{L})$. The BD-90/90 concentration for molybdenum was $<0.4 \mu \mathrm{g} / \mathrm{L}$; therefore, it was unnecessary to establish an SRL for molybdenum on the basis of the field-blank data. Molybdenum was not detected in any of 15 source-solution blanks and did not have any systematic laboratory contamination based on the BQS Blind Blank Project data (table 3).

\section{Selenium (Se)}

None of the 86 field blanks ( 0 percent) collected for selenium had detections (fig. 3I, table 2). The BD-90/90 concentration for selenium was $<0.4 \mu \mathrm{g} / \mathrm{L}$; therefore, it was unnecessary to determine an SRL for selenium on the basis of the field-blank data, and there was no need to consider the source-solution blanks or laboratory performance data.

\section{Silver (Ag)}

Only 2 of the 86 field blanks ( 2 percent) collected for silver had detections (fig. 3J, table 2). Both of these detected concentrations were $\mathrm{E} 0.2 \mu \mathrm{g} / \mathrm{L}$, which was equal to the highest LRL used by the NWQL during the study period $(0.2 \mu \mathrm{g} / \mathrm{L})$. The BD-90/90 concentration for silver was $<0.2 \mu \mathrm{g} / \mathrm{L}$; therefore, it was unnecessary to establish an SRL for silver on the basis of the field-blank data. Silver was not detected in any of 15 source-solution blanks and did not have any systematic laboratory contamination based on the BQS Blind Blank Project data (table 3).

\section{Thallium (TI)}

Only 1 of 86 field blanks ( 1 percent) collected for thallium had a detection (fig. $3 K$, table 2 ). The detected concentration, E0.02 $\mu \mathrm{g} / \mathrm{L}$, was below the LRL, $0.04 \mu \mathrm{g} / \mathrm{L}$, that was used by the NWQL throughout the study period. The BD- $90 / 90$ concentration for thallium was $<0.04 \mu \mathrm{g} / \mathrm{L}$; therefore, it was unnecessary to establish an SRL for thallium on the basis of the field-blank data. Thallium was not detected in any of 15 source-solution blanks and did not have any systematic laboratory contamination based on the BQS Blind Blank Project data (table 3).

\section{Uranium (U)}

Only 2 of 86 field blanks ( 2 percent) collected for uranium had detections (fig. $3 L$, table 2). These two detected concentrations were E0.03 and $0.04 \mu \mathrm{g} / \mathrm{L}$, which were at or below the highest LRL used during the study period $(0.04 \mu \mathrm{g} / \mathrm{L})$. The BD-90/90 concentration for uranium was $<0.04 \mu \mathrm{g} / \mathrm{L}$; therefore, it was unnecessary to establish an SRL for uranium on the basis of the field-blank data. Uranium was not detected in any of 15 source-solution blanks and did not have any systematic laboratory contamination based on the BQS Blind Blank Project data (table 3).

\section{Trace Elements Detected in More than 5 Percent of Field Blanks ( $\mathrm{Al}, \mathrm{Ba}, \mathrm{Cr}, \mathrm{Cu}, \mathrm{Fe}, \mathrm{Pb}, \mathrm{Mn}, \mathrm{Hg}, \mathrm{Ni}$, $\mathrm{Sr}, \mathrm{W}, \mathrm{V}$, and $\mathrm{Zn}$ )}

Thirteen of the trace elements had BD-90/90-defined concentrations that were considered to be detections, indicating that SRLs should be established and used to screen data for these constituents. For some of these trace elements $(\mathrm{Cu}$, $\mathrm{Pb}, \mathrm{Ni}, \mathrm{W}, \mathrm{V}$, and $\mathrm{Zn}$ ), the SRLs could be defined directly from the BD-90/90 concentrations determined from the field-blank data because the source(s) of contamination that were inferred for the field blanks were sources that could have affected the environmental samples also. However, for the other trace elements ( $\mathrm{Al}, \mathrm{Ba}, \mathrm{Cr}, \mathrm{Fe}, \mathrm{Hg}, \mathrm{Mn}$, and $\mathrm{Sr}$ ), sources of fieldblank contamination were identified that either could not have affected the groundwater samples or could have affected only the groundwater samples collected during specific times. Additional data for each of these trace elements were evaluated to determine whether the BD-90/90 concentration calculated using all the field blanks was adequate or overly conservative for the purpose of censoring the groundwater sample results. The SRLs were then adjusted accordingly, as explained in the following sections. In one instance $(\mathrm{Hg})$, it was determined that an SRL should be applied only to a specific time period because of the nature of the source of the field-blank contamination. Analytical results less than the SRLs discussed below (and given in table 2) have an unacceptably high likelihood of significant contamination bias and should be remarked as less than or equal to $(\leq)$ the reported value. 


\section{Aluminum (Al)}

Twenty-four of the 86 field blanks ( 28 percent) had detections of aluminum (fig. 4, table 2); detected concentrations ranged from $\mathrm{E} 0.9$ to $63.3 \mu \mathrm{g} / \mathrm{L}$. Of the 16 concentrations that were above the LRL of $1.6 \mu \mathrm{g} / \mathrm{L}, 14$ were detected from April 2005 through February 2006 (shaded on fig. 4). Blank water from NWIS-I Lot No. 80501, used by GAMA during this period, was a suspected source of contamination to the field blanks; this suspicion was based on information from the NWQL (written commun.: USGS NWQL Rapi-Note 06-008, April 2006, and Rapi-Note 06-022, June 2006; James A. Lewis, August 2008). Although this lot of UBW was found to have elevated concentrations of several trace elements ( $\mathrm{Al}$, $\mathrm{Ba}, \mathrm{Cr}, \mathrm{Fe}, \mathrm{Mn}$, and $\mathrm{Sr}$ ), concentrations of aluminum were particularly high, ranging from about 10 to more than $74 \mu \mathrm{g} / \mathrm{L}$ (appendix table A1).

Source-solution blanks collected throughout the study period did not include the period of known blank-water contamination from Lot No. 80501 (April 2005 through February 2006); however, 2 of the 15 source-solution blanks had aluminum detections after this period $(4.2 \mu \mathrm{g} / \mathrm{L}$ on $9 / 13 / 2007$ and $3.9 \mu \mathrm{g} / \mathrm{L}$ on $10 / 29 / 2007$ ), indicating an additional source of contamination possibly associated with laboratory processes or a different lot of blank water. Aluminum was detected in 10 field blanks collected outside of the period of blankwater contamination, at concentrations ranging from E0.9 to $4.0 \mu \mathrm{g} / \mathrm{L}$, indicating that field processes could also have introduced contamination. Aluminum is used in some of the fittings used to collect the groundwater samples; however, the process used to clean the equipment prior to sampling was expected to have prevented or mitigated this potential source from affecting the field blanks and groundwater samples.

The BD-90/90 concentration calculated for all 86 field blanks was $47.5 \mu \mathrm{g} / \mathrm{L}$ (table 2, fig. 4); however, because of the contaminated blank water, the BD-90/90 concentration was recalculated omitting the 18 field blanks from the period of blank-water contamination and was determined to be E1.2 $\mu \mathrm{g} / \mathrm{L}$ for the remaining 68 field blanks (table 2). The BD-90/90 of $47.5 \mu \mathrm{g} / \mathrm{L}$ was not used for the SRL because the contaminated blank water used for some of the field blanks was a source of contamination would not have affected the groundwater samples.

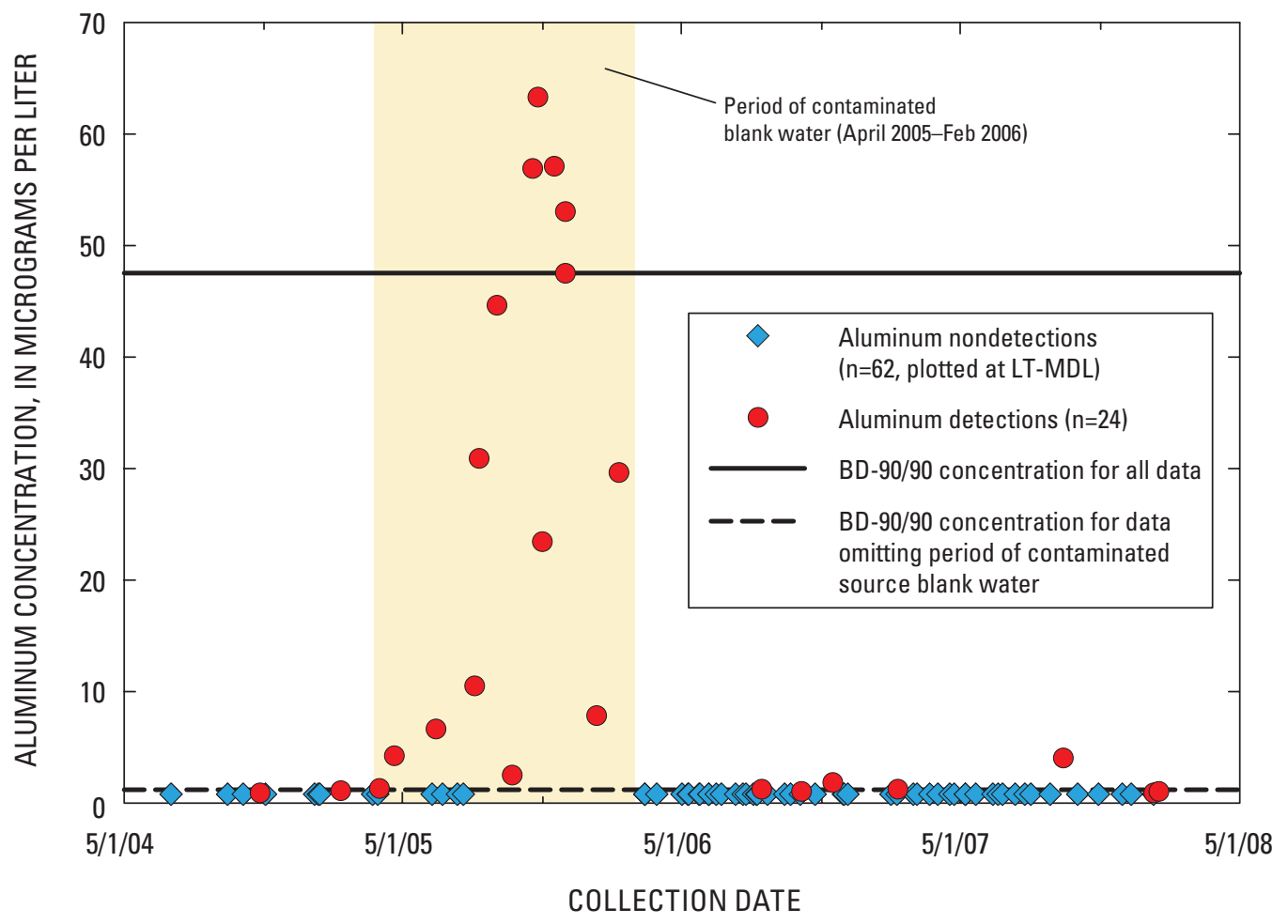

Figure 4. Aluminum (Al) concentrations in field blanks collected from May 2004 through January 2008, plotted in time-series with the BD-90/90 concentration. Nondetections plotted at their long-term method detection limits (LT-MDL). 
Before establishing an SRL from only a partial dataset, sources of contamination not related to the contaminated blank water used April 2005 through February 2006 but that could have affected the results were evaluated. BQS Blind Blank Project data were evaluated to determine the potential for laboratory contamination during the study period. Several blind laboratory blanks (14 of 143) analyzed during the study period had concentrations above the LT-MDL, ranging from 0.8 to $4.2 \mu \mathrm{g} / \mathrm{L}$ (http://bqs.usgs.gov/bbp/BBPICPMS_Fil.html); however, most blanks were at or below the LRL of $1.6 \mu \mathrm{g} / \mathrm{L}$, and the BD-90/90 concentration for the BQS blind blanks was $1.2 \mu \mathrm{g} / \mathrm{L}$ (table 3), the same concentration as that for the 68 field blanks not affected by Lot No. 80501 .

To evaluate the potential effect of low-level carry-over contamination from the blank water to subsequent groundwater samples, all field blanks were paired with their corresponding groundwater samples (those collected immediately following the field blank) and plotted by concentration (fig. 5). Contamination was detected in several field blanks, and the paired concentrations for many of the contaminated

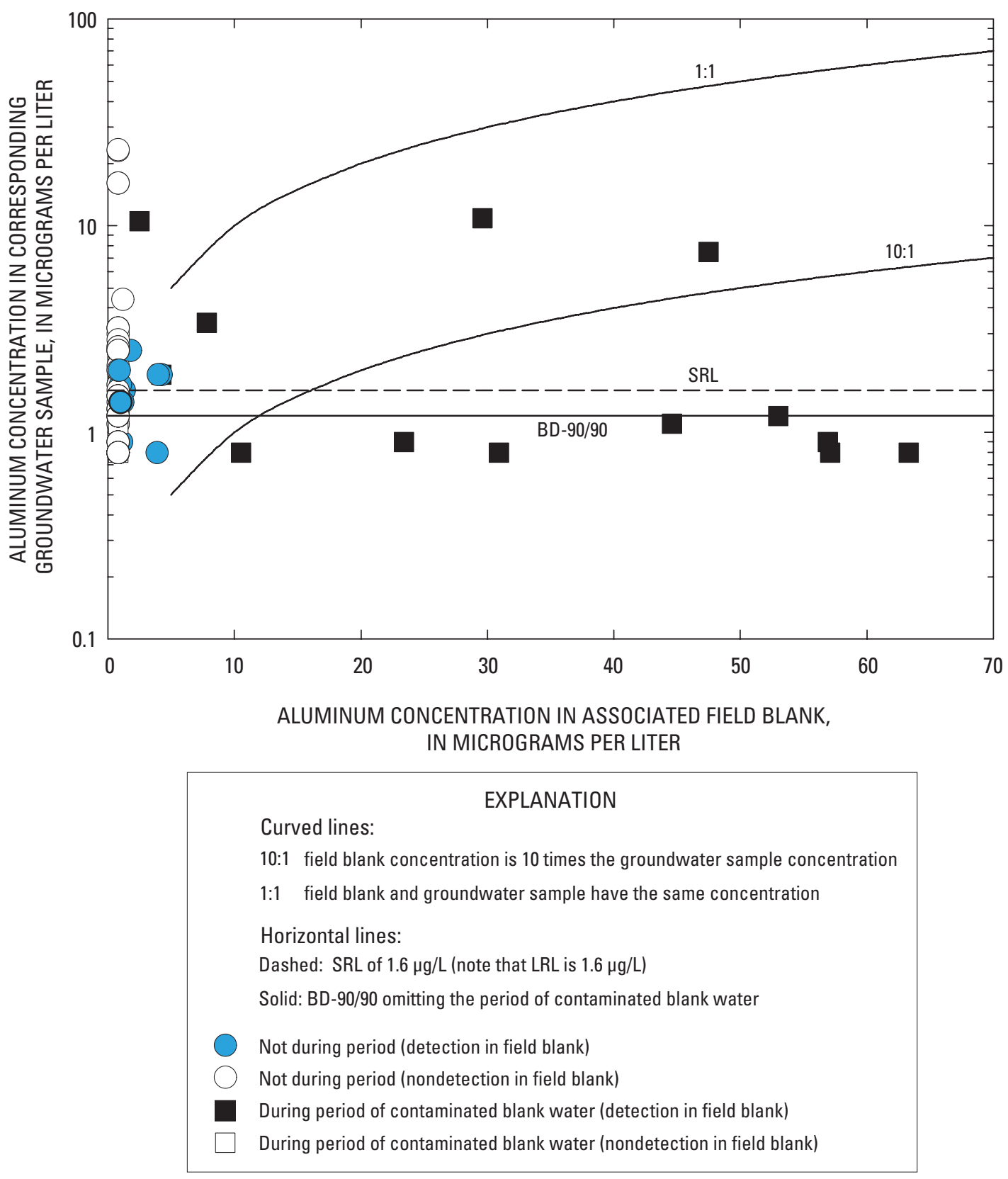

Figure 5. Aluminum (Al) concentrations in field blanks paired with their corresponding groundwater samples collected from May 2004 through January 2008. SRL, study reporting level; LRL, laboratory reporting level; BD-90/90, 90th percentile concentration determined using binomial distribution with a confidence level that is 90 percent or greater. $\mu \mathrm{g} / \mathrm{L}$, microgram per liter. 
field blanks lie below the 10:1 line, which indicates that the field-blank contamination was more than ten times that in the corresponding groundwater sample. For these pairs, incomplete flushing of the contaminated blank water prior to sample collection could have had a measureable effect on the groundwater samples. An SRL of $1.6 \mu \mathrm{g} / \mathrm{L}$ was chosen because this concentration is higher than the concentrations in the groundwater samples for pairs that plotted below the 10:1 line. This SRL is slightly higher than the BD-90/90 concentration in the field blanks when the period of contaminated blank water was omitted (E1.2 $\mu \mathrm{g} / \mathrm{L})$ and the BD-90/90 for the BQS Blind Blank Project data $(1.2 \mu \mathrm{g} / \mathrm{L})$, but was considered to be appropriate for the whole dataset because of the simplicity of adopting a single SRL equal to the LRL of $1.6 \mu \mathrm{g} / \mathrm{L}$ that was used throughout the study period.

This SRL of $1.6 \mu \mathrm{g} / \mathrm{L}$ for aluminum is far below the MCL-CA of $1,000 \mu \mathrm{g} / \mathrm{L}$. Analytical results that are less than $1.6 \mu \mathrm{g} / \mathrm{L}$ (including E-coded values for concentrations that were less than $1.6 \mu \mathrm{g} / \mathrm{L}$ before applying a dilution factor) should be remarked as less than or equal to $(\leq)$ the reported value.

\section{Barium (Ba)}

Twenty-six of 89 field blanks (29 percent) collected for barium had detections (fig. 6, table 2). Barium detections ranged in concentration from E0.04 to $1.5 \mu \mathrm{g} / \mathrm{L}$. Barium was most often detected in the field blanks during the period when the contaminated lot of UBW (NWIS-I Lot No. 80501) was used, April 2005 through February 2006 (shaded on fig. 6, appendix table A1). Barium concentrations in 8 test samples from this lot of blank water ranged from 0.011 to $0.927 \mu \mathrm{g} / \mathrm{L}$, but only 3 were above the LRL of $0.2 \mu \mathrm{g} / \mathrm{L}$; therefore, not all of the contamination in the field blanks, particularly for the concentrations above $0.927 \mu \mathrm{g} / \mathrm{L}$, could be solely attributed to this lot of blank water. The maximum barium concentration $(1.5 \mu \mathrm{g} / \mathrm{L}$ on February 9,2005$)$ in a field blank was not detected during the period of contaminated blank water.

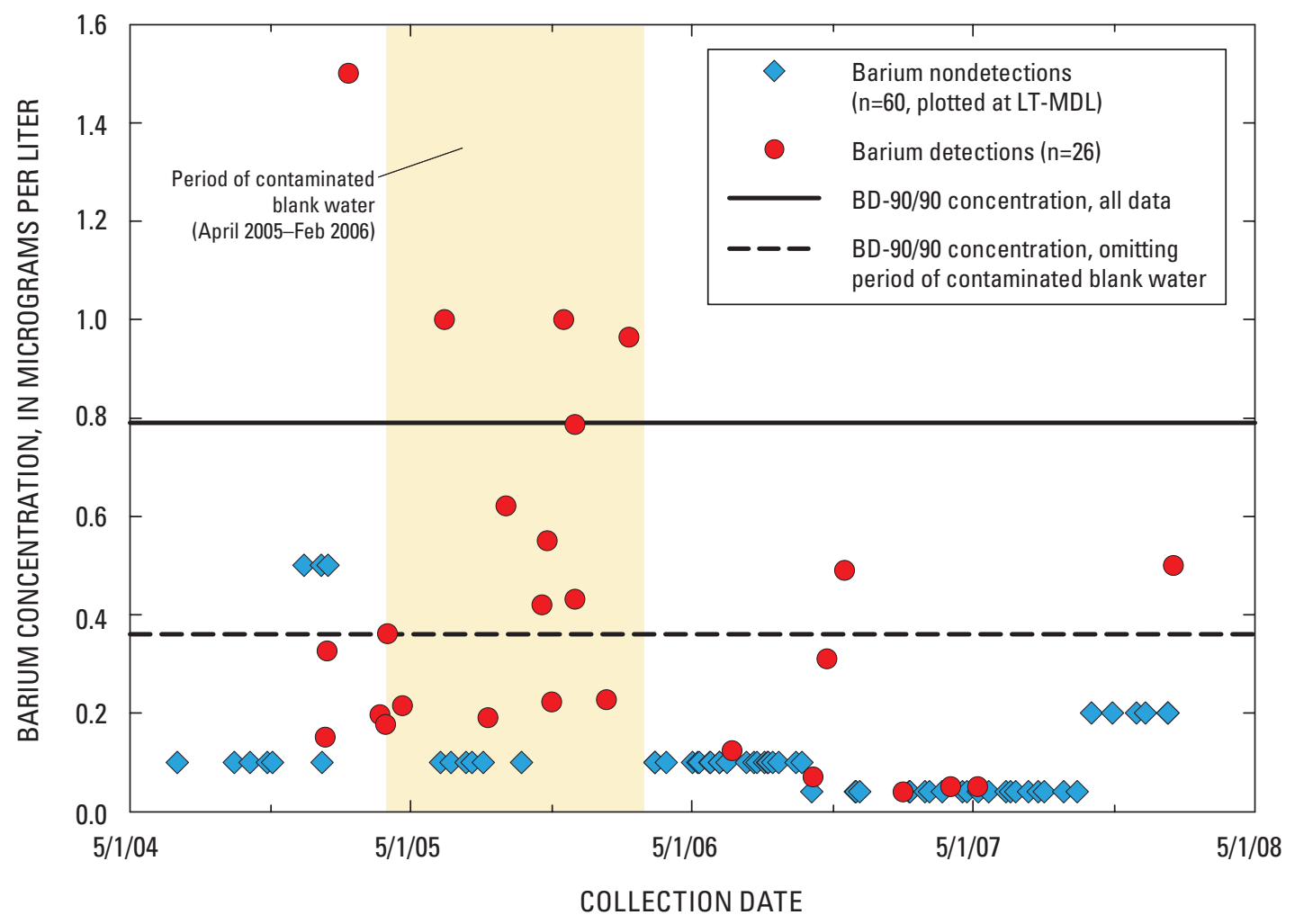

Figure 6. Barium $(\mathrm{Ba})$ concentrations in field blanks collected from May 2004 through January 2008, plotted in time-series with the BD-90/90 concentration (nondetections plotted at their LT-MDLs). BD-90/90, 90th percentile concentration determined using binomial distribution with a confidence level that is 90 percent or greater; LT-MDL, long-term method detection level; n, number of samples. 
The BD-90/90 concentration for barium was $0.79 \mu \mathrm{g} / \mathrm{L}$ if all of the field blanks were used, but was only $0.36 \mu \mathrm{g} / \mathrm{L}$ if the period of known blank-water contamination was omitted (table 2). Additional sources of contamination were considered by evaluating the source-solution blanks and the BQS Blind Blank Project data. No barium was detected in the 15 sourcesolution blanks collected throughout the study period, but the BQS Blind Blank Project data did yield a BD-90/90 concentration of $0.09 \mu \mathrm{g} / \mathrm{L}$ (table 3), which was slightly above the lowest LRL used during the study period $(0.08 \mu \mathrm{g} / \mathrm{L})$. Because alternative sources of barium contamination that could affect the groundwater samples could not be conclusively ruled out, a decision was made to set the SRL at the BD-90/90 concentration of $0.36 \mu \mathrm{g} / \mathrm{L}$ (table 2). This SRL is far below the MCL$\mathrm{CA}$ of $1,000 \mu \mathrm{g} / \mathrm{L}$. Analytical results that are less than 0.36 $\mu \mathrm{g} / \mathrm{L}$ have an unacceptably high likelihood of having contamination bias and should be remarked as less than or equal to $(\leq)$ the reported value.

\section{Chromium ( $\mathrm{Cr}$ )}

Thirty of 86 field blanks ( 35 percent) collected for chromium had detections (fig. 7, table 2). The detected concentrations ranged from E0.02 to $1.2 \mu \mathrm{g} / \mathrm{L}$. An LT-MDL equaling $0.4 \mu \mathrm{g} / \mathrm{L}$ was used initially during the study period, but was lowered to $0.02 \mu \mathrm{g} / \mathrm{L}$ in September 2005 and then raised to $0.06 \mu \mathrm{g} / \mathrm{L}$ in October 2006. Although no systematic temporal pattern was observed in the time-series plot for chromium (fig. 7), many of the concentrations detected in field blanks were reported during the period of the lowest LRL (September 2005 through October 2006), when values as low as $0.02 \mu \mathrm{g} / \mathrm{L}$ could have been reported.

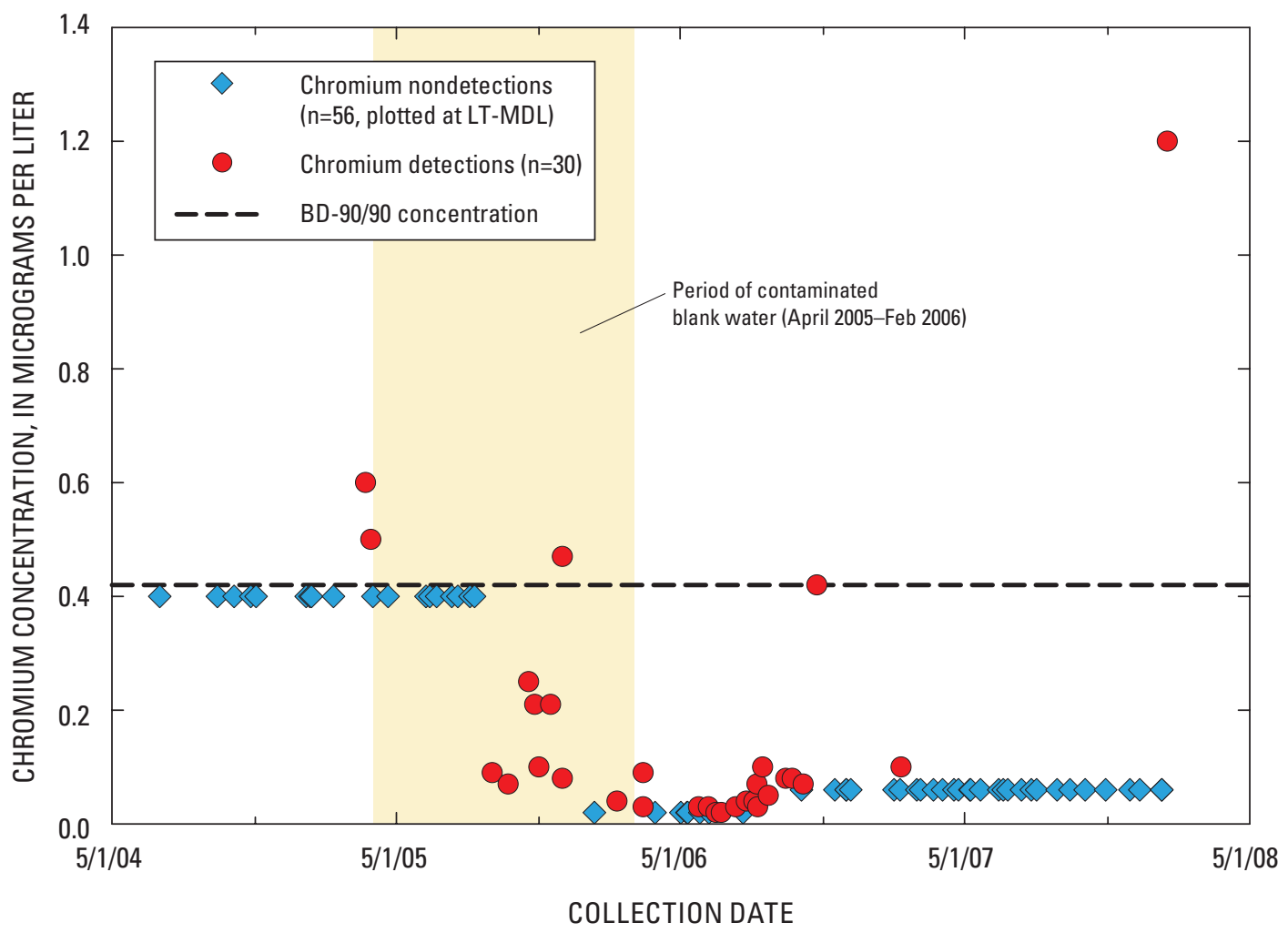

Figure 7. Chromium ( $\mathrm{Cr}$ ) concentrations in field blanks collected from May 2004 through January 2008, plotted in time-series with the BD-90/90 concentration (nondetections plotted at their LT-MDLs). BD-90/90, 90th percentile concentration determined using binomial distribution with a confidence level that is 90 percent or greater; LT-MDL, long-term method detection level; $n$, number of samples. 
The BD-90/90 concentration calculated using data for all of the field blanks was $0.42 \mu \mathrm{g} / \mathrm{L}$ (table 2). Chromium was detected in 2 of 15 source-solution blanks, both at a concentration of E0.3 $\mu \mathrm{g} / \mathrm{L}$ measured on June 6, 2006 (collected in different locations). Although this concentration was similar to the concentrations detected in many of the field blanks, the detection frequency for the source-solution blanks (13 percent) was lower than that for the field blanks (35 percent). Chromium concentrations reported in UBW used to collect the source-solution and field blanks ranged from -0.119 to $0.830 \mu \mathrm{g} / \mathrm{L}$ (appendix table A1), including 4 concentrations above the LRL for a single lot of UBW (NWIS-I Lot No. 80501) that was in use from April 2005 through February 2006; however, these blank-water results do not fully account for the range in chromium concentrations in field blanks collected outside of this period. The BD-90/90 concentration for the BQS Blind Blank Project data was $0.06 \mu \mathrm{g} / \mathrm{L}$ (table 3), indicating that systematic laboratory contamination was not a major source of chromium. Results from the source-solution blanks, blank-water certification information, and the BQS Blind Blank Project data suggest that neither contamination of the source-solution water nor systematic laboratory contamination can account for the all of the chromium detected in field blanks. Therefore, a field component was likely.

One potential source of the chromium was the stainless steel used in some of the pumps and fittings used to collect the samples. The equipment cleaning and rinsing procedures described previously should minimize this potential source of chromium to the field blanks and groundwater samples that come in contact with equipment during sampling. The BD-90/90 concentration was recalculated, omitting the field blanks from the period of known blank-water contamination to isolate the potential contamination bias caused by field sources, and the result was $0.42 \mu \mathrm{g} / \mathrm{L}$ - the same as the result that had been obtained using all of the data (table 2). To ensure that the groundwater sample results would not be unduly affected by false positives caused by extrinsic contamination, an SRL was set at the BD-90/90 concentration of $0.42 \mu \mathrm{g} / \mathrm{L}$ (table 2). This SRL is markedly below the MCL-CA, $50 \mu \mathrm{g} / \mathrm{L}$. Analytical results for chromium that are less than $0.42 \mu \mathrm{g} / \mathrm{L}$ should be remarked as less than or equal to $(\leq)$ the reported value.

\section{Copper (Cu)}

Twenty-two of 86 field blanks (26 percent) collected for copper had detections (fig. 8, table 2). These detections ranged in concentration from E0.2 $\mu \mathrm{g} / \mathrm{L}$ to $3.2 \mu \mathrm{g} / \mathrm{L}$. The BD-90/90 concentration for copper in the field blanks was $1.7 \mu \mathrm{g} / \mathrm{L}$, which was above the highest LRL used during the study period $(1 \mu \mathrm{g} / \mathrm{L})$. No systematic temporal pattern was observed in the time-series plot for copper (fig. 8).

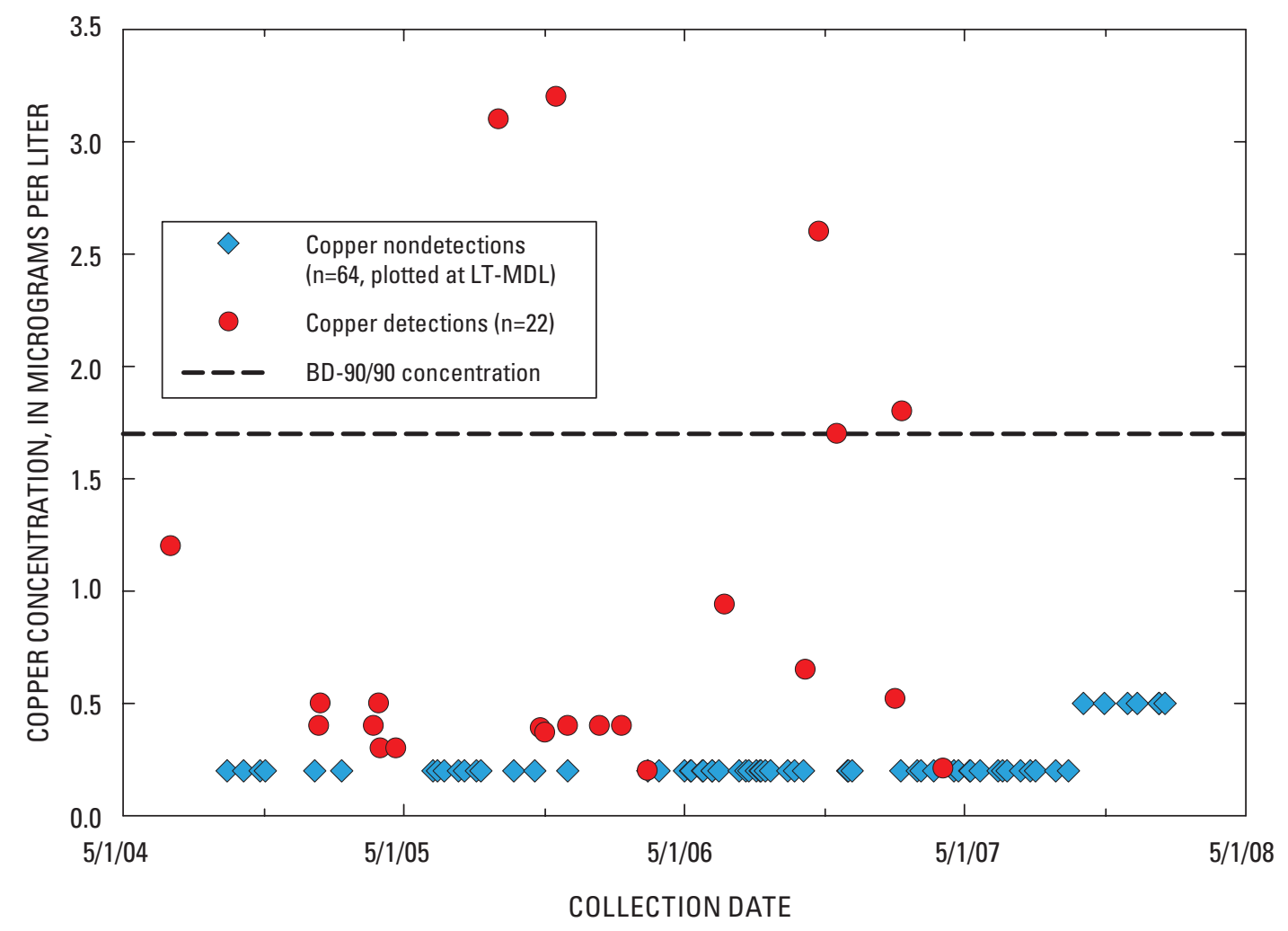

Figure 8. Copper (Cu) concentrations in field blanks collected from May 2004 through January 2008, plotted in time-series with the BD-90/90 concentration (nondetections plotted at their LT-MDLs). BD-90/90, 90th percentile concentration determined using binomial distribution with a confidence level that is 90 percent or greater; LT-MDL, long-term method detection level; $\mathrm{n}$, number of samples. 
Laboratory blind blanks reported for the BQS Blind Blank Project had very few instances of contamination by copper above the LRL, with no systematic pattern throughout the study period; the BD-90/90 for these blanks was $0.44 \mu \mathrm{g} / \mathrm{L}$ (table 3), which does not account for the $\mathrm{Cu}$ contamination above $0.44 \mu \mathrm{g} / \mathrm{L}$ seen in the field blanks. Although copper was not detected in any of the 15 source-solution blanks, some bottles of UBW and/or IBW contained copper above the LT-MDL and even above the LRL, as was observed in UBW NWIS-I Lot No. 80502, $0.459 \mu \mathrm{g} / \mathrm{L}$, analyzed in March 2005 (appendix table A1). Copper is used in copper and brass fittings used to collect the samples; however, equipment-cleaning procedures should minimize the likelihood of transfer into the field blanks or groundwater samples. Because it was not possible to attribute all of the copper contamination in the field blanks to contamination in the blank water, a conservative decision was made to set an SRL at the BD-90/90 concentration of $1.7 \mu \mathrm{g} / \mathrm{L}$ (table 2). This SRL is far below the AL-US of $1,300 \mu \mathrm{g} / \mathrm{L}$. Analytical results that are less than $1.7 \mu \mathrm{g} / \mathrm{L}$ should be remarked as less than or equal to $(\leq)$ the reported value.

\section{Iron (Fe)}

Ten of 86 field blanks (12 percent) collected for iron had detections (fig. 9, table 2). These detections ranged in concentration from E4 to $36 \mu \mathrm{g} / \mathrm{L}$. The BD-90/90 concentration calculated using all of the field blanks was $21 \mu \mathrm{g} / \mathrm{L}$, which is close to three times the LRLs used during the study period (6 and $8 \mu \mathrm{g} / \mathrm{L}$ ).

Eight of the 10 detections of iron in field blanks occurred during the period of April 2005 through February 2006 (shaded on fig. 9), when contaminated blank water from NWIS-I Lot No. 80501 was sometimes used (appendix table A1). Although this lot of UBW was found to have elevated concentrations of several trace elements ( $\mathrm{Al}, \mathrm{Ba}, \mathrm{Cr}, \mathrm{Fe}, \mathrm{Mn}$, and $\mathrm{Sr}$ ), the iron concentrations were particularly inconsistent throughout the lot. Only 3 of 8 test samples of this UBW had iron concentrations above either the LT-MDL of $3 \mu \mathrm{g} / \mathrm{L}$ or the LRL of $6 \mu \mathrm{g} / \mathrm{L}$ (appendix table A1); however, these iron concentrations, $80.90,42.27$, and $34.05 \mu \mathrm{g} / \mathrm{L}$, in the blank water could explain the range of concentrations of iron detected in the field blanks during this period (fig. 8). In addition, the frequency of detections of iron concentrations above the LRL in NWIS-I Lot No. 80501 (38 percent) was similar to the frequency for the field blanks during this period ( 8 of 18 field blanks or 44 percent). Iron was not detected in any of the 15 source-solution blanks collected throughout the study period.

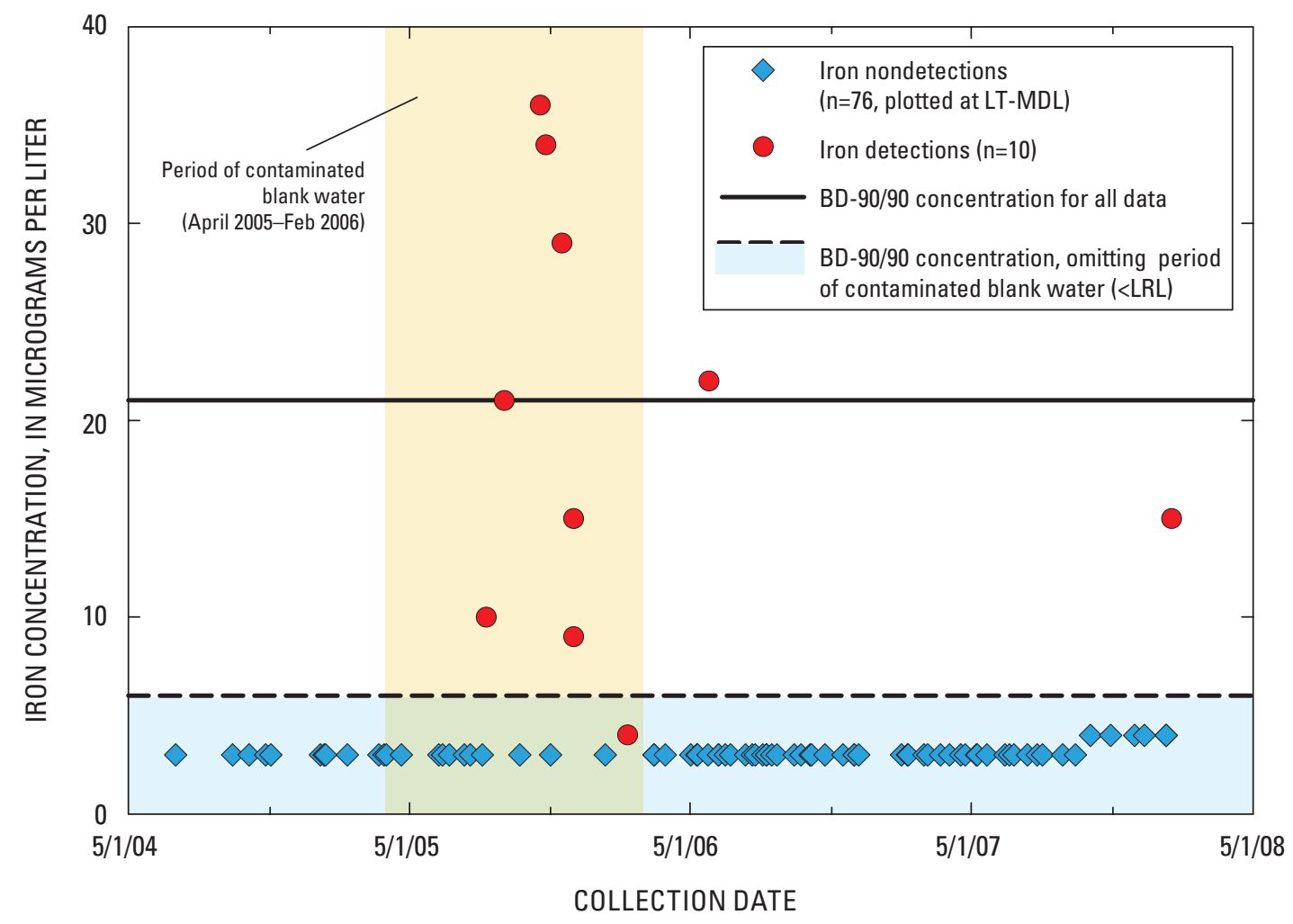

Figure 9. Iron (Fe) concentrations in field blanks collected from May 2004 through January 2008, plotted in time-series with the BD-90/90 concentration (nondetections plotted at their LT-MDLs). BD-90/90, 90th percentile concentration determined using binomial distribution with a confidence level that is 90 percent or greater; LT-MDL, long-term method detection level; n, number of samples. 
Additional sources of contamination were considered with respect to their potential effects on the groundwater sample results. The BQS Blind Blank Project data indicated no laboratory contamination problems for iron that could explain the additional detections that were observed in the field blanks; the BQS Blind Blank Project BD-90/90 for iron was $2.6 \mu \mathrm{g} / \mathrm{L}$ (table 3). The stainless-steel Grundfos ${ }^{\circledR}$ submersible pump used to sample monitoring wells was evaluated as a potential source of the iron contamination; however, only 2 of the 10 contaminated field blanks $(29 \mu \mathrm{g} / \mathrm{L}$ on November 15 , 2005 , and $15 \mu \mathrm{g} / \mathrm{L}$ on January 16,2008 ) were collected in conjunction with monitoring wells, and the detection on November 15, 2005, might be explained by the contaminated UBW. Iron is also in many of the fittings and equipment used to collect the field blanks and the groundwater samples, including those made of stainless or galvanized steel, as well as in the environment surrounding the field sites (rust on well casings, etc.); however, the procedures used to clean the sampling equipment and the hose bib at the attachment point would tend to mitigate contamination from these sources.

Since only 2 of the 10 detections of iron in the 86 field blanks occurred outside of the period of known UBW contamination, and since no systematic sources of contamination were identified outside of this period, the BD-90/90 concentration was recalculated for the 68 field blanks collected outside of the period of UBW contamination and was found to be $<6 \mu \mathrm{g} / \mathrm{L}$, a nondetection. After considering the low-level contamination indicated by the BQS Blind Blank Project data (table 3) and the analyses of blank water prepared by the NWQL (appendix table A1), a conservative decision was made to establish an SRL of $6 \mu \mathrm{g} / \mathrm{L}$ for iron. Analytical results that are less than $6 \mu \mathrm{g} / \mathrm{L}$ should be remarked as less than or equal to (" $\leq$ ") the reported value.

\section{Lead $(\mathrm{Pb})$}

Twenty-two of 86 field blanks (26 percent) collected for lead had detections (fig. 10, table 2). These detections ranged in concentration from E0.04 $\mu \mathrm{g} / \mathrm{L}$ to $15.4 \mu \mathrm{g} / \mathrm{L}$. One concentration, $15.4 \mu \mathrm{g} / \mathrm{L}$, measured in a field blank collected on March 31, 2005, was slightly above the AL-US of $15 \mu \mathrm{g} / \mathrm{L}$; the concentration in the groundwater sample collected immediately after this field blank was V2.04 $\mu \mathrm{g} / \mathrm{L}$. This groundwater sample result was coded by project staff with a "V" to indicate that this constituent had been detected in an associated blank and could be the result of contamination bias from an understood source. The second highest concentration of lead $(2.99 \mu \mathrm{g} / \mathrm{L})$ was measured in a field blank collected on April 20, 2005. The BD-90/90 concentration for lead based on the field-blank data was only $0.65 \mu \mathrm{g} / \mathrm{L}$, which was above the highest LRL used during the study period $(0.12 \mu \mathrm{g} / \mathrm{L}$, table 2$)$.

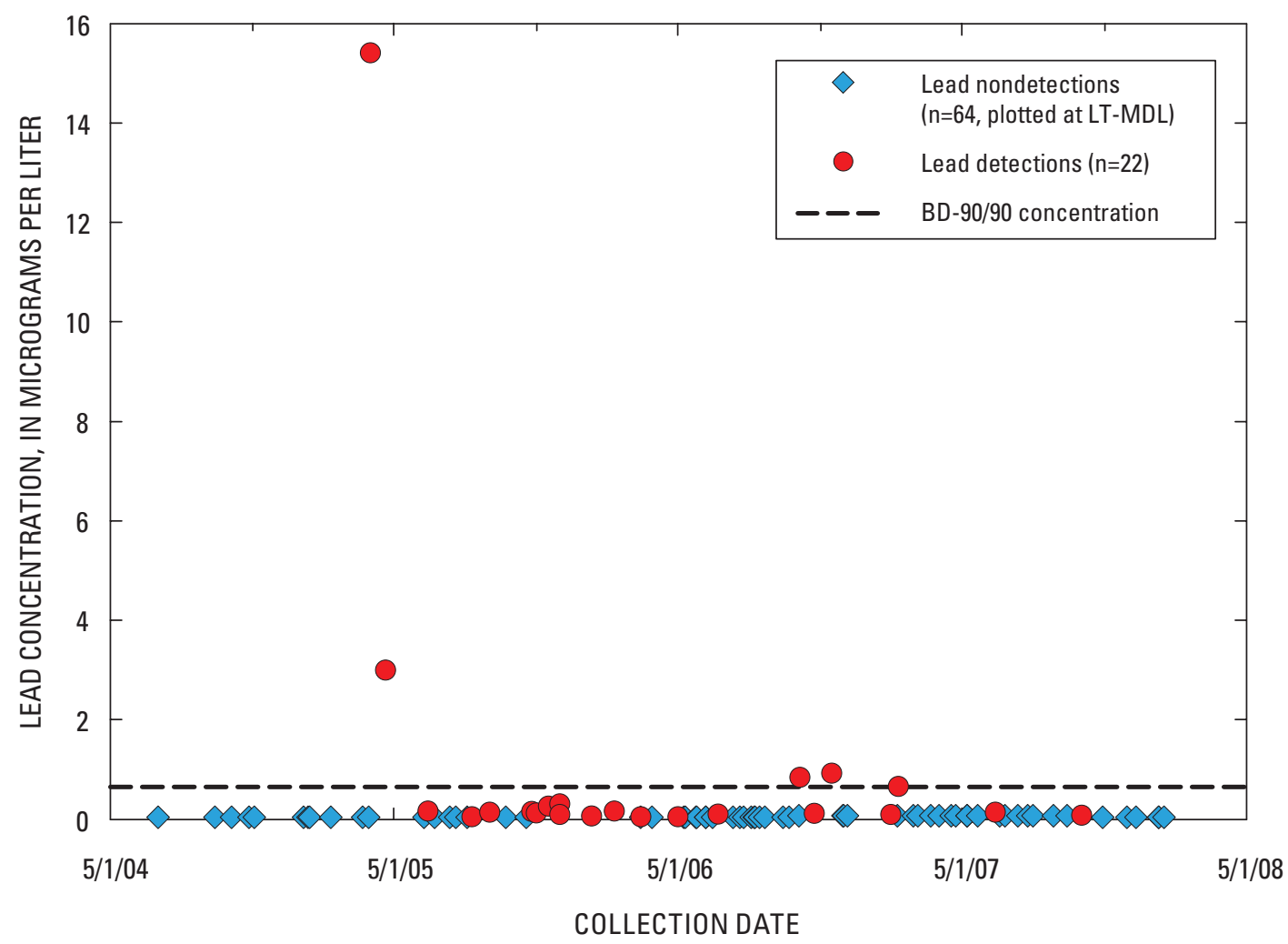

Figure 10. Lead $(\mathrm{Pb})$ concentrations in field blanks collected from May 2004 through January 2008, plotted in time-series with the BD-90/90 concentration (nondetections plotted at their LT-MDLs). BD-90/90, 90th percentile concentration determined using binomial distribution with a confidence level that is 90 percent or greater; LT-MDL, long-term method detection level; n, number of samples. 
The two highest concentrations of lead in field blanks, mentioned above, were likely caused by a specific set of metal fittings used to connect to two wells during the spring of 2005 (according to the recollections of field staff); however, it was not common practice to document every metal fitting used for every well. The time-series plot (fig. 10) shows that there is no persistent pattern of contamination beyond this narrow period in the spring of 2005. In addition, there were no detections of lead in the 15 source-solution blanks and no laboratory contamination near or above $0.65 \mu \mathrm{g} / \mathrm{L}$ according to the BQS Blind Blank Project data (BD-90/90 of $0.04 \mu \mathrm{g} / \mathrm{L}$, table 3). For these reasons, an SRL of $0.65 \mu \mathrm{g} / \mathrm{L}$ was established for lead (table 2). This SRL is far below the AL-US of $15 \mu \mathrm{g} / \mathrm{L}$. Analytical results for lead that are less than $0.65 \mu \mathrm{g} / \mathrm{L}$ should be remarked as less than or equal to $(\leq)$ the reported value.

\section{Manganese (Mn)}

Fourteen of 86 field blanks (16 percent) collected for manganese had detections (fig. 11, table 2). These manganese detections ranged in concentration from E0.1 to $1.3 \mu \mathrm{g} / \mathrm{L}$, and seven were equal to or above the LRL of $0.2 \mu \mathrm{g} / \mathrm{L}$ that was used throughout the study period. The BD-90/90 concentra- tion for manganese calculated using the field-blank data was $0.2 \mu \mathrm{g} / \mathrm{L}$.

Although manganese was not detected in any of the 15 source-solution blanks, it was one of the contaminants found in blank water from NWIS-I Lot No. 80501 analyzed at the NWQL. Only 3 of 8 test samples of this blank water had concentrations above either the LT-MDL or LRL (appendix table A1); the maximum concentration was $0.455 \mu \mathrm{g} / \mathrm{L}$. Although half of the detections in the field blanks occurred during the period when the contaminated blank water was used (April 2005 through February 2006, shaded on fig. 11), this source does not explain the 7 sporadic detections that occurred outside the period of known contaminated UBW.

Additional sources of contamination were considered with respect to their potential effects on the groundwater sample data. Since the BQS Blind Blank Project data indicated no widespread laboratory contamination above the LRL (the BD-90/90 concentration of $0.08 \mu \mathrm{g} / \mathrm{L}$ was below one-half of the LRL, table 3), an unknown field component was likely. Manganese is used in steel and other metal alloys that could be used in sampling equipment. Although the equipment cleaning procedures would tend to mitigate or prevent contamination from the equipment itself, it could not be ruled out.

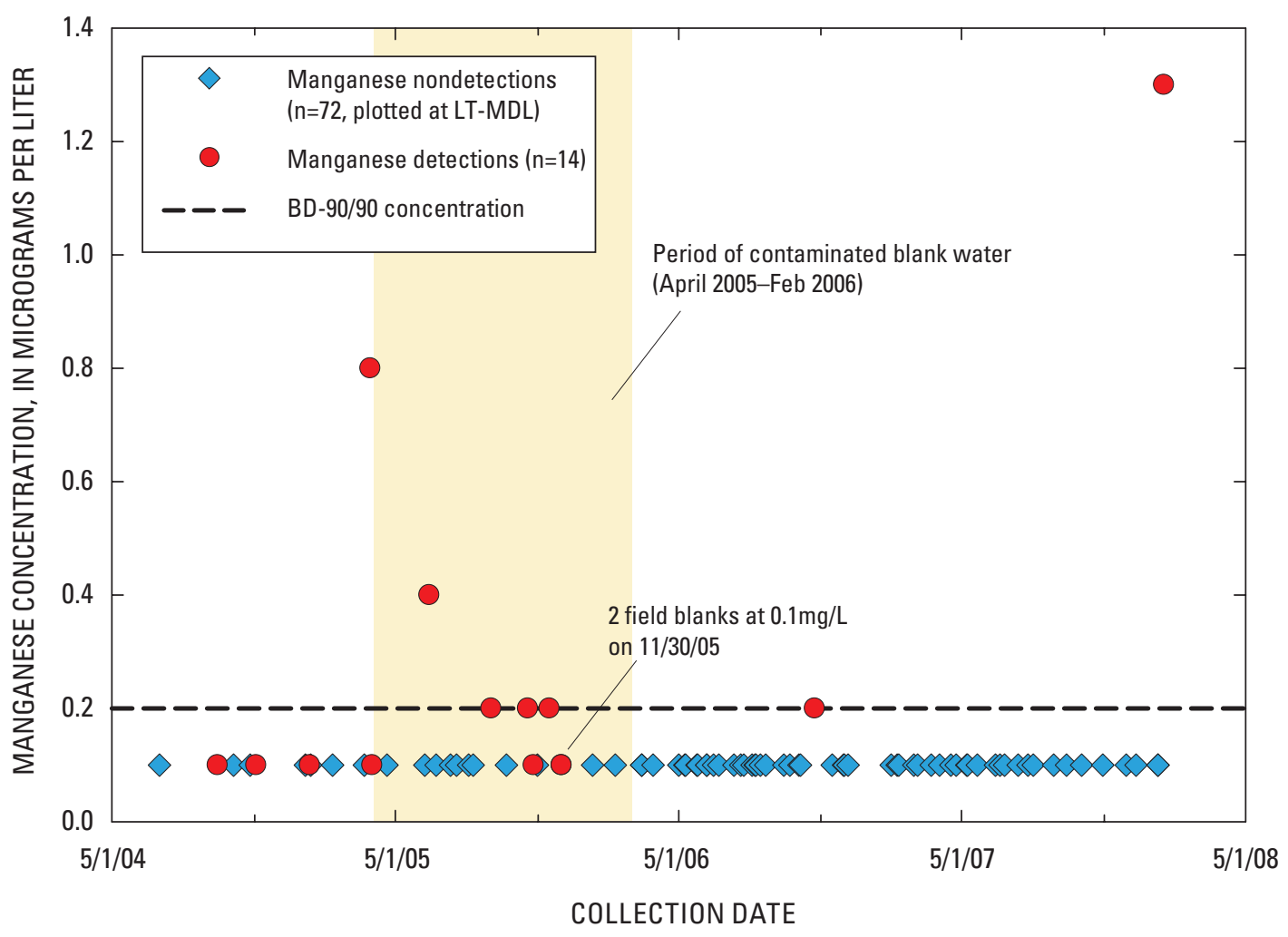

Figure 11. Manganese (Mn) concentrations in field blanks collected from May 2004 through January 2008, plotted in time-series with the BD-90/90 concentration (nondetections plotted at their LT-MDLs). BD-90/90, 90th percentile concentration determined using binomial distribution with a confidence level that is 90 percent or greater; LT-MDL, long-term method detection level; $n$, number of samples. 
Since the highest concentrations of manganese in field blanks were detected outside of the period of known UBW contamination $(0.8 \mu \mathrm{g} / \mathrm{L}$ on March 29,2005 , and $1.3 \mu \mathrm{g} / \mathrm{L}$ on January 16,2008 ) and since the contamination from equipment or other field sources could affect groundwater samples irrespective of which blank water was used, none of the field blanks were omitted from the calculation. (For manganese, the contaminated UBW was less dominant as a source of detections in field blanks than of the other trace elements that were detected in NWIS-I Lot No. 80501.) The BD-90/90 concentration calculated omitting field blanks from the period of known UBW contamination (E0.1 $\mu \mathrm{g} / \mathrm{L}$ ) was similar to the BD-90/90 concentration calculated using all of the field-blank concentrations $(0.2 \mu \mathrm{g} / \mathrm{L})$; therefore, a conservative decision was made to set the SRL for manganese to $0.2 \mu \mathrm{g} / \mathrm{L}$. This SRL is far below the SMCL-CA of $50 \mu \mathrm{g} / \mathrm{L}$. Analytical results for manganese that are less than $0.2 \mu \mathrm{g} / \mathrm{L}$ should be remarked as less than or equal to $(\leq)$ the reported value.

\section{Mercury $(\mathrm{Hg})$}

Five of 63 field blanks ( 8 percent) collected for mercury had detections (fig. 12, table 2). The detected concentrations ranged from E0.006 to $0.016 \mu \mathrm{g} / \mathrm{L}$. The BD-90/90 concentration for mercury calculated using all 63 field blanks was $\mathrm{E} 0.009 \mu \mathrm{g} / \mathrm{L}$. Mercury was not detected in the three source-solution blanks that were analyzed for this constituent. Blank-water certificates showed a median concentration of $0.000 \mu \mathrm{g} / \mathrm{L}$ and a maximum concentration of $0.004 \mu \mathrm{g} / \mathrm{L}$, indicating that mercury generally was not present in the blank water (appendix table A1). The BQS Blind Blank Project data (http://bqs.usgs.gov/bbp/BBPMercury.html) indicated a period of slight contamination bias from October 2006 through at least January 2008 that was noted as being caused by "sample bottle contamination." The BQS Blind Blank Project uses sample bottles from the same source as the GAMA Program; thus these bottles are the likely source of the five detections of mercury in the field blanks collected from October 2006 through November 2007 (fig. 12).

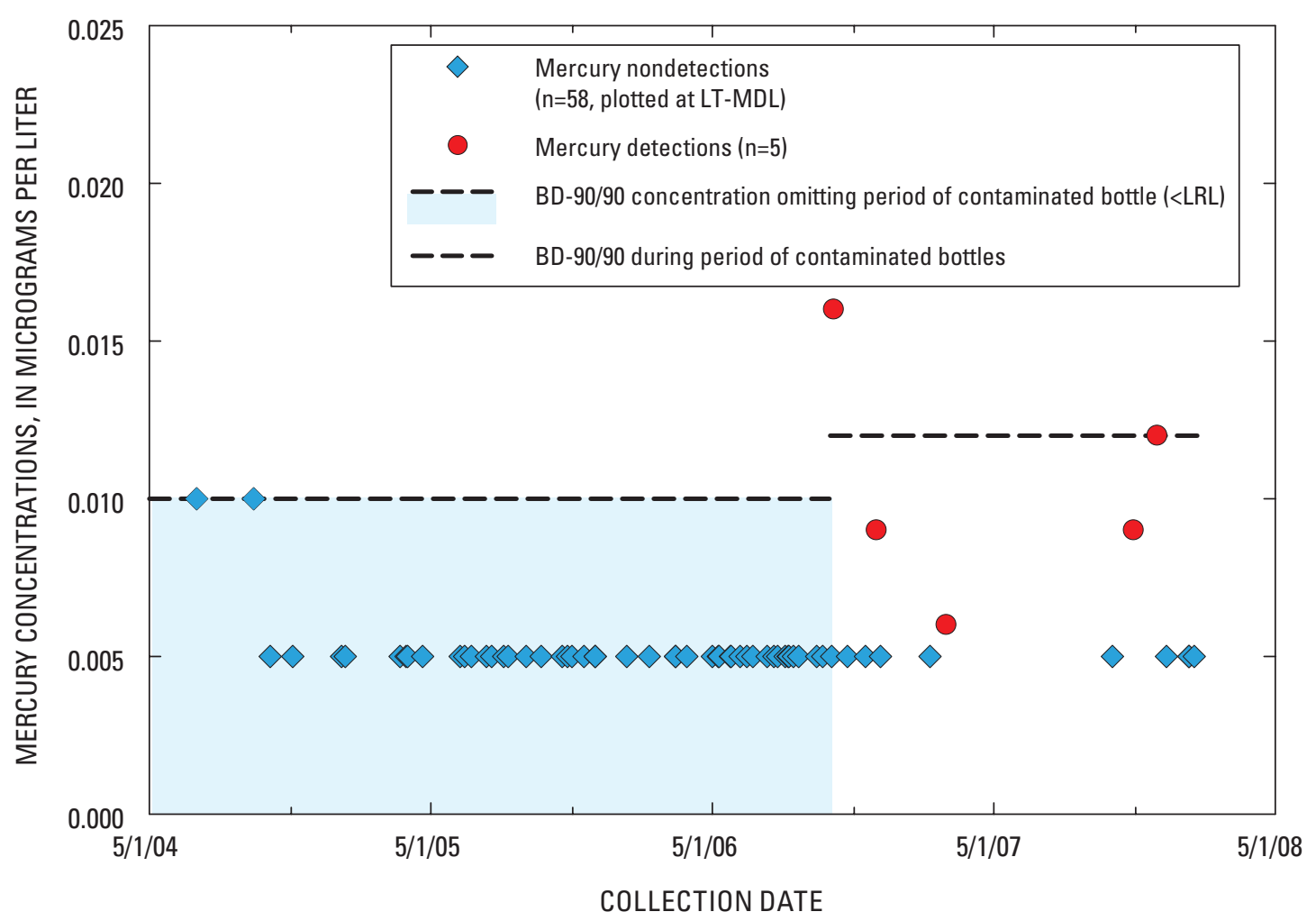

Figure 12. Mercury $(\mathrm{Hg})$ concentrations in field blanks collected from May 2004 through January 2008, plotted in time-series with the BD-90/90 concentration (nondetections plotted at their LT-MDLs). BD-90/90, 90th percentile concentration determined using binomial distribution with a confidence level that is 90 percent or greater; LT-MDL, long-term method detection level; $\mathrm{n}$, number of samples. 
Dividing the field-blank data into pre-October-2006 and post-October-2006 periods resulted in a BD-90/90 concentration of $<0.01 \mu \mathrm{g} / \mathrm{L}$ (equal to the LRL) for the data collected from May 2004 through September 2006 (table 2). The BD90/90 concentration could not be calculated for the 15 field blanks collected from October 2006 through January 2008 because there were too few samples to allow calculation at 90 -percent confidence. There was only 80 -percent confidence that the $14^{\text {th }}$ ranked field blank represented the $80^{\text {th }}$ percentile of the trace-element data; this calculation resulted in a BD$80 / 80$ concentration of $0.012 \mu \mathrm{g} / \mathrm{L}$ (table 3 ). On the basis of these calculations, no SRL was needed for May 2004 through September 2006, and an SRL of $0.012 \mu \mathrm{g} / \mathrm{L}$ was established for October 2006 through January 2008 (table 2). The timelimited SRL, $0.012 \mu \mathrm{g} / \mathrm{L}$, is far below the MCL-US, $2 \mu \mathrm{g} / \mathrm{L}$, for mercury. Analytical results below $0.012 \mu \mathrm{g} / \mathrm{L}$ for groundwater samples collected from October 2006 through January 2008 should be remarked as less than or equal to $(\leq)$ the reported value.

\section{Nickel (Ni)}

Twenty-six of 86 field blanks ( 30 percent) collected for nickel had detections (fig. 13, table 2). The detections ranged in concentration from E0.03 to $1.1 \mu \mathrm{g} / \mathrm{L}$ and had no clear temporal pattern on the time-series plot (fig. 13). The BD-90/90 concentration for nickel was $0.36 \mu \mathrm{g} / \mathrm{L}$. Nickel was not detected in any of the 15 source-solution blanks. No concentration of nickel was detected above the LRLs of 0.06 or $0.20 \mu \mathrm{g} / \mathrm{L}$ in any of the blank water analyzed by the NWQL (appendix table A1). The BQS Blind Blank Project data did not indicate any systematic laboratory contamination for nickel, as supported by the BQS BD-90/90 of $0.056 \mu \mathrm{g} / \mathrm{L}$ (table 3).

Some of the metal fittings used to collect groundwater samples contain nickel. It is possible that sporadic low-level nickel contamination affected field blanks and groundwater samples alike; therefore, an SRL was established at the BD90/90 concentration of $0.36 \mu \mathrm{g} / \mathrm{L}$ (table 2). This SRL of $0.36 \mu \mathrm{g} / \mathrm{L}$ is far below the MCL-US of $100 \mu \mathrm{g} / \mathrm{L}$. Analytical results that are below $0.36 \mu \mathrm{g} / \mathrm{L}$ for nickel should be remarked as less than or equal to $(\leq)$ the reported value.

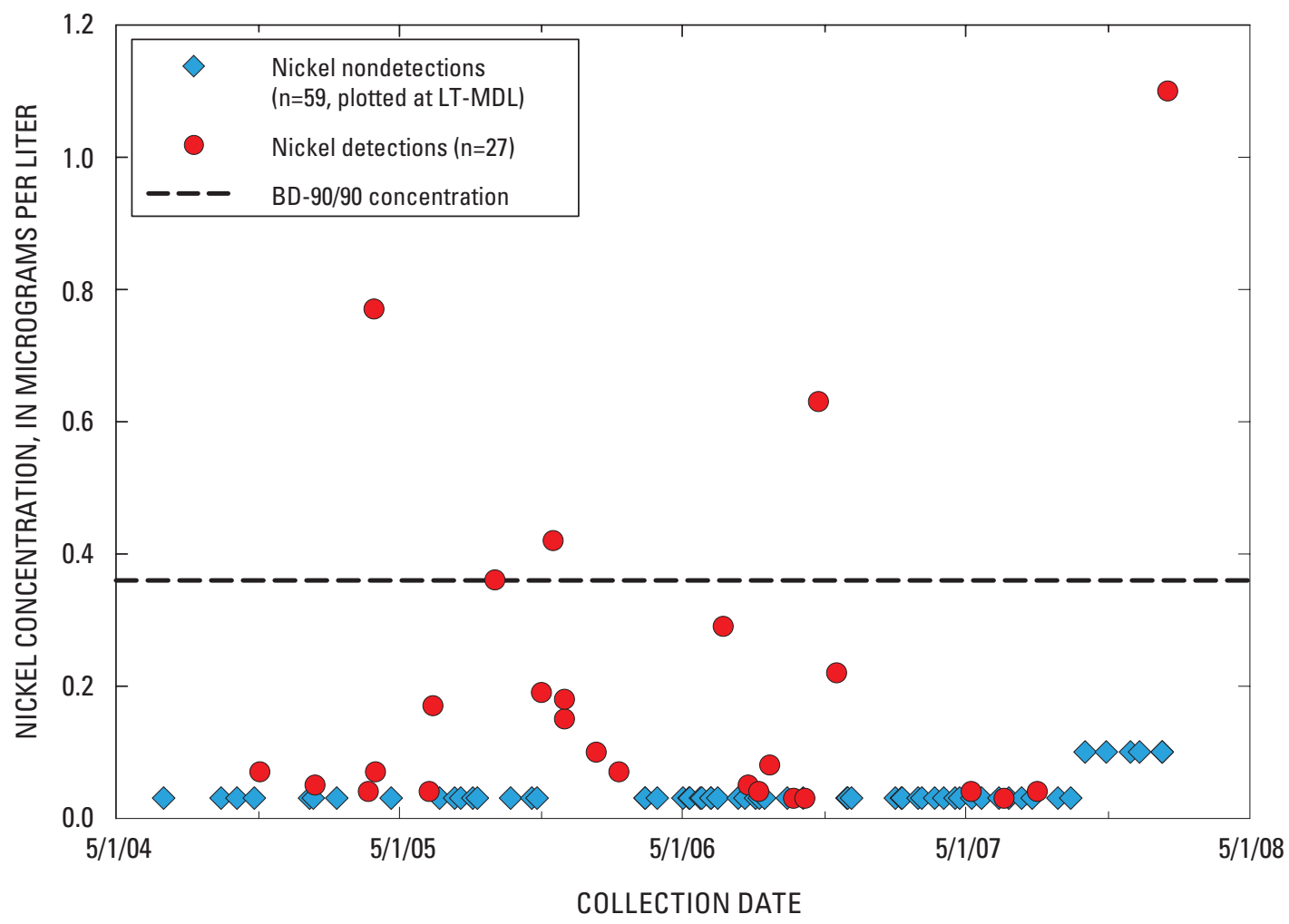

Figure 13. Nickel (Ni) concentrations in field blanks collected from May 2004 through January 2008, plotted in time-series with the BD-90/90 concentration (nondetections plotted at their LT-MDLs). BD-90/90, 90th percentile concentration determined using binomial distribution with a confidence level that is 90 percent or greater; LT-MDL, long-term method detection level; n, number of samples. 


\section{Strontium (Sr)}

Fourteen of 86 field blanks (16 percent) collected for strontium had detections (fig. 14, table 2). These detections ranged in concentration from $\mathrm{E} 0.29$ to an anomalously high $4.42 \mu \mathrm{g} / \mathrm{L}$ in a field blank collected on June 13, 2005. The BD-90/90 concentration calculated using the field blanks was $0.99 \mu \mathrm{g} / \mathrm{L}$. This concentration was above the highest LRL used during the study period $(0.8 \mu \mathrm{g} / \mathrm{L})$.

The BQS Blind Blank Project data did not indicate any systematic laboratory contamination for strontium (BQS BD-90/90 of $0.22 \mu \mathrm{g} / \mathrm{L}$, table 3), and strontium was not detected in any of the 15 source-solution blanks. Six of 8 test samples of UBW analyzed by the NWQL had concentrations of strontium above either the LT-MDL or LRL; these included 5 of the 8 test samples from NWIS Lot No. 80501 (appendix table A1). Lot 80501 of UBW, used from April 2005 through February 2006, was reported to have been contaminated by certain trace elements leaching from the glass bottles. The concentration range in this lot of UBW ( 0.030 to $1.428 \mu \mathrm{g} / \mathrm{L}$ ) brackets the detected concentrations of E0.29 to $1.15 \mu \mathrm{g} / \mathrm{L}$ in field blanks collected during that period except for the $4.42 \mu \mathrm{g} / \mathrm{L}$ in the field blank collected on June 13, 2005 (fig. 14). Despite the variability of the contamination in NWIS Lot No. 80501, the distribution of concentrations found in the UBW (the maximum was $1.428 \mu \mathrm{g} / \mathrm{L}$ ) can explain only part of the $4.42 \mu \mathrm{g} / \mathrm{L}$ found in one of the groundwater samples, which implies a second source of contamination related to field processes. Detections of strontium in four additional field blanks collected outside of the period of known UBW contamination further affirmed the likelihood of a field source of contamination. The BD-90/90 concentration calculated for strontium omitting the period of known UBW contamination was E0.32 $\mu \mathrm{g} / \mathrm{L}$ (table 2).

Strontium concentrations in groundwater samples tend to be high relative to those of other trace elements. The $90^{\text {th }}$ percentile concentration for groundwater samples collected for GAMA from May 2004 through June 2007 was about $990 \mu \mathrm{g} / \mathrm{L}$. The maximum concentration was $23,600 \mu \mathrm{g} / \mathrm{L}$. Therefore, even a minimal amount of 0.1 percent carry-over contamination from a groundwater sample could explain a BD-90/90 concentration of at least $0.99 \mu \mathrm{g} / \mathrm{L}$ in as many as 10 percent of the field blanks. Because it was not possible to rule out carry-over contamination in the field, the SRL was established at the BD90/90 concentration of $0.99 \mu \mathrm{g} / \mathrm{L}$. This SRL is far below the HAL-US of 4,000 $\mu \mathrm{g} / \mathrm{L}$ for strontium. Analytical results that are less than $0.99 \mu \mathrm{g} / \mathrm{L}$ should be remarked as less than or equal to $(\leq)$ the reported value. Likely, the SRL set at this concentration would be rarely applied, if ever, given that all the groundwater samples collected to date have had concentrations of strontium at or above $4.0 \mu \mathrm{g} / \mathrm{L}$.

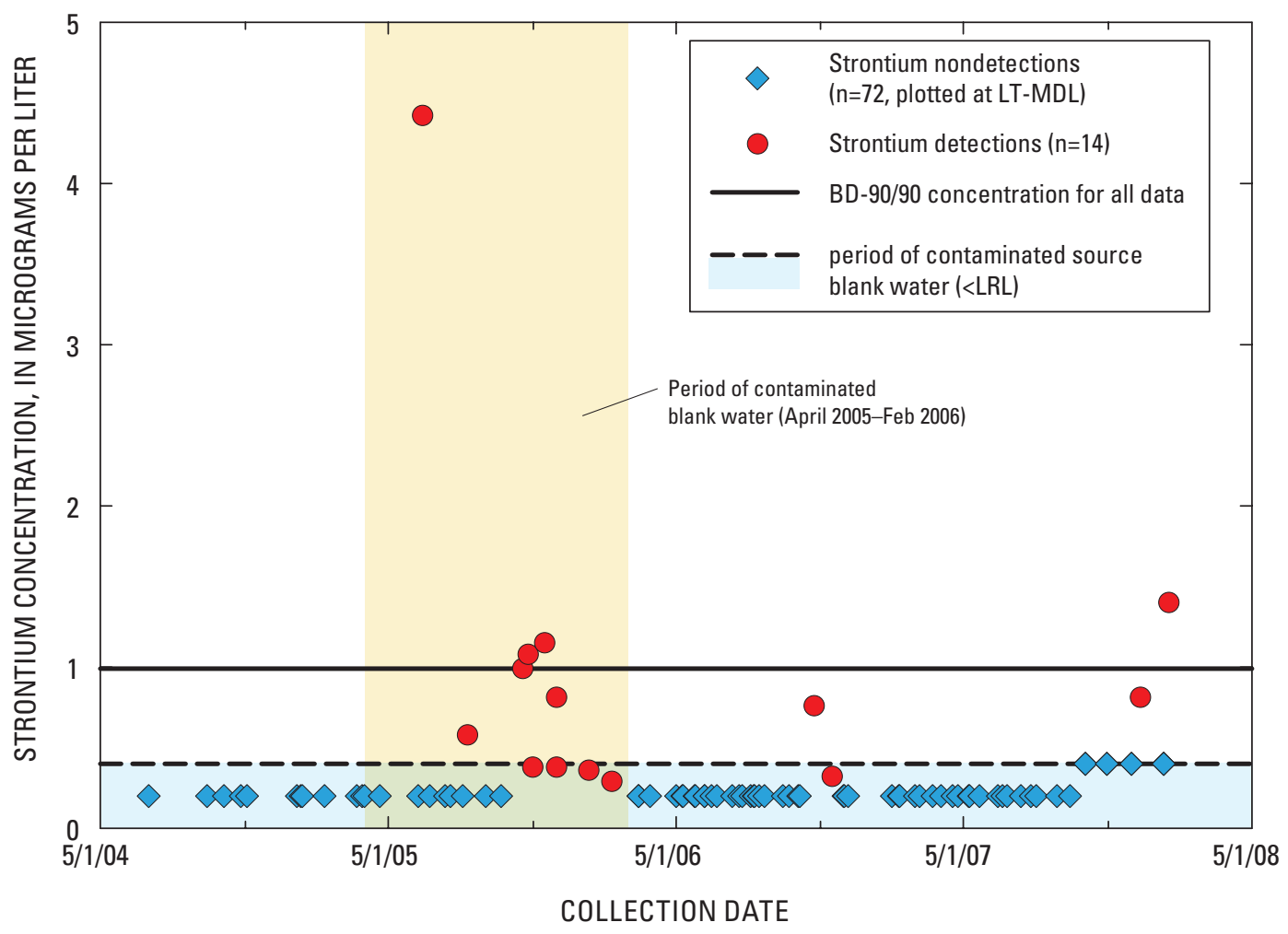

Figure 14. Strontium (Sr) concentrations in field blanks collected from May 2004 through January 2008, plotted in time-series with the BD-90/90 concentration (nondetections plotted at their LT-MDLs). BD-90/90, 90th percentile concentration determined using binomial distribution with a confidence level that is 90 percent or greater; LT-MDL, long-term method detection level; $n$, number of samples. 


\section{Tungsten (W)}

8 of 85 field blanks ( 9 percent) collected for tungsten had detections (fig. 15, table 2). These detections ranged in concentration from E0.03 to $0.38 \mu \mathrm{g} / \mathrm{L}$. The BD-90/90 concentration calculated for tungsten was $0.11 \mu \mathrm{g} / \mathrm{L}$, which was between two LRLs used throughout the study period ( 0.06 and $0.5 \mu \mathrm{g} / \mathrm{L}$ ). Tungsten was not detected in any of the 14 sourcesolution blanks collected for this constituent. Tungsten was rarely analyzed by the NWQL for the certification of blank water; however, when it was analyzed, it was not detected above the LT-MDL (appendix table A1). Tungsten did not have any systematic laboratory contamination above the LRL based on the BQS Blind Blank Project data (BQS BD-90/90 of $0.009 \mu \mathrm{g} / \mathrm{L}$, table 3).
An SRL of $0.11 \mu \mathrm{g} / \mathrm{L}$ was established (table 2), based on the BD-90/90 value calculated from the field blanks, as a safeguard against low-level tungsten contamination, regardless of the unknown potential source(s). Analytical results less than $0.11 \mu \mathrm{g} / \mathrm{L}$ should be remarked as less than or equal to $(\leq)$ the reported value.

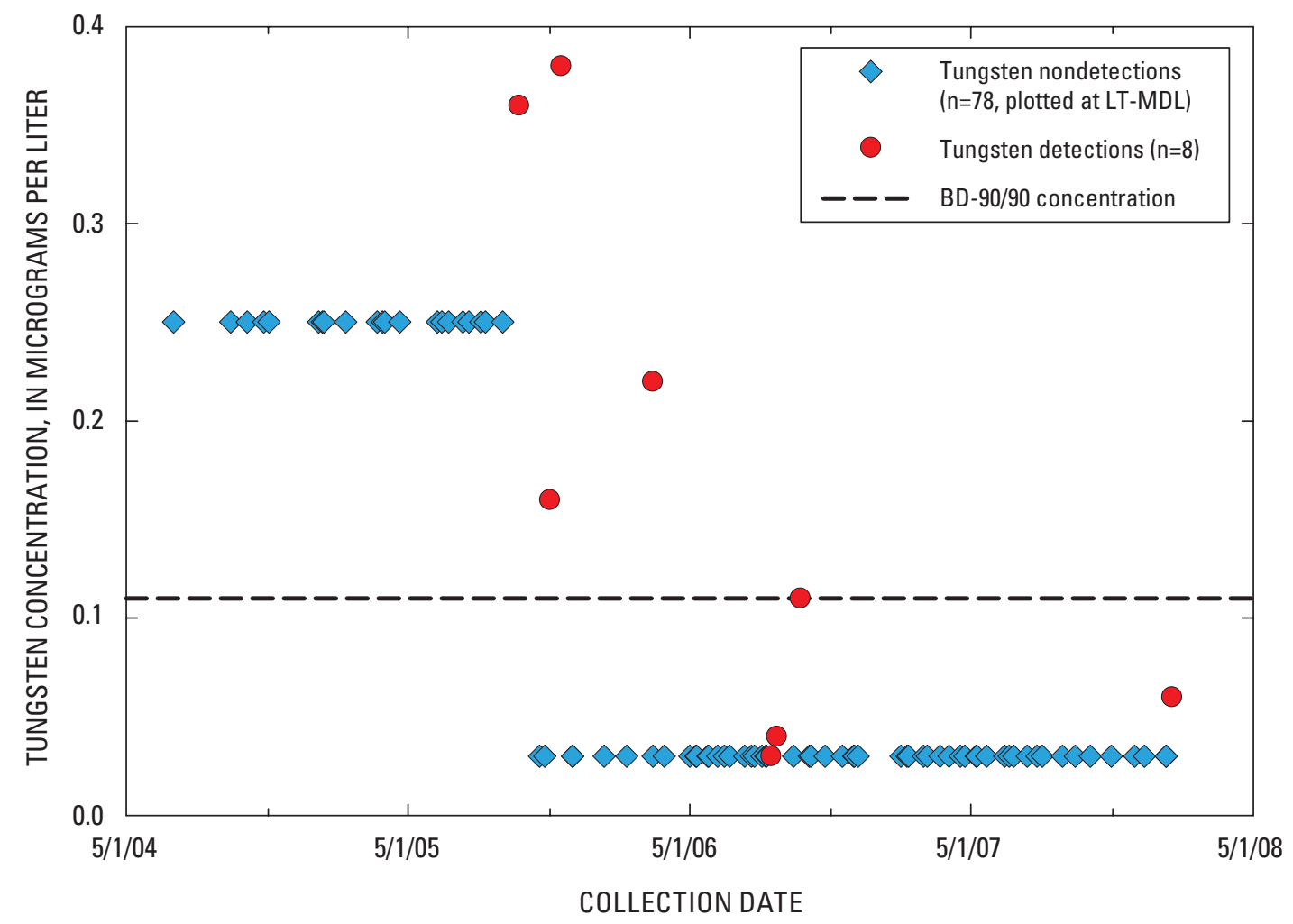

Figure 15. Tungsten (W) concentrations in field blanks collected from May 2004 through January 2008, plotted in time-series with the BD-90/90 concentration (nondetections plotted at their LT-MDLs). BD-90/90, 90th percentile concentration determined using binomial distribution with a confidence level that is 90 percent or greater; LT-MDL, long-term method detection level; n, number of samples. 


\section{Vanadium (V)}

Nine of 86 field blanks ( 8 percent) collected for vanadium had detections (fig. 16, table 2). These detections ranged in concentration from E0.02 to $0.8 \mu \mathrm{g} / \mathrm{L}$. The BD-90/90 concentration calculated for vanadium was $0.10 \mu \mathrm{g} / \mathrm{L}$, equal to the highest LRL used throughout the study period.

Vanadium was not detected in any of the 15 sourcesolution blanks collected during the study period. Vanadium was not detected above the LRL in analyses of blank water performed by the NWQL for certification purposes (appendix table A1). Vanadium did not have any systematic laboratory contamination above the LRL according to a review of the BSQ Blind Blank Project data (BQS BD-90/90 of $0.02 \mu \mathrm{g} / \mathrm{L}$, table 3). Thus, the source of sporadic low-level vanadium contamination bias of field blanks, and potentially of the groundwater samples, is unknown. An SRL of $0.10 \mu \mathrm{g} / \mathrm{L}$ (table 2) was established based on the BD-90/90 concentration calculated from the field-blank data. This SRL is far below the NL-CA of $50 \mu \mathrm{g} / \mathrm{L}$. Analytical results less than $0.10 \mu \mathrm{g} / \mathrm{L}$ should be remarked as less than or equal to $(\leq)$ the reported value.

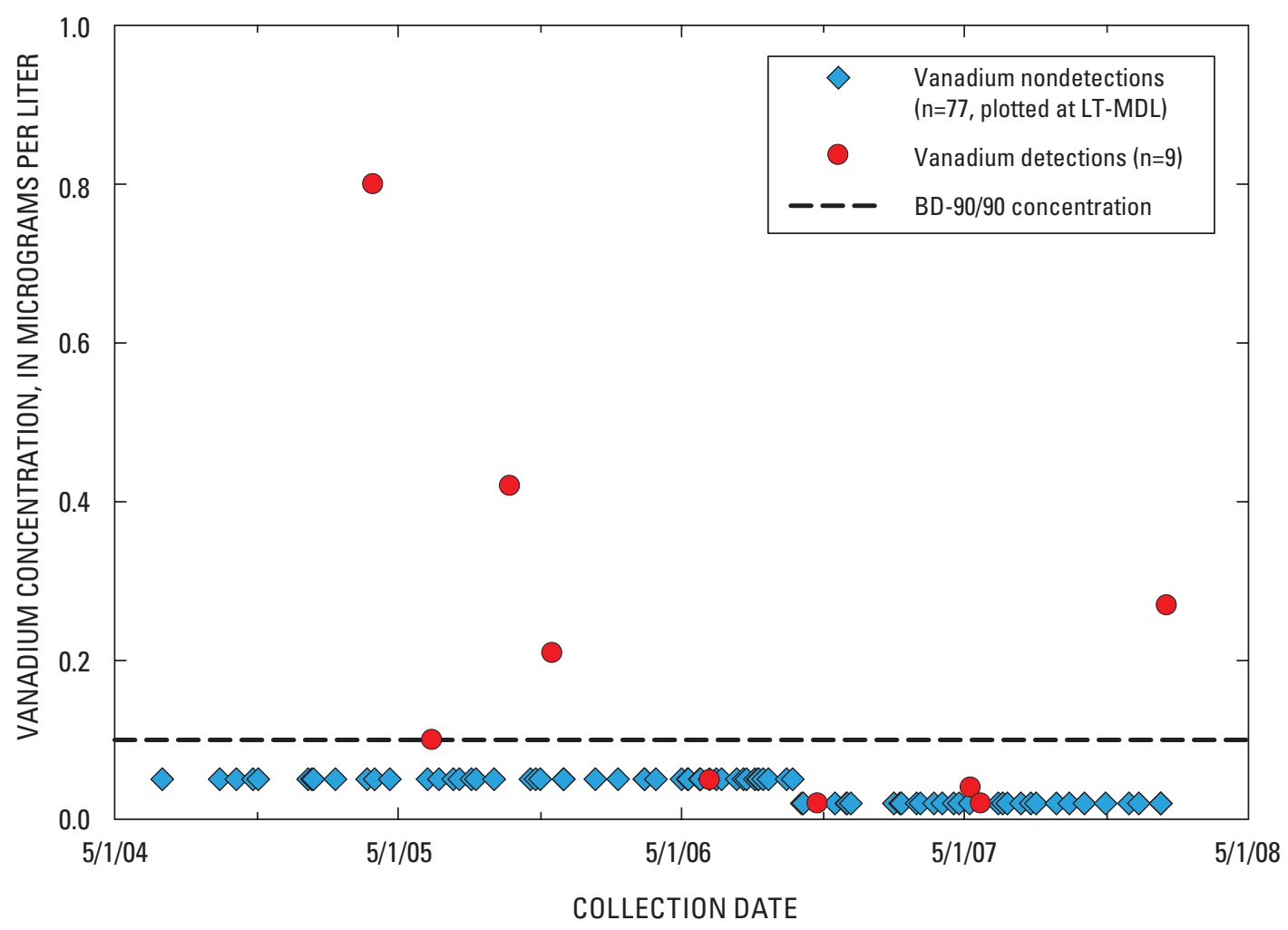

Figure 16. Vanadium (V) concentrations in field blanks collected from May 2004 through January 2008, plotted in time-series with the BD-90/90 concentration (nondetections plotted at their LT-MDLs). BD-90/90, 90th percentile concentration determined using binomial distribution with a confidence level that is 90 percent or greater; LT-MDL, long-term method detection level; $n$, number of samples. 


\section{Zinc $(\mathrm{Zn})$}

Thirty-two of 86 field blanks (37 percent) collected for zinc had detections (fig. 17, table 2). These detections ranged in concentration from E0.3 to $8.7 \mu \mathrm{g} / \mathrm{L}$. The BD-90/90 concentration calculated for zinc was $4.8 \mu \mathrm{g} / \mathrm{L}$, which is above the LRLs of 0.6 and $1.8 \mu \mathrm{g} / \mathrm{L}$ that were used throughout the study period. The time-series plot for zinc shows frequent, but sporadic, contamination lasting until early May 2007. The potential for laboratory contamination by zinc was considered by evaluating the BQS Blind Blank Project data (table 3). Concentrations up to $1.09 \mu \mathrm{g} / \mathrm{L}$ were measured (http://bqs. usgs.gov/bbp/BBPICPMS Fil.html); however, this does not explain the prevalence or magnitude of zinc measured in the field blanks collected for the GAMA Program.
Zinc was not detected in any of the 15 source-solution blanks collected. Zinc was detected above the LT-MDL in some lots of blank water tested by the NWQL, including samples of NWIS-I Lot No. 80402 analyzed in February 2005 $(0.803 \mu \mathrm{g} / \mathrm{L})$ and May/June $2005(0.641 \mu \mathrm{g} / \mathrm{L})$, NWIS-I Lot No. 80502 analyzed in March 2005 (Bottle \#4: $0.997 \mu \mathrm{g} / \mathrm{L}$ ), and NWIS-I Lot No. 80703 analyzed in September 2007 (Bottle \#1: $0.301 \mu \mathrm{g} / \mathrm{L}$; Bottle \#4: $0.595 \mu \mathrm{g} / \mathrm{L}$ ) (appendix table A1). However, even the highest of these concentrations did not explain the BD-90/90 concentration of $4.8 \mu \mathrm{g} / \mathrm{L}$; therefore, field sources of contamination also had to be considered.

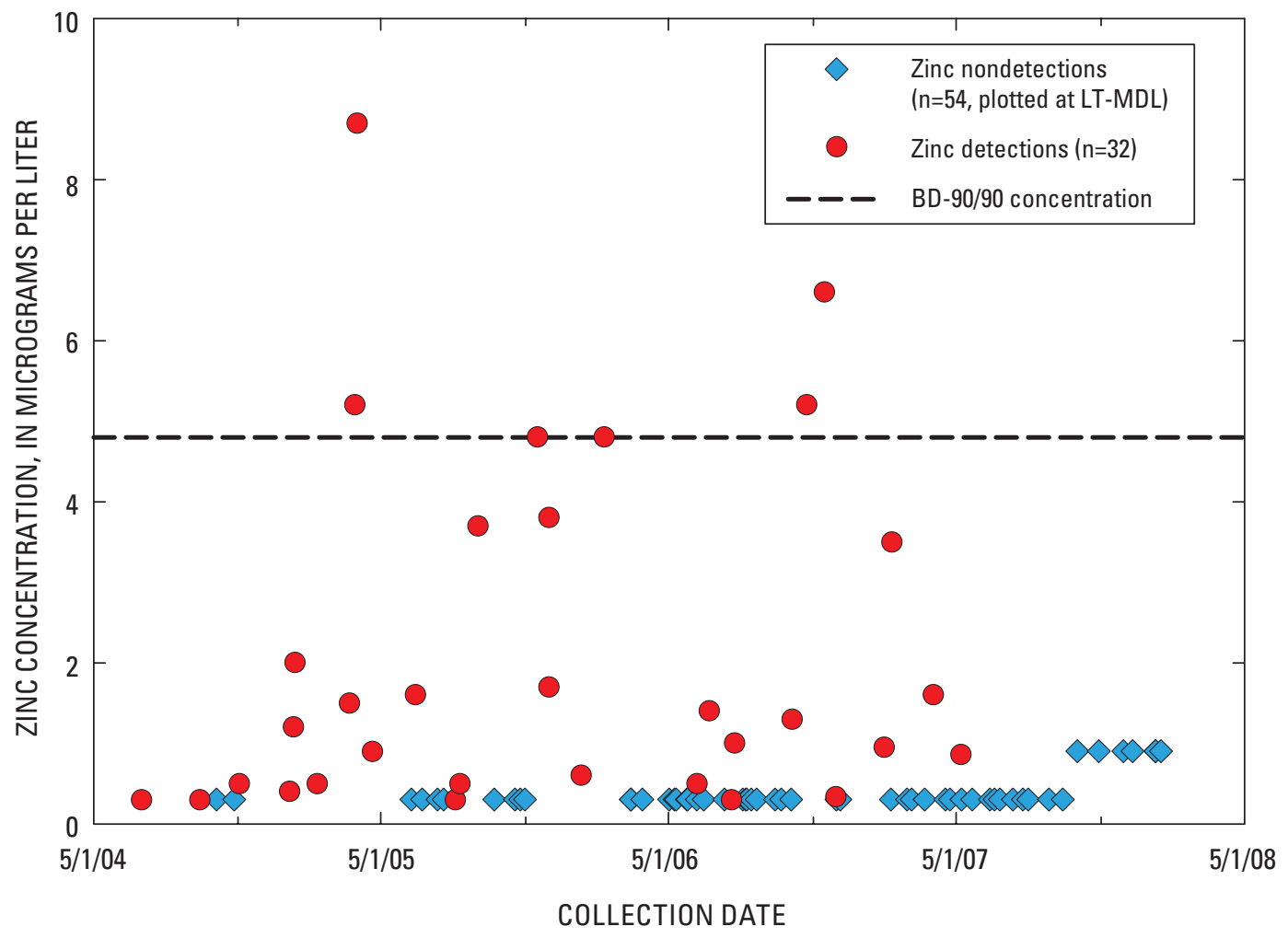

Figure 17. Zinc $(\mathrm{Zn})$ concentrations in field blanks collected from May 2004 through January 2008, plotted in time-series with the BD-90/90 concentration (nondetections plotted at their LT-MDLs). BD-90/90, 90th percentile concentration determined using binomial distribution with a confidence level that is 90 percent or greater; LT-MDL, long-term method detection level; SRL, study reporting level; SMCL-CA, secondary maximum contaminant level-California. 
Zinc is a major component of brass, which is in many of the metal fittings and equipment used for sampling. Standard USGS procedures for cleaning the sampling equipment and connections are expected to mitigate this potential source of contamination. The possible mixtures of zinc contamination from laboratory sources, certain lots of blank water, and field sources cannot be fully determined using the existing QC data. Therefore, an SRL was established at the BD-90/90 concentration of $4.8 \mu \mathrm{g} / \mathrm{L}$ (table 2 ). This SRL is substantially below the SMCL-CA of $5,000 \mu \mathrm{g} / \mathrm{L}$. Analytical results less than $4.8 \mu \mathrm{g} / \mathrm{L}$ should be remarked as less than or equal to $(\leq)$ the reported value.
The implications of the SRL for zinc, $4.8 \mu \mathrm{g} / \mathrm{L}$, for reporting environmental sample data was explored by plotting the groundwater sample data with the field-blank data and SRL (fig. 18). Although most of the groundwater concentration data are below $4.8 \mu \mathrm{g} / \mathrm{L}$, the distribution of the field-blank data clearly indicates that zinc results below the SRL could have an unacceptably high rate of false positives.
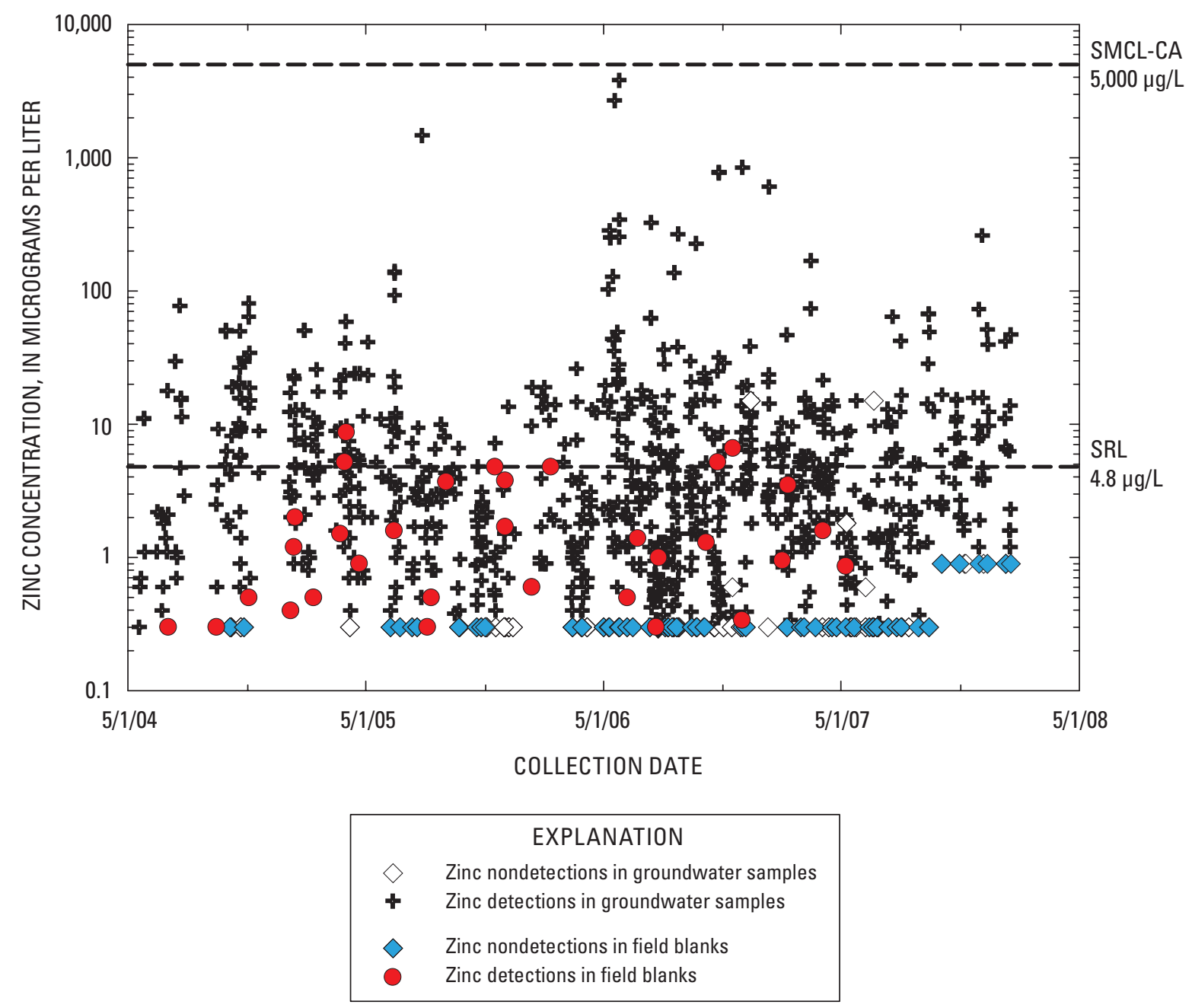

Figure 18. Zinc $(\mathrm{Zn})$ concentrations in groundwater samples and field blanks collected from May 2004 through January 2008, plotted in time-series with the SRL and SMCL-CA. 


\section{Summary}

Groundwater quality was investigated in samples collected from May 2004 through January 2008 as part of the Priority Basins Project of the Groundwater Ambient Monitoring and Assessment (GAMA) Program. The project is a comprehensive assessment of statewide groundwater quality designed to identify and characterize risks to groundwater resources and to increase the availability of information about groundwater quality to the public.

Trace-element field blanks were collected as part of the quality-control process for this project and were reviewed to determine potential bias to the corresponding environmental sample results. Bias in the environmental data could be related to contamination in the field from contact between groundwater and sampling equipment or other contaminant sources, or to contamination during processing, shipping, or analyzing the samples. Bias can affect the interpretation of results, particularly if any constituents are present in the samples solely as a result of extrinsic contamination that would otherwise be absent from the groundwater that was sampled, or if concentrations in environmental samples are artificially elevated so that they falsely appear to be above a regulatory limit. Data from source-solution blanks and blind laboratory qualitycontrol samples also were considered in evaluating potential contamination bias, and these data proved useful in limiting the scope of the effects of certain contaminant sources on the groundwater samples.

Twenty-five different trace elements were analyzed for 86 field blanks collected from May 2004 to January 2008; these were aluminum (Al), antimony ( $\mathrm{Sb})$, arsenic (As), barium $(\mathrm{Ba})$, beryllium $(\mathrm{Be})$, boron $(\mathrm{B})$, cadmium $(\mathrm{Cd})$, chromium $(\mathrm{Cr})$, cobalt $(\mathrm{Co})$, copper $(\mathrm{Cu})$, iron $(\mathrm{Fe})$, lead $(\mathrm{Pb})$, lithium (Li), manganese (Mn), mercury (Hg), molybdenum (Mo), nickel (Ni), selenium (Se), silver ( $\mathrm{Ag})$, strontium ( $\mathrm{Sr})$, thallium (Tl), tungsten (W), uranium (U), vanadium (V), and zinc $(\mathrm{Zn})$. Results from these field blanks can aid in data interpretation for the 816 groundwater samples collected during the same period. The field-blank data were used to determine the detection frequency and to estimate the upper limit of the $90^{\text {th }}$ percentile concentration with at least 90 percent confidence for each trace element. These results were compared with each constituent's laboratory method detection limit (LT-MDL) to determine whether a raised study reporting level (SRL) was necessary to ensure that no more than 10 percent of the measured concentration in any groundwater sample could be attributed to contamination bias.

Twelve trace elements were detected in fewer than 5 percent of the field blanks, and thus establishing SRLs for these trace elements was not necessary; these elements were $\mathrm{Sb}, \mathrm{As}, \mathrm{Be}, \mathrm{B}, \mathrm{Cd}, \mathrm{Co}, \mathrm{Li}, \mathrm{Mo}, \mathrm{Se}, \mathrm{Ag}, \mathrm{Tl}$, and U.
Thirteen constituents were detected in more than 5 percent of the blanks. Six of the thirteen (Al, Ba, Cr, Hg, Mn, and V) required SRLs that were at or below the highest laboratory reporting levels (LRL) used during the sampling period; these SRLs were applicable to values reported between the LT-MDL and LRL. The remaining seven constituents that were detected in more than 5 percent of the blanks had concentrations in field blanks that necessitated SRLs that were above the highest LRLs used during the study period. SRLs for these constituents, usually set at the $90^{\text {th }}$ percentiles of their concentrations in the field blanks, were below the regulatory thresholds established for drinking water. The recommendation to report measured concentrations below the SRLs as less than or equal to $(\leq)$ the reported value would not affect identification of values above the thresholds. These seven constituents (SRLs and drinking-water thresholds, respectively, in micrograms per liter $[\mu \mathrm{g} / \mathrm{L}])$ were $\mathrm{Cu}(1.7$ and $1,300 \mu \mathrm{g} / \mathrm{L}), \mathrm{Fe}(6$ and $300 \mu \mathrm{g} / \mathrm{L}), \mathrm{Pb}(0.65$ and $15 \mu \mathrm{g} / \mathrm{L}), \mathrm{Ni}(0.36$ and $100 \mu \mathrm{g} / \mathrm{L}), \mathrm{Sr}$ $(0.99$ and $4,000 \mu \mathrm{g} / \mathrm{L}), \mathrm{W}(0.11 \mu \mathrm{g} / \mathrm{L}$ and no threshold $)$, and $\mathrm{Zn}(4.8$ and $5,000 \mu \mathrm{g} / \mathrm{L})$.

Contaminant sources considered in this review of the trace-element field-blank data include specific lots of blank water used for the field blanks, which were shown to have little or no effect on the groundwater samples and thus did not affect the SRLs. Low-level laboratory contamination was identified for a few trace elements, but was usually within the $90^{\text {th }}$ percentiles of the field-blank data and thus was not a large factor in determining the need for or the magnitude of the SRLs. In addition, for some trace elements (particularly iron, mercury, and zinc), contact with sample bottles or metal components in the sampling equipment did appear to affect the field blanks and groundwater samples similarly, and these biases were reflected in the SRLs for these constituents. The SRLs can be used to minimize the risk of reporting false positives for trace elements for the groundwater samples collected for this study.

\section{Acknowledgments}

The authors thank the following cooperators for their support: the State Water Resources Control Board (SWRCB), the California Department of Public Health, the California Department of Water Resources, and Lawrence Livermore National Laboratory. We especially thank the participating well owners for their generosity in allowing the USGS to collect groundwater samples from their wells. Technical reviewers, David K. Mueller and Barbara Dawson of the USGS, provided valuable comments to improve this work. Funding for this work was provided by State bonds authorized by Proposition 50 and administered by the SWRCB. 


\section{References Cited}

Belitz, Kenneth, Dubrovsky, N.M., Burow, K.R., Jurgens, B.C., and Johnson, T., 2003, Framework for a ground-water quality monitoring and assessment program for California: U.S. Geological Survey Water-Resources Investigations Report 03-4166, 78 p. Available at http://pubs.usgs.gov/wri/ wri034166/

Bennett, G.L., V, Belitz, Kenneth, and Milby Dawson, B.J., 2006, California GAMA Program - Ground-water quality data in the northern San Joaquin basin study unit, 2005: U.S. Geological Survey Data Series 196, 122 p. Available at http://pubs.usgs.gov/ds/2006/196/

Bennett, P.A., Bennett, G.L., V, and Belitz, Kenneth, 2009, Groundwater-quality data in the northern Sacramento Valley, 2007: Results from the California GAMA program: U.S. Geological Survey Data Series 452, 90 p. Available at http://pubs.usgs.gov/ds/452/

Burton, C.A., and Belitz, Kenneth, 2008, Ground-water quality data in the southeast San Joaquin Valley, 2005-2006Results from the California GAMA Program: U.S. Geological Survey Data Series 351, 103 p. Available at $h t t p: / / p u b s$. usgs.gov/ds/351/

California Department of Public Health, 2007, California Code of Regulations. Title 22, Division 4 Environmental Health, chap. 15, Domestic Water Quality and Monitoring Regulations: Register 2007, no. 4 accessed February 10, 2007, at http://ccr.oal.ca.gov/

California State Water Resources Control Board, 2003, A comprehensive groundwater quality monitoring program for California: Assembly Bill 599 Report to the Governor and Legislature, March 2003, 100 p. Available at http:// www.waterboards.ca.gov/gama/docs/final_ab_599_rpt_to_ legis_7_31_03.pdf

Childress, C.J.O., Foreman, W.T., Connor, B.F., and Maloney, T.J., 1999, New reporting procedures based on longterm method detection levels and some considerations for interpretations of water-quality data provided by the U.S. Geological Survey National Water Quality Laboratory: U.S. Geological Survey Open-File Report 99-193, 19 p.

Dawson, B.J., Bennett, G.L., V, and Belitz, Kenneth, 2008, Ground-water quality data in the southern Sacramento Valley, California, 2005-Results from the California GAMA Program: U.S. Geological Survey Data Series 285, 93 p. Available at http://pubs.usgs.gov/ds/285/

Densmore, J.N., Fram, M.S., and Belitz, Kenneth, 2009, Ground-water quality data in the Owens and Indian Wells Valleys study unit, 2006: Results from the California GAMA program: U.S. Geological Survey Data Series 427, 86 p. Available at $h t t p: / / p u b s . u s g s . g o v / d s / 427 /$
Ferrari, M.J., Fram, M.S., and Belitz, Kenneth, 2008, Groundwater quality in the central Sierra study unit, California, 2006: Results from the California GAMA program: U.S. Geological Survey Data Series 335, 60 p. Available at http:// pubs.usgs.gov/ds/335/

Fishman, M.J., 1993, ed., Methods of analysis by the U.S. Geological Survey National Water Quality Laboratory determination of inorganic and organic constituents in water and fluvial sediments: U.S. Geological Survey Open-File Report 93-125, $217 \mathrm{p}$.

Fram, M.S., and Belitz, Kenneth, 2007, Ground-water quality data in the Southern Sierra Study Unit, 2006-Results from the California GAMA Program: U.S. Geological Survey Data Series 301, 78 p. Available at http://pubs.usgs.gov/ $d s / 301 /$

Fram, M.S., Munday, Cathy, and Belitz, Kenneth, 2009, Groundwater quality data for the Tahoe-Martis study unit, 2007: Results from the California GAMA Program: U.S. Geological survey Data Series 432, 88 p. Available at $h t t p: / /$ pubs.usgs.gov/ds/432/

Garbarino, J.R., 1999, Methods of analysis by the U.S. Geological Survey National Water Quality LaboratoryDetermination of dissolved arsenic, boron, lithium, selenium, strontium, thallium, and vanadium using inductively coupled plasma-mass spectrometry: U.S. Geological Survey Open-File Report 99-093, 31 p.

Garbarino, J.R., and Damrau, D.L., 2001, Methods of analysis by the U.S. Geological Survey National Water Quality Laboratory-Determination of organic plus inorganic mercury in filtered and unfiltered natural water with cold vaporatomic fluorescence spectrometry: U.S. Geological Survey Water-Resources Investigations Report 01-4132, 16 p.

Garbarino, J.R., Kanagy, L.K., and Cree, M.E., 2006, Determination of elements in natural-water, biota, sediment, and soil samples using collision/reaction cell inductively coupled plasma-mass spectrometry: U.S. Geological Survey Techniques and Methods, book 5, chap. B1, 88 p.

Goldrath, D.A., Wright, M.T., and Belitz, Kenneth, 2009, Ground-water quality data in the Coachella Valley study unit, 2007: Results from the California GAMA Program: U.S. Geological Survey Data Series 373, 70 p. Available at http://pubs.usgs.gov/ds/373/

Hahn, G.J., and Meeker, W.Q., 1991, Statistical intervals-A guide to practitioners: New York, John Wiley and Sons, $392 \mathrm{p}$.

Helsel, D.R., 2005, Nondetects and data analysis: Statistics for censored environmental data: New York, John Wiley and Sons, $268 \mathrm{p}$. 
Helsel, D.R., and Hirsch, R.M., 2002, Statistical methods in water resources: U.S. Geological Survey Techniques of Water-Resources Investigations, book 4, chap. A3, 510 p. Available at http://pubs.usgs.gov/twri/twri4a3/

Hutson, S.S., Barber, N.L., Kenny, J.F., Linsey, K.S., Lumia, D.S., and Maupin, M.A., 2004, Estimated use of water in the United States in 2000: U.S. Geological Survey Circular 1268,46 p.

Kent, Robert, and Belitz, Kenneth, 2009, Ground-water quality data in the Upper Santa Ana Watershed Study Unit, November 2006 to March 2007: Results from the California GAMA Program: U.S. Geological Survey Data Series 404, 116 p. Available at http://pubs.usgs.gov/ds/404/

Koterba, M.T., Wilde, F.D., and Lapham, W.W., 1995, Ground-water data-collection protocols and procedures for the National Water-Quality Assessment Program: Collection and documentation of water-quality samples and related data: U.S. Geological Survey Open-File Report 95-399, 113 p. Available at http://pubs.usgs.gov/of/1995/ofr-95-399/pdf/ of95-399.pdf

Kulongoski, J.T., and Belitz, Kenneth, 2007, Ground-water quality data in the Monterey Bay and Salinas Valley Basins, California, 2005-Results from the California GAMA Program: U.S. Geological Survey Data Series 258. Available at http://pubs.usgs.gov/ds/2007/258/

Kulongoski, J.T., Belitz, Kenneth, and Dawson, B.J., 2006, Ground-water quality data in the North San Francisco Bay hydrologic provinces, California, 2004: Results from the California Ground-Water Ambient Monitoring and Assessment (GAMA) Program: U.S. Geological Survey Data Series Report 167, 100 p. Available at http://pubs.usgs.gov/ $d s / d s 167 /$

Land, Michael, and Belitz, Kenneth, 2008, Ground-water quality data in the San Fernando-San Gabriel study unit, 2005-Results from the California GAMA Program: U.S. Geological Survey Data Series 356, 84 p. Available at http:// pubs.usgs.gov/ds/356/

Landon, M.K., and Belitz, Kenneth, 2008, Ground-water quality data in the Central Eastside San Joaquin Basin 2006: Results from the California GAMA Program: U.S. Geological Survey Data Series 325, 88 p. Available at http://pubs. usgs.gov/ds/325/

Lane, S.L., Flanagan, Sarah, and Wilde, F.D., 2003, Selection of equipment for water sampling (ver. 2.0): U.S. Geological Survey Techniques of Water-Resources Investigations, book 9, chap. A2, accessed June 16, 2008 at http://pubs.water. usgs.gov/twri9A2/

Ludtke, A.S., and Woodworth, M.T., 1997, USGS blind sample project - monitoring and evaluating laboratory analytical quality: U.S. Geological Survey Fact-Sheet 97-136, 1 p.
Maloney, T.J., ed., 2005, Quality management system, U.S. Geological Survey National Water Quality Laboratory: U.S. Geological Survey Open-File Report 2005-1263. Available at http://pubs.usgs.gov/of/2005/1263/pdf/OFR2005-1263. $p d f$

Mathany, T.M., and Belitz, Kenneth, 2009, Groundwater-quality data in the Mojave study unit, 2008: Results from the California GAMA Program: U.S. Geological Survey Data Series 440, 80 p. Available at http://pubs.usgs.gov/ds/440/

Mathany, T.M., Kulongski, J.T., Ray, M.C., and Belitz, Kenneth, 2009, Groundwater quality data in the South Coast Interior Basins study unit, 2008: Results from the California GAMA program: U.S. Geological Survey Data Series 463, 82 p. Available at http://pubs.usgs.gov/ds/463/

Mathany, T.M., Land, Michael, and Belitz, Kenneth, 2008, Ground-water quality data in the coastal Los Angeles Basin study unit, 2006: Results from the California GAMA Program: U.S. Geological Survey Data Series 387, Version 1.1, 98 p. Available at http://pubs.usgs.gov/ds/387

Montrella, Joseph, and Belitz, Kenneth, 2009, Ground-water quality data in the Santa Clara River Valley study unit, 2007: Results from the California GAMA Program: U.S. Geological Survey Data Series 408, 84 p. Available at $h t t p: / /$ pubs.usgs.gov/ds/408/

Pirkey, K.D., and Glodt, S.R., 1998, Quality control at the U.S. Geological Survey National Water Quality Laboratory: U.S. Geological Survey Fact Sheet 026-98, 4 p. Available at http://ny.water.usgs.gov/pubs/fs/fs02698/FS026-98.pdf

Ray, M.C., Kulongoski, J.T., and Belitz, Kenneth, 2009, Ground-water quality data in the San Francisco Bay study unit, 2007: Results from the California GAMA program: U.S. Geological Survey Data Series 396, 92 p. Available at http://pubs.usgs.gov/ds/396/

Schmitt, S.J., Fram, M.S., Milby Dawson, B.J., Belitz, Kenneth, 2008, Ground-water quality data in the middle Sacramento Valley study unit, 2006-results from the California GAMA program: U.S. Geological Survey Data Series 385, 100 p. Available at http://pubs.usgs.gov/ds/385/

Shelton, J.L., Pimentel, Isabel, Fram, M.S., and Belitz, Kenneth, 2008, Ground-water quality data in the Kern County subbasin study unit, 2006-Results from the California GAMA Program: U.S. Geological Survey Data Series 337, 75 p. Available at http://pubs.usgs.gov/ds/337/

U.S. Environmental Protection Agency, 2002, Guidelines for establishing procedures for the analysis of pollutants: U.S. Code of Federal Regulations, Title 40, 136 p. 
U.S. Environmental Protection Agency, 2006, 2006 Edition of the drinking water standards and health advisories: U.S. Environmental Protection Agency, Office of Water EPA 822-R-06-013, 12 p., accessed June 16, 2008 at http://www. epa.gov/waterscience/criteria/drinking/dwstandards.pdf

U.S. Geological Survey, variously dated, National field manual for the collection of water-quality data: U.S. Geological Survey Techniques of Water-Resources Investigations, book 9, chap. A1-A9. Available at http://water.usgs.gov/owq/ FieldManual/

Wilde, F.D., ed., 2004, Cleaning of equipment for water sampling (ver. 2.0): U.S. Geological Survey Techniques of Water-Resources Investigations, book 9, chap. A3, accessed June 6, 2008 at http://pubs.water.usgs.gov/twri9A3/
Wilde, F.D., ed., 2006, Collection of water samples: U.S. Geological Survey Techniques of Water-Resources Investigations, book 9, chap. A4, accessed June 16, 2008 at http:// pubs.water.usgs.gov/twri9A4/

Wilde, F.D., Radtke, D.B., Gibs, J., and Iwatsubo, R.T., 2004, Processing of water samples: U.S. Geological Survey Techniques of Water-Resources Investigations, book 9, chap. A5, accessed June 16, 2008 at http://pubs.water.usgs.gov/ twri9A5/

Wright, M.T., Belitz, Kenneth, and Burton, C.A., 2005, California GAMA program: Ground-water quality in the San Diego drainages hydrologic province, California, 2004: U.S. Geological Survey Data Series 129, 91 p. Available at http://pubs.usgs.gov/ds/2005/129/ 


\section{Appendix}

Data for trace elements in blank-water certification samples analyzed by the U.S. Geological Survey (USGS) National Water Quality Laboratory from May 2004 through September 2007 for specified lots of universal blank water (UBW) and inorganic blank water (IBW) are given in the table. These data were compiled by Jim Lewis and his colleagues in the QualityAssurance Section of the NWQL. Raw data for these analyses are kept on file at the NWQL in Denver, Colorado. 
Appendix Table A1. Raw results of quality-control analyses for certification of universal blank water and inorganic blank water provided by the U.S. Geological Survey National Water Quality Laboratory and used by the Groundwater Ambient Monitoring and Assessment (GAMA) program from May 2004 through January 2008.

[National Water Quality Laboratory certification analyses of blank water are reported as raw results without rounding or censoring; analytical variability and calibration techniques can cause results to be negative or below long-term method detection levels (LT-MDLs). NWIS-I lot numbers are used for tracking. Abbreviations: $\mu \mathrm{g} / \mathrm{L}$, microgram per liter; emd, universal blank water from EMD Chemicals, Inc.; NWIS, National Water Information System; rcc, inorganic blank water from Ricca Chemical Company; *, value between the LT-MDL and laboratory reporting level (LRL); ${ }^{* *}$, value above the LRL]

\begin{tabular}{|c|c|c|c|c|c|c|c|c|c|}
\hline $\begin{array}{l}\text { NWIS-I } \\
\text { lot number }\end{array}$ & $\begin{array}{c}\text { Vendor lot } \\
\text { number }\end{array}$ & $\begin{array}{c}\text { Period of } \\
\text { availability }\end{array}$ & $\begin{array}{c}\text { Analysis } \\
\text { date }\end{array}$ & $\begin{array}{c}\text { Aluminum } \\
(\mu \mathrm{g} / \mathrm{L})\end{array}$ & $\begin{array}{c}\text { Antimony } \\
\text { ( } \mu \mathrm{g} / \mathrm{L})\end{array}$ & $\begin{array}{c}\text { Arsenic } \\
\text { ( } \mu \mathrm{g} / \mathrm{L})\end{array}$ & $\begin{array}{c}\text { Barium } \\
\text { ( } \mu \mathrm{g} / \mathrm{L})\end{array}$ & $\begin{array}{c}\text { Beryllium } \\
\text { ( } \mu \mathrm{g} / \mathrm{L})\end{array}$ & $\begin{array}{l}\text { Boron } \\
(\mu \mathrm{g} / \mathrm{L})\end{array}$ \\
\hline \multirow[t]{2}{*}{80301} & emd 43084 & $05 / 31 / 2003-03 / 31 / 2005$ & $05 / 2003$ & 0.797 & 0.003 & 0.004 & 0.012 & -0.001 & -0.005 \\
\hline & & & $02 / 2004$ & 0.005 & 0.006 & 0.020 & 0.007 & 0.000 & -0.051 \\
\hline 80401 & emd 44048 & 06/30/2004-06/30/2005 & $06 / 2004$ & -0.273 & -0.002 & -0.013 & 0.007 & 0.005 & -0.347 \\
\hline \multirow[t]{2}{*}{80402} & rcc 1406619 & 03/31/2005-06/30/2006 & $03 / 2005$ & 0.086 & 0.002 & -0.014 & 0.001 & -0.004 & -0.831 \\
\hline & & & $06 / 2005$ & 0.120 & 0.020 & -0.003 & 0.016 & 0.010 & * 5.214 \\
\hline \multirow{5}{*}{80501} & & through $02 / 28 / 2006$ ) & $04 / 2006$ & $* * 74.469$ & 0.012 & 0.010 & $* * 0.927$ & 0.016 & -0.332 \\
\hline & & & $04 / 2006$ & $* * 44.207$ & 0.007 & -0.010 & $* * 0.379$ & 0.022 & -0.737 \\
\hline & & & $04 / 2006$ & ** 13.332 & 0.005 & -0.010 & 0.072 & 0.027 & -0.411 \\
\hline & & & $04 / 2006$ & $* * 14.481$ & 0.004 & 0.000 & 0.094 & 0.025 & -0.584 \\
\hline & & & $04 / 2006$ & $* * 9.952$ & 0.003 & -0.020 & 0.028 & 0.001 & -0.785 \\
\hline \multirow{8}{*}{80502} & & & $03 / 2005$ & 0.156 & -0.002 & 0.005 & 0.007 & 0.005 & -3.923 \\
\hline & & & $03 / 2005$ & 0.160 & -0.001 & -0.030 & 0.044 & -0.001 & 0.247 \\
\hline & & & $06 / 2005$ & 0.127 & -0.003 & -0.005 & 0.050 & -0.002 & -0.108 \\
\hline & & & $06 / 2005$ & 0.316 & 0.000 & 0.017 & 0.016 & -0.015 & -1.297 \\
\hline & & & $06 / 2005$ & 0.163 & 0.018 & -0.003 & * 0.148 & -0.003 & 1.945 \\
\hline & & & $06 / 2005$ & 0.310 & 0.014 & 0.034 & 0.017 & -0.018 & -2.554 \\
\hline & & & $04 / 2006$ & 0.068 & 0.003 & -0.010 & 0.011 & 0.012 & 0.663 \\
\hline & & & $04 / 2006$ & 0.056 & 0.001 & -0.010 & 0.009 & 0.006 & 0.005 \\
\hline \multirow[t]{2}{*}{80602} & rec 1604792 & 06/30/2006-06/30/2007 & $06 / 2006$ & 0.118 & -0.026 & 0.010 & 0.004 & 0.007 & -1.262 \\
\hline & & & $06 / 2006$ & 0.183 & -0.001 & -0.030 & 0.003 & 0.000 & -0.269 \\
\hline 80605 & & & $10 / 2007$ & $* * 4.841$ & 0.003 & 0.011 & 0.010 & 0.003 & -0.508 \\
\hline \multirow[t]{2}{*}{80701} & rec 1701814 & 02/28/2007-02/29/2008 & $02 / 2007$ & 0.070 & 0.010 & 0.000 & 0.030 & 0.000 & 0.091 \\
\hline & & & $10 / 2007$ & 0.363 & 0.003 & 0.016 & 0.010 & 0.005 & -0.553 \\
\hline \multirow[t]{4}{*}{80703} & rcc 1709365 & 09/30/2007-09/30/2008 & $09 / 2007$ & 0.042 & 0.001 & 0.008 & 0.011 & 0.000 & $* * 21.49$ \\
\hline & & (GAMA only used it & $09 / 2007$ & 0.064 & 0.001 & 0.006 & 0.003 & -0.001 & $* * 21.54$ \\
\hline & & through 10/31/2007) & $09 / 2007$ & 0.077 & 0.001 & 0.004 & 0.000 & -0.001 & $* * 21.46$ \\
\hline & & & $09 / 2007$ & 0.114 & 0.001 & 0.005 & 0.007 & -0.001 & $* * 21.62$ \\
\hline \multirow[t]{4}{*}{80704} & $\operatorname{rcc} 4710088$ & $10 / 31 / 2007-10 / 31 / 2008$ & $10 / 2007$ & 0.000 & 0.085 & -0.003 & 0.004 & 0.002 & * 1.114 \\
\hline & & & $10 / 2007$ & 0.002 & 0.138 & 0.006 & 0.001 & 0.001 & * 0.997 \\
\hline & & & $10 / 2007$ & 0.002 & 0.247 & 0.003 & 0.009 & 0.001 & $* 1.259$ \\
\hline & & & $10 / 2007$ & 0.002 & 0.229 & 0.007 & 0.008 & 0.002 & * 1.073 \\
\hline
\end{tabular}


Appendix Table A1. Raw results of quality-control analyses for certification of universal blank water and inorganic blank water provided by the U.S. Geological Survey National Water Quality Laboratory and used by the Groundwater Ambient Monitoring and Assessment (GAMA) program from May 2004 through January 2008.—Continued

[National Water Quality Laboratory certification analyses of blank water are reported as raw results without rounding or censoring; analytical variability and calibration techniques can cause results to be negative or below long-term method detection levels (LT-MDLs). NWIS-I lot numbers are used for tracking. Abbreviations: $\mu \mathrm{g} / \mathrm{L}$, microgram per liter; emd, universal blank water from EMD Chemicals, Inc.; NWIS, National Water Information System; rcc, inorganic blank water from Ricca Chemical Company; *, value between the LT-MDL and laboratory reporting level (LRL); **, value above the LRL]

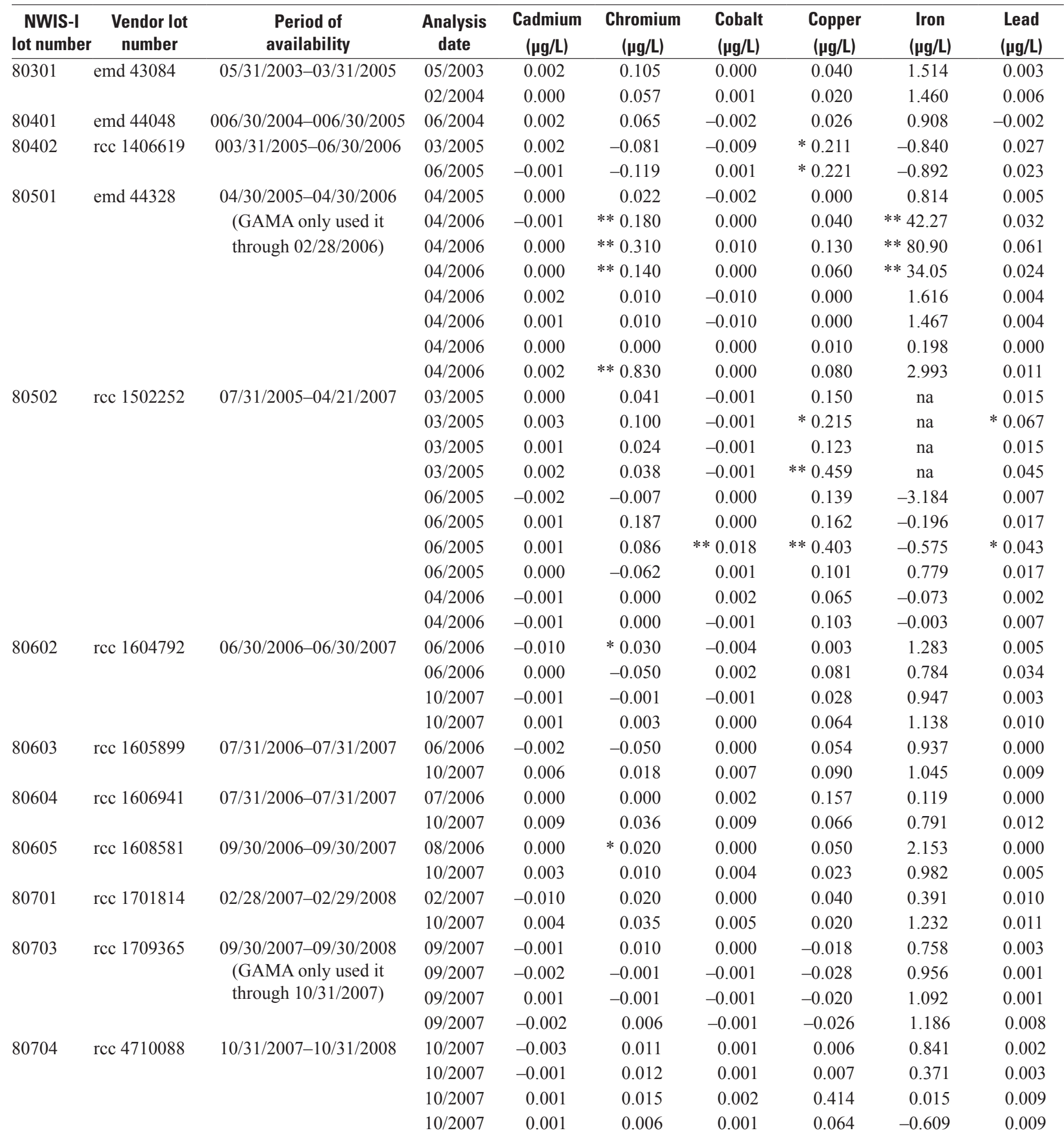


Appendix Table A1. Raw results of quality-control analyses for certification of universal blank water and inorganic blank water provided by the U.S. Geological Survey National Water Quality Laboratory and used by the Groundwater Ambient Monitoring and Assessment (GAMA) program from May 2004 through January 2008.—Continued

[National Water Quality Laboratory certification analyses of blank water are reported as raw results without rounding or censoring; analytical variability and calibration techniques can cause results to be negative or below long-term method detection levels (LT-MDLs). NWIS-I lot numbers are used for tracking. Abbreviations: $\mu \mathrm{g} / \mathrm{L}$, microgram per liter; emd, universal blank water from EMD Chemicals, Inc.; NWIS, National Water Information System; rcc, inorganic blank water from Ricca Chemical Company; *, value between the LT-MDL and laboratory reporting level (LRL); **, value above the LRL]

\begin{tabular}{|c|c|c|c|c|c|c|c|c|c|}
\hline $\begin{array}{l}\text { NWIS-I } \\
\text { Iot number }\end{array}$ & $\begin{array}{c}\text { Vendor lot } \\
\text { number }\end{array}$ & $\begin{array}{c}\text { Period of } \\
\text { availability }\end{array}$ & $\begin{array}{c}\text { Analysis } \\
\text { date }\end{array}$ & $\begin{array}{l}\text { Lithium } \\
\text { ( } \mu \mathrm{g} / \mathrm{L})\end{array}$ & $\begin{array}{c}\text { Manganese } \\
(\mu \mathrm{g} / \mathrm{L})\end{array}$ & $\begin{array}{c}\text { Mercury } \\
(\mu \mathrm{g} / \mathrm{L})\end{array}$ & $\begin{array}{c}\text { Molybde- } \\
\text { num } \\
(\mu \mathrm{g} / \mathrm{L})\end{array}$ & $\begin{array}{c}\text { Nickel } \\
(\mu \mathrm{g} / \mathrm{L})\end{array}$ & $\begin{array}{c}\text { Selenium } \\
(\mu \mathrm{g} / \mathrm{L})\end{array}$ \\
\hline 80301 & emd 43084 & $05 / 31 / 2003-03 / 31 / 2005$ & $05 / 2003$ & 0.007 & -0.006 & na & 0.003 & 0.010 & 0.069 \\
\hline 80401 & emd 44048 & $06 / 30 / 2004-06 / 30 / 2005$ & $06 / 2004$ & 0.005 & 0.008 & na & -0.014 & -0.014 & 0.027 \\
\hline 80402 & rcc 1406619 & $03 / 31 / 2005-06 / 30 / 2006$ & $03 / 2005$ & -0.006 & -0.037 & 0.000 & -0.002 & 0.025 & -0.090 \\
\hline \multirow{5}{*}{80501} & & (GAMA only used it & $04 / 2006$ & -0.026 & $* * 0.234$ & na & 0.014 & 0.010 & -0.110 \\
\hline & & through $02 / 28 / 2006$ ) & $04 / 2006$ & 0.034 & $* * 0.455$ & na & 0.018 & 0.020 & -0.090 \\
\hline & & & $04 / 2006$ & -0.011 & $* 0.159$ & na & 0.014 & 0.000 & -0.140 \\
\hline & & & $04 / 2006$ & -0.018 & 0.015 & na & 0.009 & 0.000 & -0.130 \\
\hline & & & $04 / 2006$ & -0.038 & 0.018 & na & 0.005 & 0.000 & -0.010 \\
\hline \multirow{9}{*}{80502} & & & $03 / 2005$ & -0.001 & -0.069 & na & -0.014 & 0.007 & 0.093 \\
\hline & & & $03 / 2005$ & -0.001 & -0.076 & na & -0.016 & -0.001 & 0.033 \\
\hline & & & $03 / 2005$ & -0.001 & -0.079 & na & -0.018 & $* 0.037$ & -0.048 \\
\hline & & & $06 / 2005$ & 0.011 & 0.015 & 0.001 & 0.002 & -0.004 & 0.046 \\
\hline & & & $06 / 2005$ & 0.038 & 0.055 & 0.000 & -0.001 & 0.029 & 0.108 \\
\hline & & & $06 / 2005$ & 0.000 & 0.061 & 0.000 & 0.019 & 0.002 & -0.019 \\
\hline & & & $06 / 2005$ & 0.000 & 0.034 & -0.002 & 0.011 & 0.008 & $* 0.246$ \\
\hline & & & $04 / 2006$ & 0.073 & 0.012 & na & 0.006 & 0.007 & -0.110 \\
\hline & & & $04 / 2006$ & 0.019 & 0.009 & na & 0.002 & -0.007 & -0.140 \\
\hline \multirow[t]{2}{*}{80602} & rcc 1604792 & $06 / 30 / 2006-06 / 30 / 2007$ & $06 / 2006$ & 0.002 & -0.100 & 0.000 & -0.007 & 0.008 & 0.010 \\
\hline & & & $06 / 2006$ & 0.151 & 0.039 & 0.002 & 0.003 & 0.012 & 0.010 \\
\hline \multirow[t]{2}{*}{80605} & rec 1608581 & 09/30/2006-09/30/2007 & $08 / 2006$ & -0.010 & 0.010 & 0.001 & 0.010 & $* * 0.060$ & 0.000 \\
\hline & & & $10 / 2007$ & -0.092 & 0.004 & -0.002 & 0.003 & 0.011 & -0.001 \\
\hline \multirow[t]{2}{*}{80701} & rec 1701814 & $02 / 28 / 2007-02 / 29 / 2008$ & $02 / 2007$ & -0.030 & -0.020 & 0.004 & $* * 0.120$ & 0.010 & 0.000 \\
\hline & & & $10 / 2007$ & -0.116 & 0.011 & -0.002 & 0.004 & 0.016 & -0.002 \\
\hline \multirow[t]{4}{*}{80703} & $\operatorname{rcc} 1709365$ & 09/30/2007-09/30/2008 & 09/2007 & 0.170 & 0.005 & 0.001 & 0.001 & -0.009 & -0.016 \\
\hline & & (GAMA only used it & $09 / 2007$ & 0.092 & 0.002 & -0.001 & 0.000 & -0.013 & -0.014 \\
\hline & & through 10/31/2007) & 09/2007 & 0.022 & 0.003 & 0.000 & -0.001 & -0.012 & -0.007 \\
\hline & & & 09/2007 & 0.054 & 0.025 & 0.000 & 0.000 & -0.011 & -0.031 \\
\hline \multirow[t]{4}{*}{80704} & $\operatorname{rcc} 4710088$ & $10 / 31 / 2007-10 / 31 / 2008$ & $10 / 2007$ & 0.282 & 0.023 & 0.001 & 0.001 & 0.024 & 0.002 \\
\hline & & & $10 / 2007$ & 0.285 & 0.023 & -0.002 & 0.001 & 0.008 & 0.006 \\
\hline & & & $10 / 2007$ & $* 0.570$ & 0.034 & 0.001 & 0.003 & 0.020 & 0.007 \\
\hline & & & $10 / 2007$ & $* 0.501$ & 0.010 & 0.000 & 0.003 & 0.006 & 0.001 \\
\hline
\end{tabular}


Appendix Table A1. Raw results of quality-control analyses for certification of universal blank water and inorganic blank water provided by the U.S. Geological Survey National Water Quality Laboratory and used by the Groundwater Ambient Monitoring and Assessment (GAMA) program from May 2004 through January 2008.—Continued

[National Water Quality Laboratory certification analyses of blank water are reported as raw results without rounding or censoring; analytical variability and calibration techniques can cause results to be negative or below long-term method detection levels (LT-MDLs). NWIS-I lot numbers are used for tracking. Abbreviations: $\mu \mathrm{g} / \mathrm{L}$, microgram per liter; emd, universal blank water from EMD Chemicals, Inc.; NWIS, National Water Information System; rcc, inorganic blank water from Ricca Chemical Company; *, value between the LT-MDL and laboratory reporting level (LRL); **, value above the LRL]

\begin{tabular}{|c|c|c|c|c|c|c|c|c|c|c|}
\hline $\begin{array}{c}\text { NWIS-I } \\
\text { lot } \\
\text { number }\end{array}$ & $\begin{array}{c}\text { Vendor lot } \\
\text { number }\end{array}$ & $\begin{array}{c}\text { Period of } \\
\text { availability }\end{array}$ & $\begin{array}{c}\text { Analysis } \\
\text { date }\end{array}$ & $\begin{array}{l}\text { Silver } \\
\text { ( } \mu \mathrm{g} / \mathrm{L})\end{array}$ & $\begin{array}{c}\text { Strontium } \\
(\mu \mathrm{g} / \mathrm{L})\end{array}$ & $\begin{array}{c}\text { Thallium } \\
\text { ( } \mu \mathrm{g} / \mathrm{L})\end{array}$ & $\begin{array}{c}\text { Tungsten } \\
\text { ( } \mu \mathrm{g} / \mathrm{L})\end{array}$ & $\begin{array}{l}\text { Uranium } \\
\text { ( } \mu \mathrm{g} / \mathrm{L})\end{array}$ & $\begin{array}{l}\text { Vanadium } \\
(\mu \mathrm{g} / \mathrm{L})\end{array}$ & $\begin{array}{l}\text { Zinc } \\
(\mu \mathrm{g} / \mathrm{L})\end{array}$ \\
\hline 80301 & emd 43084 & $02 / 31 / 2003-03 / 31 / 2005$ & $05 / 2003$ & -0.035 & 0.019 & 0.000 & na & 0.000 & 0.013 & 0.079 \\
\hline 80401 & emd 44048 & $06 / 30 / 2004-06 / 30 / 2005$ & $06 / 2004$ & -0.002 & 0.020 & -0.001 & na & 0.001 & 0.061 & -0.194 \\
\hline 80402 & rcc 1406619 & $03 / 31 / 2005-06 / 30 / 2006$ & $03 / 2005$ & -0.008 & 0.005 & 0.003 & na & -0.001 & 0.007 & $* * 0.803$ \\
\hline \multirow{5}{*}{80501} & & (GAMA only used it & $04 / 2006$ & 0.000 & $* * 1.235$ & -0.001 & -0.010 & 0.002 & 0.010 & 0.070 \\
\hline & & through $02 / 28 / 2006$ ) & $04 / 2006$ & 0.007 & $* * 1.428$ & -0.001 & -0.010 & 0.003 & 0.010 & 0.110 \\
\hline & & & $04 / 2006$ & 0.003 & $* * 0.647$ & -0.001 & -0.010 & 0.002 & -0.010 & 0.130 \\
\hline & & & $04 / 2006$ & 0.004 & 0.166 & -0.001 & -0.010 & 0.001 & -0.020 & 0.020 \\
\hline & & & $04 / 2006$ & 0.001 & $* 0.257$ & -0.001 & -0.020 & 0.000 & -0.020 & 0.050 \\
\hline \multirow{9}{*}{80502} & & & $03 / 2005$ & -0.006 & 0.059 & -0.011 & na & -0.016 & 0.029 & 0.243 \\
\hline & & & $03 / 2005$ & -0.007 & 0.028 & -0.012 & na & -0.016 & 0.019 & 0.133 \\
\hline & & & 03/2005 & -0.004 & 0.086 & -0.012 & na & -0.016 & 0.017 & ** 0.997 \\
\hline & & & $06 / 2005$ & 0.003 & 0.034 & -0.001 & na & 0.007 & $* 0.073$ & 0.073 \\
\hline & & & $06 / 2005$ & 0.004 & 0.033 & -0.003 & na & 0.003 & -0.006 & 0.076 \\
\hline & & & $06 / 2005$ & 0.025 & $* * 0.443$ & 0.001 & na & $* 0.02$ & 0.005 & 0.128 \\
\hline & & & $06 / 2005$ & 0.013 & 0.030 & 0.004 & na & 0.005 & -0.082 & 0.252 \\
\hline & & & $04 / 2006$ & 0.016 & 0.024 & 0.000 & na & 0.001 & -0.030 & 0.076 \\
\hline & & & $04 / 2006$ & 0.009 & 0.026 & -0.001 & na & 0.001 & -0.030 & 0.173 \\
\hline \multirow[t]{2}{*}{80602} & rec 1604792 & 06/30/2006-06/30/2007 & $06 / 2006$ & 0.000 & 0.016 & 0.002 & na & 0.000 & 0.010 & 0.157 \\
\hline & & & $06 / 2006$ & 0.000 & 0.009 & -0.002 & na & 0.002 & -0.010 & 0.083 \\
\hline \multirow[t]{2}{*}{80605} & rcc 1608581 & 09/30/2006-09/30/2007 & $08 / 2006$ & 0.000 & 0.090 & -0.010 & 0.000 & 0.000 & 0.000 & -0.050 \\
\hline & & & $10 / 2007$ & 0.002 & 0.050 & 0.003 & 0.002 & 0.001 & 0.006 & -0.146 \\
\hline \multirow[t]{2}{*}{80701} & rec 1701814 & 02/28/2007-02/29/2008 & $02 / 2007$ & -0.020 & 0.000 & 0.000 & 0.000 & 0.000 & 0.000 & $* 0.340$ \\
\hline & & & $10 / 2007$ & 0.002 & 0.026 & 0.005 & 0.003 & 0.002 & 0.011 & 0.154 \\
\hline \multirow[t]{4}{*}{80703} & rcc 1709365 & 09/30/2007-09/30/2008 & 09/2007 & 0.002 & 0.051 & -0.001 & 0.001 & 0.000 & 0.000 & $* 0.301$ \\
\hline & & (GAMA only used it & $09 / 2007$ & -0.001 & 0.027 & -0.002 & 0.001 & 0.000 & -0.001 & 0.095 \\
\hline & & through 10/31/2007) & $09 / 2007$ & -0.001 & 0.025 & -0.002 & 0.000 & 0.000 & -0.001 & -0.044 \\
\hline & & & $09 / 2007$ & 0.003 & 0.037 & -0.002 & 0.000 & 0.000 & -0.001 & $* 0.595$ \\
\hline \multirow[t]{4}{*}{80704} & $\operatorname{rcc} 4710088$ & $10 / 31 / 2007-10 / 31 / 2008$ & $10 / 2007$ & 0.000 & 0.009 & 0.000 & 0.000 & 0.000 & 0.000 & 0.055 \\
\hline & & & $10 / 2007$ & 0.000 & 0.009 & 0.000 & 0.001 & 0.000 & 0.000 & 0.119 \\
\hline & & & $10 / 2007$ & 0.015 & 0.010 & 0.001 & 0.001 & 0.001 & 0.001 & 0.455 \\
\hline & & & $10 / 2007$ & 0.001 & 0.034 & 0.002 & 0.000 & 0.001 & 0.001 & $* 1.130$ \\
\hline
\end{tabular}




\section{Glossary of Terms}

associated blank A blank that was collected and analyzed under conditions that are comparable to those under which the corresponding environmental samples were collected and analyzed.

binomial distribution function This function can be used to determine the conditions under which a specified probability and confidence of success or failure are met. It is sometimes called the "binomial cumulative distribution" or "binomial probability distribution." This nonparametric approach uses the number of blanks or samples, rather than actual data, to provide the rank of the data value at which the desired conditions are met. For this study, the binomial distribution function was determined using the BINOMDIST function in Microsoft Excel.

blank An artificial sample, usually blank water, that is free of the analytes of interest.

field blank A blank that is collected in the field in the same manner as the environmental samples and subjected to all aspects of sample collection.

laboratory blank A blank prepared in the laboratory that undergoes all sample preparation and analysis steps used for the environmental samples; this type of blank can be used to determine the laboratory response to a sample that does not contain the analytes of interest or to determine the background response for analytical methods that have a background response.

source-solution blank A blank consisting of freshly opened blank water (source solution) transferred directly into the sample vials or bottles under clean conditions in the field, and sent directly to a laboratory to confirm that it is free of the analytes of interest.

contaminant A substance that is either present in an environment where it does not belong or is present at levels that might harm humans or the environment.

contamination bias Bias (error) in a measurement, usually in the positive direction, because of the unwanted or unintended addition of a contaminant that either was not present in the environmental matrix being sampled or that was present at a level lower than that measured.

data verification An evaluation of data from field measurements or laboratory analyses that includes comparing the quality-control results to predetermined quality-control criteria, checking the environmental data for completeness and correctness, and taking appropriate actions to flag or qualify data that are of questionable or reduced quality.

extrinsic contamination Contamination of an environmental sample or quality-control sample that originates from a process or source that is external to the medium being sampled and therefore is not representative of the medium being sampled.

laboratory reporting level (LRL) The LRL is usually set equal to twice the most recently determined LT-MDL. The LRL controls false negative error; the probability of falsely reporting a nondetection for a sample that contains an analyte at a concentration equal to or greater that the LRL is predicted to be less than or equal to 1 percent. Results for an analyte not detected should be reported as "less than" $(<)$ the LRL. The NWQL continuously collects QC data for analytical methods to determine LT-MDLs and establish LRLs. These values are re-evaluated annually and therefore may change.

long-term method detection level (LT-MDL) A detection level derived by determining the standard deviation of a minimum of 24 MDL blank or spiked samples analyzed over an extended period of time. LT-MDL data are collected continuously throughout the year to assess variations in method performance. The chance of falsely reporting a concentration at or greater than the LT-MDL for a sample that did not contain the analyte is predicted to be less than or equal to 1 percent.

method detection limit (MDL) The minimum concentration of a substance that can be measured and reported with 99-percent confidence that the analyte concentration is greater than zero. It is determined by analyzing one or more samples in a given matrix containing known concentrations of the analyte (U.S. Environmental Protection Agency, 1997). At the MDL concentration, the risk of a false positive is predicted to be less than or equal to 1 percent. 
inorganic blank water (IBW) Blank water that is intended to be free of inorganic analytes of interest, usually designated as "ASTM Type I" water. Inorganic blank water that is purchased through USGS One-Stop Shopping is supplied through the NWQL and undergoes quality-assurance testing; test results and certificates of analysis are available at $h t t p: / /$ wwwnwql.cr.usgs.gov/USGS/IBW/ibw.html. Before June 2006, universal blank water (UBW) was available for use as inorganic blank water.

study reporting level (SRL) A censoring level that is higher than the laboratory detection or reporting level (for example, the LT-MDL). It is established for a particular study on the basis of field and (or) laboratory quality-control results, usually to minimize reporting of false positives. For this study, numerical results that are below the study reporting level are reported as less than or equal to $(\leq)$ the measured concentration. For example, for an analyte with an LT-MDL of $2 \mu \mathrm{g} / \mathrm{L}$ and an SRL of $6 \mu \mathrm{g} / \mathrm{L}$, a result of $3 \mu \mathrm{g} / \mathrm{L}$ would be reported as $\leq 3 \mu \mathrm{g} / \mathrm{L}$, meaning that the result could be less than or equal to $3 \mu \mathrm{g} / \mathrm{L}$. universal blank water (UBW) Discontinued after June 2006, this blank water was intended to be free of organic and inorganic analytes of interest. UBW was pesticide-grade water that was purged with ultra-high purity nitrogen gas $\left(\mathrm{N}_{2}\right)$ to remove any volatile organic carbons that might be present, and then analyzed by the NWQL for nutrients, major ions, and trace elements. During late 2005 to early 2006, concerns arose about inorganic contaminants thought to be leaching from the glass bottles (notably aluminum, boron, and silica) to a degree that was not observed for IBW; therefore, the NWQL discontinued preparation and sale of UBW. 
Manuscript approved for publication, September 29, 2009 Prepared by the USGS Enterprise Publishing Network, Publishing Service Center, Sacramento, California

For more information concerning the research in this report, contact the California Water Science Center Director,

U.S. Geological Survey, 6000 J Street

Sacramento, California 95819

http://ca.water.usgs.gov 


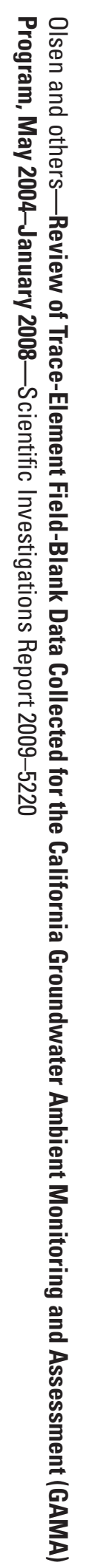

8 Printed on recycled paper 